
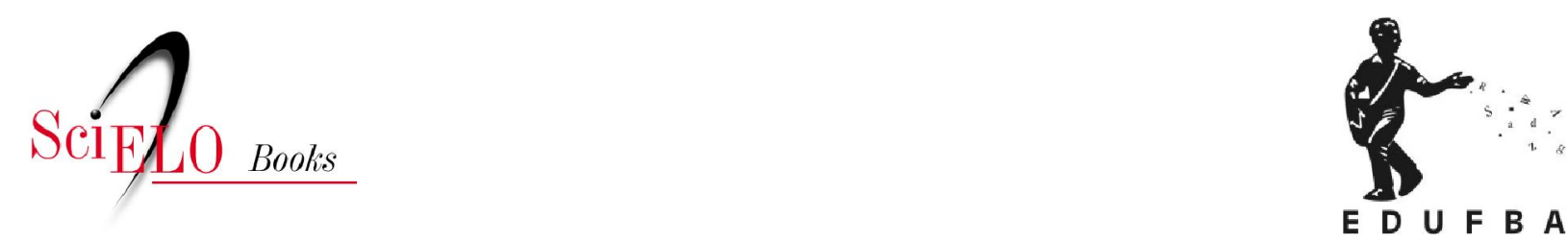

\title{
Cultura negra em tempos pós-modernos
}

\author{
Marco Aurélio Luz
}

LUZ, MA. Cultura negra em tempos pós-modernos [online]. 3rd ed. Salvador: EDUFBA, 2008. 181 p. ISBN 978-85-232-0906-3. Available from SciELO Books $<$ http://books.scielo.org $>$.

\section{(c) $(9)$}

All the contents of this chapter, except where otherwise noted, is licensed under a Creative Commons Attribution-Non Commercial-ShareAlike 3.0 Unported.

Todo o conteúdo deste capítulo, exceto quando houver ressalva, é publicado sob a licença Creative Commons Atribuição - Uso Não Comercial - Partilha nos Mesmos Termos 3.0 Não adaptada.

Todo el contenido de este capítulo, excepto donde se indique lo contrario, está bajo licencia de la licencia Creative Commons Reconocimento-NoComercial-CompartirIgual 3.0 Unported. 


\section{Cultura Negra em Tempos Pós-modernos}




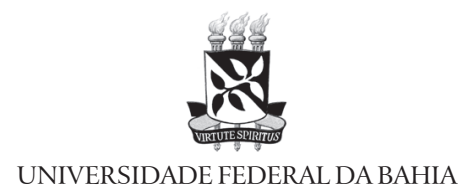

Reitor

NAOMAR DE ALMEIDA FILHO

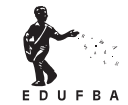

EDITORADA UFBA

Diretora

FLÁVIA M. GARCIA ROSA

Conselho Editorial

Antônio Virgílio Bittencourt Bastos

Arivaldo Leão de Amorim

Aurino Ribeiro Filho

Cid Seixas Fraga Filho

Fernando da Rocha Peres

Mirella Márcia Longo Vieira Lima

\section{Suplentes}

Cecília Maria Bacelar Sardenberg

João Augusto de Lima Rocha

Leda Maria Muhana Iannitelli

Maria Vidal de Negreiros Camargo Naomar Monteiro de Almeida Filho

Nelson Fernandes de Oliveira 
Marco Aurélio Luz

\section{Cultura Negra em Tempos Pós-modernos}

$3^{a}$ edição 
(C) 2002 by Marco Aurélio Luz

Direitos para esta edição, cedidos à

Editora da Universidade Federal da Bahia.

Feito o depósito legal.

\section{Capa e projeto gráfico \\ Rogério S.Amaral}

Editoração eletrônica

Rogério S. Amaral

Josias Almeida Jr.

\section{Revisão de Linguagem e Editorial \\ Tania de Aragão Bezerra \\ Magel Castilho de Carvalho}

Luz, Marco Aurélio, 1944-

Cultura negra em tempos pós-modernos / Marco Aurélio Luz. - 3. ed.. - Salvador :

EDUFBA, 2008.

181 p. : il.

Inclui bibliografia.

ISBN 978-85-232-0531-7

1. Negros - Condições sociais. 2. Negros - Brasil - Condições sociais. 3. Brasil -

Civilização - Influências africanas. 4. Negros - Religião e cultura. 5. Democracia -

Aspectos sociais. 6. Negros no Brasil. I. Título.

CDD - 305.896081

EDUFBA

Rua Barão de Jeremoabo, s/n ${ }^{\circ}$

Campus Universitário - Ondina

40.170-115 - Salvador - Bahia-Brasil

Tel/Fax: (71)3283-6160/6777

www.edufba.ufba.br edufba@ufba.br 
Aos meus pais Waldyr e Célia

Aos meus filhos Gabriela, Mariana, Marcos, Maurício e Marcelo. 



\section{SUMÁRIO}

APRESENTAÇÃO da $3^{\text {a }}$ Edição $\quad 09$

APRESENTAÇÃO da 2a Edição 11

Tranças, Redes e Sinergia

APRESENTAÇÃO da $1^{\text {a} E d i c ̧ a ̃ o ~}$

PARAGUAÇÚ-CARAMURU 17

DIVERSIDADE E CONFLITOS DE CIVILIZAÇÃO

MODERNIDADE:

Tarzan, O Homem-macaco

50 ANOS DA DECLARAÇÃO UNIVERSAL 65

DOS DIREITOS DO HOMEM

De que Homem?

IDI N'LA:BUNDA GRANDE GRANDE NBUNDA 71

SUBVERSÃO SILENCIOSA

O Desgaste do Poder Político na Pós-modernidade

PAINEL PLURALISTA

Pós-modernismo e Política

O SEGREDO E O SAGRADO 85

ARKHÉ E AXEXÉ $\quad 89$

Linguagem e Identidade

IPORI E ELEDÁ

A propósito da Polêmica sobre o Dique do Tororó 
O LUGAR DO POLÍTICO NA TRADIÇÃO NAGÔ 101

ANCESTRALIDADE E SIMBOLOGIA: 107

25 anos do Ilê Asipá

A ARTE DE MESTRE DIDI 113

OPÔ BABA N'LAWA 117

BAIANA 123

TEMPOS ECUMÊNICOS EM BLACK OR WHITE 127

MUTANTE EGÍPICIO 131

Remember the Time, TV de Cor

DO TRONCO AO TAMBOR DO OLODUM 135

COM MICHAEL JACKSON

BURN BABY BURN 139

O Fogo da justiça em Los Angeles

DEMOCRACIA E DIVERSIDADE HUMANA 143

NA DIVERSIDADE HUMANA 147

TODO SANGUE É VERMELHO

PINDORAMA, BRASIL, ILÊ AXÉ 151

500 Anos Depois, a Terra está em Perigo

O LÚDICO E O SAGRADO 157

A Propósito do Dream Team

A PASSOS DE POMBO, O JOGO DA LIBERDADE 163

A Coexistência da Diversidade Humana

MUHAMED ALI: A BORBOLETA E A ABELHA 167

IMAGINÁRIO PÓS- MODERNO 171

Garrincha e a Alma do Botafogo

O ÔNIBUS E O ATABAQUE

para além de "raça" e "classe"

INDICAÇÕES BIBLIOGRÁFICAS 179

DADOS DO AUTOR 181 


\section{APRESENTAÇÃO da 3a Edição}

Nessa terceira edição observamos a continuidade do "esprit du temps" o espírito do tempo como disse Michel Maffesoli, em direção pendular à pós modernidade. Percebemos que algumas crises da era moderna resultantes do imperialismo estão mais à mostra como a destruição da natureza, as guerras sem fim, a acumulação incessante de capital resultante das explorações e expropriações, a continuidade dos Estados totalizantes e europocêntricos... Ao mesmo tempo, porém, que há reações de diversos matizes,sopram ventos de novas idéias de tentativas de regeneração do planeta em novas bases de valores pós- modernos. Dentre elas a preservação da natureza e uma nova ética de respeito ao direito a existência de todos os povos,...

Acrescentamos nessa edição novos capítulos abordando de modo mais direto aspectos da pós modernidade em nossa terra, em especial no que se refere à cultura africano - brasileira.

O primeiro capítulo a abrir o livro,trata de uma viagem pelo imaginário brasileiro tomando como referencia o conflito de valores de civilizações diferentes. O célebre encontro ou desencontro original de Paraguaçu com Diogo Álvares o Caramuru, apresentados no imaginário ideológico como uma metáfora do surgimento de nossa nação em terras da Bahia.Todavia nessa viagem destacamos aspectos do processo histórico de afirmação existencial da comunalidade africano brasileira.

Outro capítulo "Idi Nla, Bunda Grande, Grande Nbunda" se refere às dificuldades de convivência com a alteridade dos povos constituintes da humanidade a partir do imaginário que alimenta o racismo. Tem como referência o triste episódio ocorrido no fim do séc.XIX até os dias atuais, da chamada "Venus Hotentote", e procura aprofundar a elaboração da fonte do recalque que levou franceses e outros europeus a cometerem a ignomínia só retratada recentemente em 2002. 
O capítulo "Ancestralidade e Simbologia" se refere à linguagem própria e aos valores das comunidades de tradição ao culto aos ancestrais masculinos, os Baba Egun,onde procuramos realçar a linguagem estética que magnifica o sagrado.

O capítulo "Baiana" tenta debater o processo de conflito dos valores e de linguagem do chamado mundo do samba, especificamente o desfile das escolas de samba do Rio de Janeiro em contato com a indústria do turismo e a cultura do espetáculo dos mass mídia.

Outro capítulo presta homenagem a Garrincha como um símbolo dos valores pós- modernos no esporte, especialmente no futebol arte brasileiro em que foi um dos seus mais insignes representantes, não só por suas atuações em campo mas também na constituição dos fundamentos que combinam o prazer estético do lúdico com a alegria.

Por último, mas não menos importante, queremos destacar a colaboração inestimável de Narcimária Correia do Patrocínio Luz com quem conjuntamente realizamos muitos e distintos projetos dentre os quais essa terceira edição.

Marco Aurélio Luz

Lauro de Freitas, 03 de setembro de 2008 


\section{APRESENTAÇÃO da $2^{\text {a }}$ Edição \\ Tranças, Redes e Sinergia}

Nesta segunda edição de CULTURA NEGRA EM TEMPOS PÓSMODERNOS, acrescentamos vários capítulos e continuamos a adotar uma metodologia transdisciplinar e intercultural, pois nossas reflexões se situam nos interstícios entre dois ou três processos civilizatórios continentais, ou seja, da África, América e Europa que adquirem formas históricas de interações culturais contextuais próprias no Brasil.

Os tempos de agora são os mesmos da primeira edição, apenas se agudiza a trajetória de implosão do Estado moderno, e percebemos o quão trágico pode ser a passagem para a pós-modernidade, sobretudo no que se refere à expansão e ao grau de violência que se dissemina pela chamada globalização de um lado, e por outro, os esforços de elaboração e constituição de novas utopias que se inspiram no respeito à alteridade, enfim como anunciou um Congresso realizado na África, o direito à existência de todos os povos. ${ }^{I}$

Esse direito se assentará numa ética do futuro ${ }^{2}$ que permite termos esperanças em novos tempos mais harmônicos e pacíficos para a humanidade, percebida então como uma das espécies da natureza, e que sem essa percepção intrínseca do processo do existir pode deixar de constituir-se num elo desse mesmo processo.

Mantivemos a mesma estrutura anterior, de tranças, redes e sinergia para a constituição dos capítulos, que são na verdade combinação de artigos e ensaios que visam a dar uma percepção do contexto sóciocultural de nossa atualidade, marcada ainda, de um lado, pela resistência dos valores da modernidade em processo de implosão; de outro, pela combinação do processo civilizatório afro-brasileiro e afro-americano, em geral a partir da reflexão sobre determinados tópicos exemplares extraídos de nosso cotidiano.

Assim, esses tópicos são abordados pelo meu conhecimento acumulado, tanto por minha formação acadêmica interdisciplinar, ou seja, o manejo da psicanálise (sociopsicanálise), ciência da História (teoria dos discursos), 
Sociologia(análise institucional), Antropologia e teoria da Comunicação (universo simbólico), Filosofia, etc., como pela minha trajetória de vida que inclui fundamentalmente minha integração na comunalidade africanobrasileira, que abrange outras formas de comunicação, percepção e conhecimento que alguém denominou de emocional lúcido ${ }^{3}$, para além da estrutura do manto de ferro da pedagogia da escrita, imposta pela sedução do mundo virtual globalizante.

Quero destacar que o capítulo que se refere à Sócio-Psicanálise de um Herói da Modernidade possui uma gama de ilações que visam a compreender a construção tipológica do "homem moderno", que hoje se desdobra nos comportamentos recalcados da virtualidade e, sobretudo da guerra à distância, a destruição do outro; e, portanto do Outro, o Criador e a riqueza da criação, a diversidade.

Gostaria de registrar que a maioria dos capítulos teve sua publicação no Caderno Cultural do Jornal A Tarde e, mais uma vez, quero agradecer àqueles que colaboraram para a concretização deste livro, especialmente aos amigos e irmãos do Ilê Asipá, INTECAB - Instituto Nacional da Tradição e Cultura Afro-Brasileira e a SECNEB - Sociedade de Estudos das Culturas e da Cultura Negra no Brasil.

Por fim, sublinho que acrescentei na dedicatória o nome de Marcelo do Patrocínio Luz, que chegou a esse mundo depois da primeira edição.

\section{Marco Aurélio Luz}

Lauro de Freitas, 18 de março de 2002.

\footnotetext{
Notas

${ }^{1}$ Conceituação que emerge durante o Fórum Internacional Direitos do Homem e Diversidade Humana organizado pela Sociedade de Estudos das Culturas e da Cultura Negra no Brasil - SECNEB.

2 Conceito utilizado inicialmente por Muniz Sodré no Encontro Internacional Diversidade Humana, Desafio Planetário , realizado em Salvador - Bahia, em 1994, organizado pela Sociedade de Estudos das Culturas e da Cultura Negra no Brasil - SECNEB.

${ }^{3}$ Santos, Elbein Juana. O Emocional Lúcido, Salvador: Edições SECNEB, 2002.
} 


\section{APRESENTAÇÃO da $l^{\mathrm{a}}$ Edição}

Esse livro resulta das experiências vividas durante e após a realização do curso de pós-doutorado (1990-1991), em Paris, no Centre D’Études sur l'Actuel et le Quotidien, Paris V, Sorbonne, dirigido por Michel Maffesoli. Pouco antes de meu retorno ao Brasil, proferi uma palestra no auditório Émile Durkheim, na Sorbonne, onde o fundador da Sociologia lecionava seus cursos, e em que afirmava ser a religião, os valores sagrados, os princípios da socialidade; o desejo de estar junto, o compartilhar paixões, sentimentos e emoções comuns, re-ligare, pulsão da humanidade. Quando cheguei de volta à Bahia, deixando para trás aquela cidade bela de se ver, organizada pelos mais tradicionais padrões cartesianos e positivistas, em que se tenta recortar o tempo e o espaço de modo cronométrico e geométrico procurando-se controlar a vida, aqui era a época do S. João. O povo em volta da fogueira, a vida sócio-comunitária transbordando pelo prazer das alianças forjadas na cumplicidade de uma temporalidade e espacialidade marcadas pelo imaginário lúdico-sagrado. No Ilê Asipá, terreiro dedicado ao culto dos ancestrais masculinos, ocorriam os preparativos do festival de Babá Alapala, um dos Eguns mais antigos e importantes, relacionado com o imaginário do fogo, princípio da vida social: quando vivente foi um filho de Xangô.

No dia 23 de junho, ao cair da tarde, em meio ao crepitar da fogueira elevando fagulhas, a comunidade reunida cantava com emoção e paixão chamando os Eguns para a festa.

A noite iluminada pelas chamas da lenha crepitando adornavam as evoluções da dança de Babá no rítmo dos atabaques da orquestra ritual.

Mais tarde, já sentado no Ilê nla, a casa grande das festas públicas, Babá Akyola chamou-me por meu título africano-brasileiro. Aproximei-me saudando-o respeitosamente, aí perguntou-me como estava passando, por minha família, me deu axé, mandou que eu cantasse para ele, cantei acompanhado pelo coro dos irmãos e irmãs todos irmanados pela atmosfera 
sagrada numa mesma pulsação, por fim, mandou-me dançar... Estava reintegrado à vida comunal.

É em meio ao ir e vir pelas instituições que concentram o saber-poder do Estado, sobretudo a Universidade, e as que concentram o saber-poder das comunidades africano-brasileiras, que nossa percepção se lança na tentativa de compreender as dimensões mais encobertas dos fatos quotidianos que marcam com intensidade nosso tempo, tempo pós-moderno.

Cultura Negra em Tempos Pós-Modernos aborda o significado dos processos culturais dinâmicos das tradições africanas nas Américas no momento atual, caracterizado pela crise e implosão do Estado-nação, positivista, produtivista moderno, e pela emergência do imaginário que alimenta a bacia semântica de novos valores que promovem as alianças comunitárias constituídas à sua margem em crescente expansão.

Entre o Estado-nação, europocêntrico e totalizante de um lado e a rede comunitária à sua margem de outro, existem os interstícios onde interagem linguagens, valores e identidades, caracterizando os contextos sociais como eminentemente pluri-sócio-culturais.

A emergência de pulsões sociais com suas nuances e matizes próprios, surgindo da vida comunitária e deslizando pelas rachaduras em meio a implosão do Estado moderno caracterizam o que se chama de pós-modernidade.

Uma das características da pós-modernidade é o valor da busca da satisfação do desejo de estar-junto, a pulsão de sociabilidade, que decorre da procura em aplacar a angústia existencial do mistério da origem, do devir e do imponderável e que se alimenta das elaborações sobre o existir.

Neste contexto, a produção social está sobredeterminada pelas pulsões espirituais que constituem a sociabilidade.

Diferente é o contexto do Estado moderno em crise, exatamente porque silencia e recalca os valores sagrados e coloca os princípios da produção como capazes de satisfazer por si só as necessidades e vicissitudes humanas, promovendo, por outro lado, a busca do aumento incessante da produtividade, gerando a competição entre os Estados-nações em luta por hegemonias de mercado e supremacias político-econômicas.

Conseqüência da predominância desses valores constituintes do Estado moderno tem sido a ocorrência trágica de processos de genocídios, de destruição da natureza, guerras, fomes, corrupção, e mesmo a ameaça de destruição do planeta, estabelecendo assim seu próprio limite...

Maffesoli caracteriza esse contexto atual como um momento do movimento pendular do esprit du temps, espírito do tempo, que oscila entre princípios prometéicos e dionisíacos.

Procurar destacar as características desse processo a partir do nosso quotidiano, abordando fatos como sintomas sócio-culturais, realçando a presença e significado da cultura negra na atualidade é o principal objetivo 
deste livro. Aproveito esta ocasião para agradecer a todos que de certa forma colaboraram na concretização deste livro, destacando Narcimária C. do Patrocínio Luz, Juana Elbein dos Santos, Deoscoredes M. dos Santos, Michel Maffesoli, Muniz Sodré e Florisvaldo Mattos, responsável pelo Caderno Cultural de A TARDE, onde foram publicados alguns dos trabalhos ora inseridos, e ainda aos colegas e amigos da Tribuna da Bahia, FACED-UFBA, SECNEB e INTECAB.

Marco Aurélio Luz

Lauro de Freitas, agosto 1992. 



\section{PARAGUAÇÚ-CARAMURU DIVERSIDADE E CONFLITOS DE CIVILIZAÇÃO}

A pós-modernidade começa em Hiroshima.

(Emílo Rodrigué)

Tupy or not Tupy,eis a questão.

(Oswald de Andrade)

\section{Introdução}

Um pássaro descendente daquele que fora atingido nos inícios do século XVI por Diogo Álvares Correia conhecido como Caramuru me contou: Paraguaçu é água em quantidade, rio de vida. Já Caramuru é pau de fogo, arma destrutiva, mortífera, perigo e ameaça de morte...

Mãe Aninha que foi a fundadora e primeira Iyalorixá do Ilê Axé Opô Afonjá fundado em 1910, ouvi dizer, transmitia a nossa gente que deveriam ser como o bambu que ante o vendaval enverga para não quebrar. Ela também foi priora da Irmandade de Nossa Senhora do Rosário dos Pretos e ensinava ainda, que por outro lado, não se pode muito abaixar, porque quando muito se abaixa alguma coisa aparece.

Ela viveu e alcançou o tempo do aguçamento da modernidade no Brasil, o período do início da industrialização, a ditadura de Vargas. Diante dessa política do Estado Novo tentando impor os valores imperialistas, inicialmente ainda de projeção britânica, a comunidade afro-brasileira teve que "caçar jeito de viver", pois a perseguição as suas instituições foi brava, só para lembrar, foi o tempo do delegado Pedrito Gordo na Bahia, famoso por perseguir e invadir os "terreiros de candomblé".

A capoeira também foi muito perseguida, e sobre o nome do Mestre Bimba recai a legenda de negociação e criação de uma linguagem que permitiu 
envergar e não quebrar, mantendo a ginga na tal capoeira de "academia" a chamada Regional, mas que de certa forma escudou e permitiu por outro lado à continuidade da capoeira Angola, tradicional.

Também o samba teve de se adaptar, surgiram escolas e acadêmicos, sambas enredos de motivos ufanistas obrigatórios com desfiles e concepções operísticas. Mas dessa forma por outro lado, também continuaram as formas tradicionais do samba de roda, etc.

Por falar em acadêmicos, na Sociologia foi predominando nos estudos "sobre o negro" da chamada "Escola Paulista", a obra A Integração do Negro na Sociedade de Classes de Florestan Fernandes, o emblema maior de uma determinada problemática. Problemática que de certa forma impede a percepção da dinâmica da civilização africana nas Américas, delimitando o espaço só para a "luta de classes".

Era o contexto em que o compositor Wilson Batista no Rio de Janeiro deixava o lenço no pescoço e a navalha, aceitando os "conselhos" de Noel, e anunciava, “... o bonde de São Januário leva mais um operário, sou eu que vou trabalhar...".

O bonde, símbolo da modernidade imperialista britânica se impondo nas cidades da energia elétrica e outros confortos, da mesma forma que o trem que se adentrava pelo interior provocando a recusa de Zé Limeira, "o cantado malhó que a Paraíba criou-lo"...

\section{Eu me chamo Zé Limeira. \\ Cantadô que tem ciúme \\ Brisa que sopra da serra \\ Fera que chega do cume \\ Brigada de só de peixeira \\ Mijo de moça solteira \\ Faca de primeiro gume.}

Foi certa vez na fazenda de Raimundo Rolim, próximo aos trilhos da Greet Western, que conforme narra Orlando Tejo , Zé Limeira tomou um grande susto:

Eu sou Zé Limeira, caboclo do mato

Capando carneiro no cerdo do bode

Não gosto de feme que vai no pagode

O gato fareja no rastro do rato

Carcaça de besta, sovaco de pato

Jumento, raposa,canção e preá

Sertão, Pernambuco, Sergipe e Pará

Dom Pedro Segundo de Sela e Sertão

Cantando galope na beira do má. 
Enquanto versejava no desafio com Sobrinho de súbito um som estranho sufocou a voz das violas. Era o que Limeira chamava de "grito de Satanás", o apito do trem de ferro...

Toda essa revolução da modernidade, com sua política de embranquecimento, seu positivismo evolucionista e etnocêntrico promove a necessidade de uma sujeição que tem como contrapartida à recusa a essa "ordem e progresso"...

Ora bolas/ não me amole/ com esse papo de emprego/ não tá vendo/ não tô nessa/ o que eu quero é sossego....Eu quero sossego!

A recusa do "síndico" Tim Maia com seu vozeirão ecoa pelos sete mares da black music.

Mas a recusa, já vimos tem de ter swing suficiente para processar-se por universos diferentes sempre mantendo a essência da origem.

A legenda de Besouro Cordão de Ouro um dos mais famosos da capoeira do Recôncavo demonstrava a inevitável estratégia de ter que se saber usar as armas dos adversários sob pena de sucumbir a elas.

Conta-se que procurando proteção de um coronel, Besouro foi traído pelo bilhete que este lhe entregara para apresentá-lo à pessoa que deveria protegê-lo. Na verdade, o bilhete instruía para a execução de sua morte, que somente a faca de tiririca poderia realizar. Sem saber ler, ele entregou ao executor a ordem escrita de sua própria hora.

\section{Entra em beco}

Sai em beco

É que anuncia o caminhar do afoxé Pae Burocô, fundado por Mestre Didi. Nesses becos da vida urbanizada, Mãe Aninha, Iyalorixá Oba Biyi, em 1937, aceitou o convite de Edson Carneiro e participou do II $^{\circ}$ Congresso Afro-Brasileiro em Salvador.

Essa participação, com uma comunicação sobre culinária litúrgica, marca a necessidade de uma estratégia de luta de afirmação existencial comunitária no terreno das instituições acadêmicas que até então alimentavam a "Razão de Estado", dando foro de cientificidade as ideologias que sustentam ações de discriminação e preconceito.

Para tanto, a Iyá Oba Biyi indicou um caminho: "de anel no dedo e aos pés de Xangô"; este desafio que estamos procurando desenvolver, desde os espaços ininterruptos que caracteriza a trajetória de seu neto mestre Didi.

Os caminhos estabelecidos por ele se caracterizavam pela criação e fundação de diversas instituições e recriações de linguagens sustentadas pelo movimento dialético "da porteira pra dentro da porteira pra fora" que sua mãe a Iyalorixá Oxum Muiwá, Mãe Senhora se referiu quando na direção da comunidade Ilê Axé Opô Afonjá. 
Mestre Didi fundou em 1940 o afoxé Pae Burokô, recriando linguagens, ocupando o espaço do carnaval, realizou o livro "YORUBÁ TAL QUAL SE FALA" divulgando a língua ancestral, publicou os contos por ele narrados, acervo de sabedorias e literatura da tradição, livros e ensaios comunitários, recriou esculturas baseadas nos valores estéticos da religião que o fizeram um sacerdote-artista de projeção internacional e finalmente fundou instituições de promoção científica e cultural, tudo isso visando a afirmação existencial, o direito a alteridade do povo nagô.

Por último e não menos importante destacamos sua atuação na experiência de educação pluricultural Mini Comunidade Oba Biyi, cujo currículo se assenta nos contos e nos autocoreográficos adaptados e realizados por ele, impulsos para uma nova pedagogia que contemple a linguagem e os valores afro-brasileiros, procurando integrar realmente nossa diversidade onde se afirma nossa identidade brasileira.

\section{Dimensão epistemológica dos obstáculos ideológicos e suas conseqüências: $O$ equívoco da noção de "raça"}

Será o conceito de "raça" racista?A indagação estava no ar naquele Fórum: Democracia e Diversidade Humana realizado pela SECNEB em 1990, e foi expressa pelo renomado psicanalista Emílio Rodrigué.

Evidentemente que sim, diria eu. Isto porque o conceito ou a noção ideológica tem por eficácia realizar a censura isto é, não permitir, através do recalque a percepção de verdades que possam causar distúrbios ou dores indesejáveis.

No âmbito das dimensões psico-sócio-culturais, ela funciona através do deslocamento, isto é, a noção de raça desvia da possibilidade de se entender o real fundamento das diversidades humanas, que possui na linguagem, nas diferentes formas de comunicação ou ainda de vinculação da sociabilidade caracterizada pelos valores, pelas instituições, territorialidade e temporalidade sua razão de ser.

Todo ser humano nasce e vive em sociedades. Desde a barriga da mãe o nascituro começa a receber sinais característicos e específicos do mundo em que viverá. Além de sua carga genética, o que nada tem haver com a noção de raça, como tantas vezes já demonstrou e comprovou a Biologia e a Genética, o nascituro herdará o contexto histórico e civilizatório de seus ancestrais.

São, portanto, os sistemas de civilizações que constituem a variedade de culturas que estruturam as identidades e alteridades humanas.

A noção ideológica de raça, funcional na problemática da discriminação, bloqueia a possibilidade de se perceber que o continente africano é formado por civilizações milenares que alimentaram as culturas da Afro-América. 
Atribui-se a alguns aspectos superficiais das diferenças físicas humanas todo aspecto da real diferença característica da humanidade que são seus variados fluxos civilizatórios.

Com isso destitui-se de valor, ou denega-se a alteridade dos valores culturais, elegendo-se apenas uma cultura, a do colonialismo do neocolonialismo e do imperialismo, como sendo o único caminho para a "integração das diferentes raças!!! nas relações de produção".

Está aí a razão da discriminação, a não aceitação da pluralidade cultural, na verdade, fonte da riqueza da humanidade.

Segue-se então variadas políticas equivocadas (?) de integração na "sociedade de classes" ou na valoração produtivista do imperialismo, interno e externo; a episteme unívoca do positivismo "ordem e progresso"...

\section{Raça e classe, duplo equívoco}

Não só a noção de "raça" é um obstáculo ideológico à percepção das alteridades, mas associada à noção ou conceito de classe empregada pelas ideologias marxistas formam uma verdadeira parede para o reconhecimento da pluralidade das sociabilidades.

Vista apenas pelo lado econômico a sociabilidade da tradição africana é lançada no limbo positivista do "comunismo primitivo", antecessor do "socialismo científico" ?!!!

Ainda percebido apenas pelo lado econômico nas Américas no processo de acumulação primitiva do capital está compreendido nas relações de produção do processo escravista apenas como escravo ou no máximo como "escravo fugido".

Enquadrado na grade da "luta de classes" bloqueia-se ou censura-se todo cabedal civilizatório africano, o fluxo contínuo de civilização que alimenta a sociabilidade, a comunalidade, a vinculação histórica e cultural.

\section{Os nagô e a morte}

Nesse contexto não se pode compreender as elaborações do existir que constituem as diferenças profundas de valores e de formas de vinculação e estar no mundo entre civilizações distintas, especialmente entre as de origem africana e as de origem européia.

No livro Os Nagô e a Morte, Juana Elbein dos Santos divulgou em termos eruditos os saberes da elaboração da existência da tradição yorubá no Brasil, mais conhecido como sistema cultural nagô.

No livro Agadá, Dinâmica da Civilização Africano-Brasileira, divulguei estudo comparativo entre o mundo dos valores africanos e o mundo dos valores europeus. 
A principal diferença está em que uma ordem de valores do mundo africano é capaz de absorver com uma certa harmonia as diferenças de cultura, civilização e, portanto, de identidades.

O ponto fundamental para nós está na aceitação e composição da presença da morte numa e noutra civilização.

Para além de toda complexidade litúrgica e estética fonte de sociabilidade e vinculação da comunalidade nagô, a sua filosofia, sua visão de mundo aponta para a compreensão de que vida e morte são uma única situação, Okan naa ni. Desde quando nascemos, já intuímos que vamos morrer e vamos para dar vez a outros.

Tendo um destino favorável de acordo aos princípios éticos, quando alguém "viaja" para o orun, cumprem-se os rituais de axexé, princípio dos princípios que se renovam, axé em constante circulação entre o aiyê e o orun.

Isso é motivo de alegria e satisfação, pois Morte Iku é um orixá, não pode deixar de cumprir sua obrigação de renovar as restituições de ipori, matéria de que são feitos os seres elaborados por Orixá n'la.

Já na cultura ocidental da modernidade, sendo a acumulação de capital o valor preeminente, a morte apresenta-se como verdadeira trágica contradição, pois não se pode levar o que se tem para o além.

Procura-se então desviar a presença da morte com fantasias de denegação da mesma, como costuma se apresentar nas criações imaginárias da cultura de massa. A crença onipotente de que a ciência superará todas as carências inclusive a do envelhecimento, verdadeira obsessão realizada pelas fantasias dos super-heróis.

Na fantasia dos super-heróis a morte só é perceptível pela presença do outro, desconhecido, ameaçador, portador do mal, paranóia crônica.

Para combatê-lo, só o poder de armas eficazes, o poder que advém da acumulação incessante de capital, de dinheiro, valor onipotente e onipresente na obssessividade paranóica da modernidade ocidental.

Mas voltemos à tradição religiosa nagô, ao culto aos ancestrais masculinos, o Baba-Egun, pai ancestral.

Quando vemos Baba, o vemos sempre em atitude livre, impávido, com gestos imponentes caracterizando seu mundo, o além como de ausência de carências. Isso é tendencialmente, pois terá como suporte de sua presença no aiyê, esse mundo dos viventes, seu povo, a humanidade inexoravelmente carente, precisando de seu axé, de seu poder espiritual delimitado pelo ixan vareta instrumento que os ojé, seus sacerdotes usam para distinguir e separar os dois mundos. Dois mundos separados e inseparáveis. A vida e a morte, Okan naa ni, são uma mesma coisa.

Conta-se que um dos ancestrais cultuados quando em vida, capturado pelos agentes escravistas negou-se a subir no navio da escravidão e foi executado. 
Essa lenda simboliza um profundo movimento de recusa e de absoluta afirmação existencial. Essa recusa acompanha todo processo de reposição da tradição africana nas Américas. Inúmeras táticas e estratégias de luta de afirmação existencial trouxeram até nós a riqueza de valores civilizatórios e a magnificência estética da linguagem da religião e da cultura, incomensurável saber...

\section{O rei está nu: Uma arqueologia da discriminação}

A tenacidade da luta dos africanos e seus descendentes pela liberdade e pela reconstituição do fluxo civilizatório da África nas Américas se expressou de forma contundente cotidianamente e em diversos momentos históricos.

Podemos mencionar o período de luta da renomada rainha Nzinga ou Ginga no Ndongo e seu desdobramento no quilombo do reino de Palmares de Ganga Zumba e Zumbi, nos séculos XVI e XVII, desestruturando o eixo mercantil-escravista Angola-Pernambuco da coroa portuguesa. Podemos ressaltar os quilombos e palenques espalhados pelas Américas, mas, especialmente, os que deram culminância à independência do Haiti, em 1804, e ainda as áreas libertas da Jamaica e outras regiões espalhadas das Américas.

Quando o Ougan Makhandal libertou-se das chamas de sua condenação, os africanos e seus descendentes inflamaram a ilha do Haiti com as luzes da libertação que culminaria na vitória do povo liderado por Dessalines derrotando as forças de Napoleão Bonaparte.

A perda da principal colônia da Companhia das Índias levou à uma transformação substancial nas formas de acumulação do capital financeiro e mercantil.

As lideranças do colonialismo, especialmente os ingleses, perceberam que o acúmulo da presença de africanos, com sua inquebrantável e constante resistência e luta de afirmação transformariam a América numa Afro-América, mais cedo ou mais tarde.

Estabeleceram então uma estratégia desdobrada em inúmeras táticas capazes de permitir com que eles perdessem os anéis, mas mantivessem os dedos, para continuarem puxando para si as "riquezas" do mundo colonial, fruto das conquistas e explorações, e causa de grandes sofrimentos e padecimentos que chegam até nossos dias.

Essa estratégia se caracterizou em procurar diminuir ao máximo a presença de africanos nas Américas, o que implicava em substituir o comércio escravista e a produção escravocrata como alvo do capital financeiro, que pouco a pouco irá se deslocar para novos âmbitos de aplicação, na manufatura e na industrialização. 


\section{Política de embranquecimento}

Desde a chegada de D.João VI ao Brasil, "escoltado" pela marinha britânica protegendo-o de Napoleão, que se intensificou a transferência da colônia portuguesa para se constituir em presença direta no mercado de hegemonia inglesa. Foi então estabelecido uma estratégia para realizar a "revolução burguesa" e a instauração do "trabalhador livre" de preferência branco.

Independência do Brasil de Portugal, fim do tráfico escravista, política de imigração de europeus, abolição do trabalho escravo, dívida externa ao capital financeiro internacional, instauração da república, foram alguns pontos dessa agenda que procurava constituir o neocolonialismo, isto é, colônias não só de exploração, mas de exploração e povoamento, que garantissem as conquistas imperialistas.

Para alimentar o projeto de europeização de bases industriais, juntamente com o "bota abaixo" das cidades do fim do período colonial, se procurava pouco a pouco botar abaixo não só edificações institucionais coloniais, mas também transformar o perfil da população, especialmente, a de aborígines, africanos e seus descendentes, para abrir espaço as novas relações de produção, tendo como agentes os imigrantes europeus.

Além de várias estratégias de caráter genocida, como a guerra do Paraguai, Canudos, a política de abandono sócio-econômico, etc, damos realce ao verdadeiro apartheid ideológico que se estabeleceu nas entranhas da revolução burguesa no Brasil.

$\mathrm{O}$ apartheid jurídico, político e econômico estabeleceu-se de forma virulenta nos EUA e na África do Sul. No Brasil, esse tipo de apartheid foi descartado para o uso, tão eficaz quanto das barreiras ideológicas que então alimentam as discriminações jurídico-políticas e econômicas.

As barreiras e representações ideológicas visam "desumanizar" os africanos e seus descendentes e deixá-los à mercê da manipulação das políticas genocidas.

Se tomarmos pontos de referência ilustrativa, podemos sublinhar a convite de Pedro II a vinda dos "intelectuais" franceses Gobinneau e Lapouge que instauram a representação da noção de "raça" "superior" e "inferior", e procuram animalizar e naturalizar os não brancos.

Depois seguiram-se as ideologias do recalque "psi", com Nina Rodrigues, com a teoria da "evolução filogenética da humanidade", e, mais recentemente, Arthur Ramos com a teoria das "culturas nevrosadas". Em outra vertente epistemológica o empirismo empregado por Edison Carneiro, dentre outros.

Todas essas ideologias teóricas alimentaram uma bacia semântica da discriminação que lança nos umbrais da criminalidade e da loucura, aqueles que se enquadram no perfil da representação do "criminoso nato" do jurista 
Lombroso, então sempre estudado e divulgado nas cadeiras de Direito Penal das faculdades de Direito.

$\mathrm{Na}$ instauração da República, o Estado laico dessacralizado se inspira na filosofia positivista de Auguste Comte, de onde se assenta o lema "ordem e progresso" de nossa bandeira.

A teoria dos três estágios sociais da humanidade discrimina os discursos, a linguagem e os valores, assegurando a ciência à serviço das tecnologias da sociedade burguesa, sua predominância hegemônica instauradora da razão e poder de Estado da industrialização.

Os discursos míticos da religião, as linguagens de valores sagradas da tradição africana são criticados e mesmo reprimidos e até perseguidos pela ação policial em nome da "civilização".

A partir dessas ideologias surgem a imagem dos estereótipos que denegam o direito a alteridade e mesmo o mesmo trará consigo o estigma "o preto de alma branca"???

\section{Constituição de estereótipos, o apartheid ideológico}

O apartheid ideológico genocida da política de embranquecimento possui uma estratégia definida em relação à constituição das representações dos estereótipos.

Todos visam em última instância atacar as fontes dos processos civilizatórios que asseguram orgulho e identidade especialmente os valores sagrados, assim também os valores de progenia e continuidade de existência.

Senão vejamos alguns desses estereótipos mais comuns. Uns atacam a mente a cabeça, e outros a genitália, respectivamente são eles o "nego feiticeiro", a "nega maluca", o "crioulo doido", "o negão com o pau desse tamanho", a "nega do balaio grande", "seu negro"... "cabelo ruim", "macaco", "a mulata que a cor não pega", etc.

O "nego feiticeiro" procura reduzir o integrante da comunalidade religiosa da tradição africano-brasileira a uma dimensão sinistra e perigosa, ao mesmo tempo, "primitiva", apequenando a religião toda sua riqueza de elaborações de mundo e estética litúrgica limitando-a a "feitiço"...

Esse preconceito procura instalar um apartheid ideológico, desqualificando a civilização africano-brasileira, que tem na religião a fonte de sua pulsão comunal e sua força imaginal que constituem as identidades próprias da tradição.

A "nega maluca" procura desqualificar não só a mulher negra, mas subrepticiamente ataca também a religião, desqualificando suas sacerdotisas. Esse estereótipo deriva basicamente dos primeiros arcabouços ideológicos "psi" que comparavam a manifestação de entidades religiosas do pantheon africanobrasileiro à crise psicomotora, sintoma de "histeria", "doença mental". 
Posteriormente a Nina Rodrigues, principal ideólogo dessa postulação discriminatória, surgiu também à reformulação "psi” de Arthur Ramos.

Baseado em um "mito africano" de um tal coronel Ellis servindo a rainha da Inglaterra na África e, divulgado por Nina Rodrigues, que fala da origem dos orixás como sendo fruto da perseguição de "Orugan" à sua mãe "Iemanjá", Arthur Ramos, psicanalista (?!), atribui ao complexo de Édipo um núcleo neurotizado da cultura afro-brasileira.

Nesse caso, conclui Arthur Ramos, não existiriam "raças inferiores ou superiores", mas sim, culturas adiantadas e atrasadas, ou melhor, nevrosadas. Para Arthur Ramos e outros higienistas, nas décadas de quarenta e cinqüenta do século XX, há que haver campanhas para "cientificamente", através da "educação", daí sua aliança com Anísio Teixeira, retirar os afro-descendentes da sua "prejudicial cultura neurotizada".

O "crioulo doido" surge para atacar o desdobramento estético da religião, ocupando as festas de largo e o carnaval constituindo o que convencionou chamar de mundo do samba.

Demonstrando a capacidade de realizar um dos maiores espetáculos da Terra, o desfile das escolas de samba, símbolo da identidade carioca, no entanto, vai sofrer a discriminação do intelectualóide estimulador do "voyeurismo" na imprensa, Stanislaw Ponte Preta, quem lançou o estereótipo do "samba do crioulo doido" na tentativa de desqualificar a pujante criatividade estética da comunalidade africano-brasileira.

Seguindo um caminho da imprensa, como aparelho ideológico de Estado a serviço do neocolonialismo, desde as incitações ao combate às casas religiosas e aos blocos e escolas de samba, Stanislaw Ponte Preta dentre outros, seguiram os passos de João do Rio, célebre detrator das "religiões do Rio de Janeiro" de origem africana.

Se esses estereótipos visavam desqualificar o pensamento, a linguagem e os valores africano-brasileiros, outros procuravam atacar a sexualidade, fonte de progênie.

No âmbito da política de branqueamento da população, os valores africanos de expansão de linhagens através das famílias extensivas e poligâmicas foram atacados não só pela anomia causada pela escravidão e explorações inauditas, mas também no terreno ideológico dos estereótipos.

Assim, a eficácia do estereótipo é tender a desqualificar os afrodescendentes de constituírem família; criarem seus filhos, expandir geneticamente seu povo.

Os estereótipos vão do "negão do pau desse tamanho"... personagem de piadas de mau gosto, até a "nega maluca solteira e tarada" das músicas de carnaval. 
O estereótipo de tentativa de animalização através do xingamento de "macaco" também é uma forma de censurar o processo primário, isto é, os valores da genitália como forma de expansão da humanidade.

Por outro lado, na cultura e religião africana, símbolos fálicos são elementos valorizados positivamente na tradição nagô.

No que se refere aos princípios masculinos, o opaxorô, o exin, o oxê, o ofá, o agadá, o xaxará, o ogó, etc. No que se refere aos símbolos femininos, o abebe, por excelência, e outras formas ovais, ventrais representações da capacidade de gestação, crescimento e criação.

Os estereótipos visam a baixar a auto-estima na constituição da identidade. A introjeção dos estereótipos envolve dois lados. Os que sofrerão do complexo de superioridade e os que sofrerão do complexo de inferioridade. Nos dois casos, é preciso superar a trama que estabelece as relações discriminatórias do que denominamos de apartheid ideológico.

A principal coluna sustentadora da identidade é a cultura, a linguagem e os valores que alimentam a inserção em determinadas dinâmicas de sociabilidade ou pulsão comunal.

Nas sociedades tradicionais negro-africanas e na comunalidade afrobrasileira, a religião ocupa o eixo central, fonte originária das culturas e da civilização.

Essa riqueza da humanidade é atacada basicamente pelos estereótipos do genocídio e do apartheid ideológico.

Devemos ir nessa direção, para percebermos que quando um preconceito aparece com tanta ênfase, como, por exemplo, o "cabelo ruim" visa em última instância atacar a religião e a cultura, não o cabelo em si.

Isto porque sabemos que formas de penteados podem expressar símbolos de pertença, inclusive para representar o eledá, o orixá da pessoa seu reconhecimento comunitário.

$\mathrm{Na}$ tradição, os penteados podem expressar o mesmo que outros símbolos, conotando ser uma referência a Xangô, a Oxum, a Oyá, etc.

No caso das referências a genitália, está se atacando um elemento simbólico dos mais significativos para a continuidade e expansão do grupo.

Símbolos fálicos da masculinidade referentes à Ogum, ou de interação sexual ao Exu, que incentivavam a expansão das famílias e linhagens, são atacados pelas fantasias recalcadoras e deformadoras da ideologia dos estereótipos do apartheid, especialmente, as religiões ascéticas puritanas, conversionistas e missionárias.

Todas essas referências, porém, não conseguem arrefecer a continuidade da civilização africano-brasileira, que possui na sua pulsão comunal e na sua força imaginal o potencial capaz de chegar até nós e prosseguir do modo como disse D. Mariinha, Iyá Egbé, "nós vamos e os Egunguns, (os ancestrais masculinos) continuarão fazendo o xirê, a liturgia da felicidade". 


\section{Religião, civilização e identidade}

As estratégias do genocídio da política de branqueamento, através do apartheid ideológico dos estereótipos, investindo em relação aos africanos e seus descendentes, a partir das tentativas de inculcação do complexo de inferioridade, só poderia ter eficácia atacando a religião.

Isto porque a religião numa comunalidade sagrada, onde esse mundo e o além são intensamente espaços e tempos interativos, é fonte de identidade e de alteridade.

Ela é fonte de linguagens que emergem como a cultura que alimenta as identidades e faz com que se possa perceber o "outro".

Atacando a religião, se procura, pois deixar os africanos e seus descendentes sem cultura própria sem identidade própria.

Seus valores e linguagens substituídos, tornando-se sua identidade, caracterizadamente, alguém já falou, como "almas no exílio", o livro de Eldridge Cleaver.

Os pontos mais atacados que visam uma estratégia de parar um sistema religioso começam pela deformação da manifestação de orixá ou transe.

Preferimos aqui indagar: como um momento determinado de passagem simbólica, ponto nodal e culminância do contato entre o profano e o sagrado, pode ser comparado a crise de histeria como representou deformadamente Nina Rodrigues?

Como um momento estético de mobilização e forte expressão comunitária, de realização dramática de cosmogonia, ordem simbólica, pode se comparar ao descontrole psíquico da consciência tomada pelo imaginário delirante?

Como a caracterização simbólica do orixá manifestado, com sua expressão contida na liturgia compartilhada num aqui e agora pela comunalidade africano-brasileira, pode reduzir-se as teorias de "papel com tinta" do preconceito do mundo acadêmico acoplado aos interesses da política de branqueamento e industrialização?

Poderíamos ir além referindo-nos ao sacerdócio, à devoção e à preparação do processo iniciático de iawô a egbomi, mas vários autores já se referiram a esses processos que constituem laços de irmandade e comunalidade altamente organizada e hierarquizada.

Outro ponto atacado é a religião em si e seu discurso característico de sua visão de mundo e realização litúrgica, ou seja, as narrativas míticas.

Já nos referimos a laicização do estado industrial burocrático revestido das ideologias positivistas, especialmente, a teoria dos três estágios de Auguste Comte, que tem hoje uma estátua na entrada de Paris V a Sorbonne, principal universidade francesa.

Essa teoria procura desqualificar o mito, como capaz de veracidade, e acusar a religião como fator de ignorância em oposição ao conhecimento 
científico, esse sim, representado como absolutamente verdadeiro, matemático, formalista e, essencialmente, europocêntrico, cercado pela ideologia do poder da escrita.

Sabemos, hoje em dia, a precariedade do discurso científico, suas crises, seus erros e suas formas de recuos e avanços, mas o principal, é que vemos que os valores positivistas absolutamente estão alimentando a técnica e levando a humanidade para sua destruição e a destruição do planeta, assentados nos valores acumulativos e de ganância da sociedade industrial, mercantilista, imperialista, através da poluição da destruição dos sistemas ecológicos, das carências da grande maioria dos povos, das guerras incessantes, da capacidade bélica destrutiva das "grandes potências".

Mas voltemos aos mitos, eles constituem na linguagem que expressa a sabedoria acumulada por muitas gerações de diferentes povos. Eles fazem parte do caminhar da humanidade por espaços infindos e temporalidades imensuráveis. Eles são resultado das elaborações do homo sapiens em volta da fogueira tentando reduzir nossa angústia existencial. A sabedoria acumulada das religiões dos mais diversos povos, ainda mais, os mais antigos, os do continente africano, são os mais significativos e exuberantes tesouros da humanidade alimentando a pulsão do saber.

Somente a infantilidade do continente europeu poderia desprezar e tentar destruir, talvez pela inveja, flagrante e monumental real conquista da humanidade, o saber milenar das tradições dos continentes africano, asiático e americano.

Mas essas religiões não se expressam através apenas do papel com tinta, da escrita erigida como sinal de poder de Estado, "o texto sagrado”!!!?

São elaborações de experiências vividas e concebidas, onde o corpo e a mente se combinam para expressar saber. Aqui a estética se pronuncia por todos os sentidos. A emoção é fator de elaboração conceitual compartilhada pela liturgia da sociabilidade.

A expressão simbólica dos gestos através da dança e da dramatização realiza os mitos aqui e agora, num determinado contexto e num determinado espaço compartilhado por determinados grupos sociais que se pronunciam na música, no canto, nos poemas, nos diversos aspectos da liturgia estética do sagrado, comunicação participante, interpessoal, intergrupal.

Nesse mundo sagrado, da culinária e das oferendas do contato estreito entre esse mundo e o além, é grande a realização do religare, da inter-relação com o mistério e o inefável, o imponderável.

Esse grau de não saber, de "obra aberta", que acompanha o mistério, caracteriza a estética do sagrado e, portanto, da narrativa do mito. O mito é alegórico, insinuante, tenta açambarcar, e representar mundos visíveis e invisíveis, concretos e individualizados, sobrenaturais genéricos. 
Se o positivismo procura realcalcar através da ciência uma dimensão do ser, isto é, o não saber, ou seja, o inexorável mistério do existir, o mito procura exatamente lidar com essa realidade, isto é, a irrealidade.

\section{Exu e "sincretismo"}

Mais um ponto estratégico da ideologia do apartheid da discriminação, é o das deformações dirigidas as representações do orixá Exu.

No panteão nagô, Exu é o orixá patrono do movimento, da ação, da comunicação. Sem Exu, o sistema se paralisa. Ele recebe axé, força sagrada, através das primeiras oferendas para mobilizar o sistema através dos ritos de Ipadê, e sempre é invocado quando se faz oferendas, para que exerça sua função de orixá, de mensageiro, dinamizando e promovendo a interação entre os orixás, ou os ancestrais, e os seres humanos.

Exu é também princípio de vida concreta no aiyê. Na sua qualidade de Bara, oba+ara, o rei do corpo, ele é responsável pela ação e circulação das substâncias característica dos seres. Ele é responsável pelos caminhos, pelas vias de circulação e pela energia promotora de movimento.

Ligado às ações de sucção, a boca, Exu promove as relações do nascituro com a mãe, desde a placenta e do feto, desde o caminhar do espermatozóide em direção ao óvulo. Enfim, sem Exu, não haveria o processo do existir.

Para além das críticas à religião tradicional, pelo positivismo, alguns "cientistas sociais", inconscientemente, mal intencionados, criaram a categoria de "sincretismo", para moldar determinada forma de discriminação.

Essa categoria emerge no bojo da ideologia da "democracia racial" e da "mestiçagem". É o contexto histórico que ocorre em meio à ascensão das ideologias racistas e nazistas.

Em oposição a essas ideologias, eles promovem uma renovação de formas mais sutis de discriminação.

A ideologia da mestiçagem propõe, também, o fim da população negra. Erige como ideal de eu de cidadania brasileira o "mestiço", ou melhor, o moreno.

O vetor da "mestiçagem" continua o mesmo da política de branqueamento, "mestiçar" em direção ao branco.

No plano genético, ainda caminhamos em pleno preconceito, o termo "mestiço" é caracterizadamente usado para os animais, representa o resultado do cruzamento entre eqüinos que culmina na mula, de onde deriva a palavra mulato.

Esse vetor se qualifica na constituição da "meta-raça", isto é, o físico do negro adaptado aos trópicos, ou melhor, a força de trabalho a ser explorada nos trópicos, e a "cabeça" do branco com sua civilização européia. Daí o ideal ideológico da constituição da "Europa tropical", e "Veneza brasileira", etc. 
No que se refere à expressão cultural e a identidade "o fenômeno do sincretismo" seria o resultado do processo dessa sociedade "cordialmente" genocida.

É nesse contexto ideológico do sincretismo, do amálgama entre tradições religiosas, negro-africanas e o catolicismo que o orixá Exu será deformado e representado como diabo.

Assim o diabo, que representa a estruturação rígida básica do cristianismo, a dicotomia entre céu, paraíso e inferno, completamente exógena à religião negro-africana, tenta entrar nesse contexto, como se Exu o fosse, e com essa moral cristã, deveria ser combatido na tentativa genocida de paralisar o sistema da tradição.

Aqueles que vivem a tradição negro-africana sabem que Exu não tem nada haver com isso, sua mensagem chega até nós na continuidade do processo civilizatório que nossos ancestrais, que com sua imensa sabedoria souberam preservar, esse precioso legado da humanidade.

Uma cantiga da umbanda recupera o sentido da complexidade dialética do ir e vir, do fluxo dos destinos em que Exu é o senhor dos caminhos.

\author{
Exu que tem duas cabeças \\ Oh ele olha \\ Sua banda com fé \\ Oh uma é satanás do inferno \\ A outra é de Jesus de Nazaré
}

Mesmo lidando com conceituações católicas, a Umbanda as transforma em adequação ao pensamento teológico da tradição africana.

\title{
Do "trabalhador livre" ao sujeito produtor e consumidor
}

O capitalismo industrial, com sua burocracia e sua gerência a chefaria, teve por finalidade organizar a produção sob os valores de obter o máximo de produtividade com a qualidade determinada no menor tempo possível.

Assim é que são feitos os maiores esforços "científicos e tecnológicos", para alcançar determinados objetivos sempre no sentido de criar mercado, mercados produtivos e consumidores, enfim, alternativos e sempre acumulativos.

Para tanto, há que se criar formas de obtenção da sujeição voluntária, para que o "trabalhador livre" se insira de "boa vontade" no processo produtivo industrial.

É preciso que ele viva as utopias oferecidas pela ideologia do conforto e da cultura do espetáculo visual proporcionada pelos meios de comunicação de massa. 
Para resumirmos o que estamos falando, reportamo-nos aos símbolos máximos do imperialismo britânico, de um lado, o Big Ben, o relógio que procura esquadrinhar a temporalidade do mundo e de outro, o observatório e o meridiano de Greenwich que procura esquadrinhar o espaço do mundo. Entre eles metaforicamente transita o Rolls Royce.

O automóvel condensa os valores de identidade do conforto da sociedade industrial imperial e sua simbologia. No Brasil, esta simbologia está expressa no pacto caracterizado pelos presidentes republicanos, quando no ato de sua posse, cumprem um trajeto protocolar num Rolls Royce.

Após a queda do muro de Berlim, a sociedade industrial imperial se equalizou, as suas ideologias simbolizam o mesmo tom de busca de excelência do aumento das forças produtivas.

Neste contexto, a categoria de "raça" é quem tem agora a função de recalque das diferenças e das diversidades civilizatórias.

A "democracia racial" é desvelada pelos movimentos sociais que brandindo dados estatísticos exigem reparações e compensações dentro de uma política compensatória já traçada pelo próprio sistema, isto é, atender os que sobraram na formação do exército de reserva de mão-de-obra, para que não pratiquem atos de revolta que concorram para a anomia. Tudo se resume então na "discriminação racial" e sua superação através da "inclusão".

Inclusão aí significa adentrar-se nas delimitações do sujeito produtor e consumidor e suas formas de comunicação e identificação; mesmo que isto represente apenas "sonhos a se realizar" pelo mundo encantado da utopia das ideologias do conforto.

A mobilidade das "classes" e das "raças" na sociedade afluente, desde que mantidos os valores das instituições que garantem a expansão da acumulação incessante do capital financeiro mercantil e industrial, torna-se possível. Enfim, pode-se realizar o sonho encantado do operário pobre que chega a presidente, tudo no circuito do capital.

A luta pela "igualdade das raças" nada significa, posto que as "raças" já são iguais, ou melhor, nem existem, há não ser no imaginário ideológico.

Mas existe sim, a diferença entre povos, a diversidade de valores, de cultura, de civilizações, ou como já se referiu Muniz Sodré, as formas e conteúdos da vinculação humana.

É aí, por outro lado, reside à força do recalque da discriminação, resistindo para não aceitar a alteridade.

\section{Ojá e marketing. Filhos de ghandi e ford}

Nas sociedades africanas tradicionais, o oja, mercado em yorubá, é um espaço importante de pulsão da comunalidade. Nele ocorre a circulação das informações da cidade. Além de um centro de troca de mercadorias, ele é importante local de efetiva sociabilidade. 
No âmbito ocidental, mercado é essencialmente econômico, contábil, na verdade, ele é toda a sociedade.Toda ela está voltada para a acumulação do capital. Aqui as relações humanas são esmaecidas, por fórmulas cada vez mais, apenas contábeis, de aproximação.

O imperialismo é uma incessante busca de "mercadogizar" as sociedades, de enlarguecer a sua linguagem mercadológica, seus valores e suas instituições.

No caso presente do contexto atual, se agudiza essa presença que se expressa no mundo encantado da modernidade, na Bahia, representado pela "vinda da Ford".

Em contraposição à toda simbologia que a Ford representa como apanágio da industrialização e do imperialismo, nós temos o símbolo de Ghandi.

Retomando a Bahia como referência simbólica de resistência do imperialismo britânico pelos trabalhadores da estiva, foi fundando o afoxé Filhos de Ghandi.

Saindo pelas ruas durante o carnaval, ele reafirma valores da tradição africana na fricção com os "trios elétricos" dos merchandises, e como já diziam os versos de uma cantiga do afoxé Pai burokô:

"Jiribum bum,

Que terra é nossa..."

\section{Dialética nagô e diversidade humana}

Uma das características mais nítidas da criação do existir é a diversidade dos seres. Somente a produção em série da industrialização tentou camuflar a diversidade, caminhando em direção à tentativa de produção do igual e estabeleceu essa meta como valor à atual fantasia dos clones...

Já na tradição africana, a diversidade é celebrada e os mitos procuram a todo momento tentar estabelecer uma possível coexistência entre diferenças e conflitos.

No conto A Chuva de Poderes ${ }^{3}$, narrado por Mestre Didi, Orunmilá, orixá que representa a sabedoria, é aconselhado por Agemó, o camaleão, símbolo da adaptabilidade, a distribuir os mais diferentes poderes que até então somente ele detinha, para todos os demais orixás. Assim, cada qual passou a ter determinada força e característica, representando princípios diversos e as nuances dos seres constituintes do cosmo.

Outro mito conta que quando as Mães Ancestrais, Iya-Mi Agbá, vieram ao mundo, vieram na forma de sete pássaros, Iyami Eleiyê. Três pousaram na árvore do bem, três pousaram na árvore do mal. E uma voa de uma para outra árvore.

Ela, através de seus poderes, ensejará as benesses daqueles que as respeitarem e amarem e proporcionará os infortúnios aos que as desrespeitarem e desafiarem. 
Respeitar é, sobretudo gratificar as Iyá, dando continuidade à liturgia, proporcionando a circulação do axé, através das oferendas e rituais pertinentes, enfim, preservando e expandindo a tradição.

Mas o que também nos ensina este mito é a concepção dialética do movimento conforme a filosofia nagô.

Enquanto na tradição do Ocidente, os pólos conflitivos e contrários ensejam o movimento que promove a aniquilação deles, como a forma dialética hegeliana, tese $\mathrm{x}$ antítese $=$ síntese, ou na reformulação da divulgação marxista, burguesia $\mathrm{x}$ proletariado $=$ sociedade sem classes, etc. $\mathrm{Na}$ tradição nagô, é diferente, os pólos da dialética se mantém. O movimento é proporcionado pelo ir e vir do terceiro elemento entre os contrários.

A mesma concepção de dialética está presente na forma triangular que se refere ao casal mais descendente, em figurações geométricas variadas, eles simbolizam a expansão de famílias, de linhagens, corrente de existência tão característica da estética nagô e negro-africana em geral.

No ocidente, portanto, dentro de sua delimitação imperial, o outro é sempre impróprio, isto é, projeção da paranóia da conquista.

A organização social está caracterizada, então, pelo Estado uno, totalizante e, no mais das vezes, totalitário.

Todavia, esta situação está gerando uma grande crise que está pondo em risco a própria humanidade.

Várias ações no sentido de garantir o direito a existência de todos os povos estão se processando, de modo que possamos sonhar com novos horizontes assentados nos valores de uma ética futura de coexistência.

A trajetória e as afirmações que emergem das comunidades terreiros tradicionais apontam para a viabilidade desta proposta. É possível coexistir, transitar pelas culturas e relações sociais sem perder sua identidade.

Mãe Aninha Iyalorixá Oba Biyi, nas primeiras décadas do século passado, indicou um caminho: "de anel no dedo e aos pés de Xangô". Essa indicação caracterizou o projeto piloto Mini Comunidade Oba Biyi, realizado pela SECNEB no Ilê Axé Opô Afonjá.Também foi a Iyalorixá Senhora, Oxum Muiwá, Iyá Nassô quem indicou a dinâmica envolvente: "da porteira para fora dentro, da porteira para dentro".

Nesse contexto, Juana Elbein dos Santos, Elefundê Égide Olukotun, elaborou a metodologia desde dentro para desde fora e desde fora para desde dentro, que ensejaram uma das mais significativas renovações no âmbito da antropologia com a concretização do livro Os Nagô e a Morte.

\section{Na tradição nagô a vida e a morte são pólos da mesma dinâmica}

A conceituação de que a vida já inclui a morte faz com que a elaboração da alteridade na tradição nagô seja algo preeminente. 
A morte é o outro ou o outro em sua dimensão mais significativa, posto que ninguém que morreu voltou para contar como é o além.

Por outro lado, é um outro que está em cada ser em sua dinâmica existencial, no caminhar cotidiano do destino.

$\mathrm{Na}$ tradição nagô dentre os ritos que envolvem a morte, na religião, o axexé, significa princípio dos princípios que se renovam.

A comunidade reunida, compartilhando sentimentos e paixões, elaborando o processo do existir, cada qual na sua vez dançando em torno da cuia, ao som da música percussiva e das cantigas pertinentes até o momento da despedida com a saída do carrego, enfim são aspectos de uma comunicação, onde o emocional lúcido caracteriza a vinculação estética e a sociabilidade.

Foi também Juana Elbein dos Santos, que no livro Emocional Lúcido, indicou que esta forma de vinculação humana seria capaz de promover o elo de semelhança e dessemelhança, que permitiria relações, objetivando a busca para a superação dos conflitos violentos que caracterizam a conjuntura mundial.

\section{Dimensões da estética do sagrado}

A dimensão estética que caracteriza as diversas formas de comunicação, ou melhor, de vinculação humana, que tem seu ponto alto na função de tornar magnífico o sagrado caracterizam substancialmente a tradição africana.

Enquanto, na cultura européia, a comunicação mediatizada pelo instrumento técnico de comunicação predomina, realçando a relação olhocérebro, e o livro sagrado é a pedra angular da construção religiosa, na tradição africana o repertório estético-simbólico se expressa em inúmeras formas de comunicação participativa, direta pessoal ou intergrupal.

A música e a dança constituem fatores fundamentais da estética do sagrado.

Através da música de base percussiva, o corpo em movimento se transforma em formas gestuais de representação simbólica na dança.

Mas a eficácia estética não são formas gestuais de comunicação entre os integrantes de um universo simbólico tão somente, mas, sobretudo porque são capazes de propiciar a interação com forças e entidades transcendentes, à relação e a expressão aqui e agora entre o aiyê e o orun; esse mundo e o além.

Quando o então presidente da ONU, Kofi Anan convidou o então Ministro da Cultura do Brasil Gilberto Gil para participar dos "ritos" de despedida das vítimas do atentado ao prédio da administração no Iraque, a dimensão de vinculação estética da humanidade negro-africana emergiu no cenário burocrático.

A improvisação musical entre Gil e Anan contagiou a todos proporcionando a realização do emocional lúcido, na medida em que a 
mensagem era da possibilidade de negociação pacífica dos conflitos, graças à dimensão estética da humanidade.

Entre o povo Ashante, um dos valores mais altos da realeza é a dança.Tradicionalmente, o rei deve ter o dom de dançar, ser um magnífico dançarino, pois a dança é um dos meios mais significativos para a interação entre esse mundo e o além.

Na nossa tradição, tanto no culto dos orixás, ou inkice, ou voduns, a dança, a música e a poesia são elementos fundamentais de vinculação da comunalidade sagrada.

Também no culto aos ancestrais, a cultura religiosa possui essas mesmas características.

Na tradição nagô, um oriki, poema às mães ancestrais, possui uma estrofe que caracteriza o momento de solene alegria da liturgia ao som do toque ijexá no sekere, a cabaça:

Se se kurudu

Aya agba la njo

Nossa grande mãe está dançando...

\footnotetext{
${ }^{1}$ TEJO, Orlando. Zé Limeira, Poeta do Absurdo. João Pessoa: União Editora, 1978. p. 175 e 181.

${ }^{2}$ Cf. LIMA,Vivaldo da Costa. A Família de Santo nos Candomblés Jeje-Nagô da Bahia: um estudo de relações intergrupais. Dissertação (Mestrado) - UFBA, 1977.

${ }^{3}$ Cf. SANTOS, Deóscoredes M. A Chuva de Poderes. Salvador, 1980. Mimeografado.
} 


\section{SÓCIO-PSICANÁLISE DE UM HERÓI DA MODERNIDADE Tarzan, o Homem-macaco*}

Ei-nos escrevendo sobre Tarzan dos Macacos - este personagem da "cultura de massa" que inspirou 26 romances de 90 milhões de exemplares, 42 filmes de cinema, 57 filmes de televisão, 500 emissões de rádio e mais de 12.000 imagens em quadrinhos.

Mais uma vez, um esforço e um desafio de análise para a Teoria das Ideologias. Em número anterior da Revista Vozes - "Ideologia e Psicanálise" procuramos ratificar a posição já adotada em outras vezes quanto à necessidade de aproximação da ciência da história com a psicanálise para o desenvolvimento e aprofundamento dos estudos do nível ideológico. O presente estudo de Tarzan se presta a ilustrar essa necessidade.

É claro que o estudo de Tarzan como um ídolo da "cultura de massa", implica numa ordem de aspectos variados que não trataremos no presente trabalho. Tais aspectos se referem, em primeiro lugar, ao estudo do funcionamento dos Aparelhos Ideológicos do Estado da informação ou da comunicação, em abstrato e em concreto, isto é, a demonstração teórica do conceito de AIE da comunicação e a análise de seu funcionamento, numa conjuntura historicamente determinada; em segundo lugar, este estudo implica em sua inserção na luta ideológica de classe que se desdobraria desde a análise da situação e posição de classe do autor, até as características de ideologia dominante presentes nas suas narrativas; e, sem dúvida, em relação à formação social americana; um aspecto principal: o lugar ideológico marcado das relações conflituosas entre os brancos e os negros, expressas em Tarzan.

No presente trabalho apenas nos referimos, de passagem, a estes aspectos. Vamos nos deter principalmente no estudo do "mito" de Tarzan. Trata-se da primeira estória de Tarzan, narrada por Burroughs, e que marca a

* Artigo publicado, em 1973, na revista de Cultura Vozes. 
personalidade e o caráter do herói. Também caracteriza aspectos da personalidade do autor na medida de suas projeçôes ${ }^{I}$ e de seus leitores na medida de suas identificações ${ }^{2}$.

É esta primeira estória que caracteriza ao mesmo tempo a grandeza e a miséria do herói, a grandeza e a miséria do autor, a grandeza e a miséria dos leitores, que se dividem num mecanismo psíquico de enveredar-se pelos labirintos de defesa onipotente do imaginário ou enfrentar as situações não só do prazer, mas aquelas dolorosas e depressivas que caracterizam a realidade do animal humano, o nascimento, a regra (proibição do incesto), ou a Lei da Cultura e a morte, e que permite a presentificação destas ausências através da fala ou linguagem, isto é, o acesso ao simbólico .

São essas situações universais e enigmáticas representadas no mito ou na obra de arte que permitem que essas narrativas possam, com suas representações, provocar interesse e identificações em diferentes formações sociais historicamente determinadas, como, por exemplo: Édipo. Na Introdução à Crítica da Economia Política, de 1857, Marx assim se refere:

... a dificuldade não é compreender que a arte grega e a epopéia estão ligadas a certas formas do desenvolvimento social. A dificuldade reside no fato de que nos provocam ainda um prazer estético e que eles ainda têm para nós, sob certos aspectos, o valor de normas e de modelos inacessíveis.

São essas normas, Lei da Cultura para Althusser, Regra para Lévi-Strauss ou Ordem para Lacan, que impõem a todos os candidatos, involuntários e forçados à humanidade, a estrutura do invariante Édipo.

São esses modelos, esses ídolos míticos, que promovem a construção do ego através do eu-ideal e do ideal-de-eu e do super-ego.

Esse ego que dentro de suas variaçóes concretas marca a história humana de cada indivíduo.

Essas normas e esses modelos inacessíveis, porque inconscientes, que marcam a individualidade de cada agente social, quer nas suas formas mais "aberrantes" como nas suas formas mais "normais".

Enfim, é a Lei da estrutura invariante presente nessas narrativas que a nosso ver presentifica-as.

Lei invariante de uma estrutura que se organiza a partir da contradição ausência-presença.

É para nós sintomático que Marx indique a revelação do segredo do conhecimento das narrativas mitológicas e artísticas se referindo sempre à infância, à loucura e à naturalidade. Com essas palavras, encerra-se a Introdução: 
Um homem não pode tornar-se criança, sob pena de cair na puerilidade. Mas talvez não teria ele prazer na ingenuidade da criança e tendo alcançado um nível superior, não poderia ele próprio aspirar reproduzir sua verdade? Na natureza infantil, cada época não quer reviver sua própria característica na sua verdade natural? Por que a criança histórica da humanidade, lá onde ela alcançou o seu mais belo esplendor, por que este estado de desenvolvimento sempre redesejado não exerceria um charme eterno? Existem crianças malcriadas e crianças que imitam os adultos. Numerosos povos da antiguidade pertencem a essa categoria. Os gregos eram crianças normais. O charme que exerce sobre nós sua arte não está em contradição com o caráter primitivo da sociedade onde cresceu... (Introdução, p. 175).

Neste ponto, tanto Freud (Totem e Tabu) quanto Marx poderão se enganar, aproximando os fantasmas originários imaginários do inconsciente.

Como se fossem situações sociais históricas originárias e reais. Mas ambos, por outro lado, percebem uma certa interação dialética entre o inconsciente e as formações sociais concretas análogas aos acontecimentos onde as narrativas míticas aparecem:

Para o primeiro, a horda primitiva não seria um fantasma imaginário mas uma situação histórica real. E para o segundo, as revivescências que atualmente temos, trazidas através de identificações com situações vividas por um herói mítico ou trágico, não se referiria aos nossos fantasmas originários inconscientes, mas aos aspectos primitivos da constituição das sociedades ocidentais. Como veremos na análise do mito de Tarzan, as verdades reproduzidas de que Marx fala são para nós uma reprodução do complexo Edipiano, isto é, o núcleo do inconsciente como linguagem. Todavia, o inconsciente nas suas variantes sofre uma sobre-determinação da conjuntura histórica de tal modo que o significado de seus significantes, suas representações são caracterizadas pela luta de classes. É nesse sentido que André Green observou que o poder político, no caso de Édipo, à realeza está ligado à atribuição de prerrogativas sexuais. Nas tradições ocidentais;

... Manifestamente o poder é aqui o fato comum à realeza e à sexualidade. É por isso que um rei envelhecido não é respeitado e sim desprezado, como se tivesse voltado à infância: aquele que é castrado e não mais aquele que castra.

É nesse ponto que a psicanálise deve se aproximar do materialismo histórico, abandonando qualquer tentativa de uma metafísica do desejo e se situando no plano teórico em que a sociedade não se compõe de indivíduos na medida em que o "homem" é o conjunto das relações sociais de produção. 
Assim, Édipo não é somente o mito do incesto e do parricídio, mas também da luta pelo poder e pelo saber. Da mesma forma que Tarzan, como veremos, não é apenas o mito da criança abandonada na selva às voltas com seus enigmas, suas fantasias do parricídio e do incesto; é também o da luta pelo saber que instaura seu poder real sobre a "selva africana".

\section{O "Mito" de Tarzan*}

Em outubro de 1912 foi publicado Tarzan of the Apes por All Story, periódico americano. Sua publicação causou grande repercussão e foram inúmeras as cartas recebidas pelo editor Metcalf e pelo autor, Edgard Rice Burroughs. O teor dessas cartas eram no sentido de que fosse dada continuidade àquela estória em que o herói acabava sendo injustiçado. Elas elogiavam bastante o livro, mas lamentavam seu final. A ida do herói para a "civilização" e suas frustrações com Jane. As identificações dos leitores com o herói foram tantas que, decorrido um ano de sua publicação, estes reclamavam novas obras redimindo o herói de sua depressão, por conseguinte daqueles que com ele haviam se identificado.

No entanto, Burroughs não estava interessado em Tarzan, mas sim no seu herói Jonh Carter de Marte. Somente a pressão dos leitores e do editor é que possibilitou novas publicações que permitiram ao herói, pouco a pouco, se transformar num super-herói.

A tendência do herói em se transformar num super-herói deve-se às características da "cultura de massa" de abrir para os leitores possibilidades de identificações com heróis imaginários, isto é, aqueles que se situam ao nível da onipotência narcísica e servem de ideal de eu aos seus leitores. Assim, Tarzan irá, pouco a pouco, adquirir as feições dos super-heróis (ascetismo, imortalidade, homem de ação, "mens sana in corpore sano", etc.) acompanhada dos aspectos da luta de classe ideológica, colocando-se como todo super-herói, no campo de classe da burguesia; defendendo as relações de produção capitalista e o Estado burguês.

A primeira estória, Tarzan dos Macacos, todavia narra a experiência dramática do animal humano se destinguindo da natureza e tendo acesso à cultura. O acesso à cultura que se dá a partir da proibição do incesto, da ausência e da presença do outro que permite se identificar como outro diante

\footnotetext{
* O Tarzan, no Brasil, em quadrinhos, é publicado em revista pela Editora Brasil-América Ltda. (EBAL), que lança aventuras desenhadas por Russ Manning e Joe Kubert, contando inclusive com uma revista em cores, tiras e páginas semanais pelo jornal O Globo, com estórias desenhadas por Russ Manning (N. da R.).
} 
do Outro e desta forma se situar no simbólico, isto é, nas representações de situações reais e não mais imaginárias.

Enfim, a estória do mito originário que conta a passagem da existência biológica - "natural" à existência humana. A passagem do animal para a Lei da Cultura. Os dois momentos que caracterizam: o momento da relação dual pré-edipiana, relação com a mãe, com a qual se identifica e começa a se perceber como um outro em relação ao Outro (mãe) através de suas ausências e presenças, e o momento da relação triádica do complexo de Édipo, onde o pai se torna no imaginário "infantil” o responsável pelas ausências da mãe e impõe a Lei, a proibição do incesto, que Lacan denomina de Ordem simbólica.

É claro que o "simbólico” sempre será sobredeterminado historicamente, é aí que a inserção na cultura é inserção numa cultura historicamente determinada, isto é, a ideologia de classe nas sociedades divididas pela luta de classe. Todos esses aspectos, primeiras ilustrações de representados no mito de como veremos agora (através das primeiras ilustrações de Hal Foster, em 1929), estarão representados no mito de Tarzan, o homem-macaco:

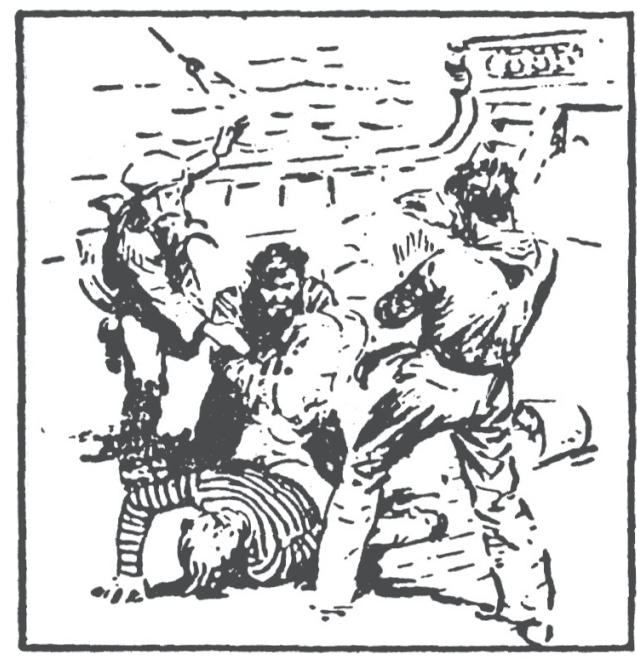

Figura 1

1. O PAI DE TARZAN VIAJA NUM NAVIO para a África a fim de averiguar denúncias de escravismo, quando é surpreendido pela cena do capitão batendo com seu chicote num marinheiro. Outro marinheiro acode o 
companheiro, o capitão puxa seu revólver e vai matá-lo quando é interceptado pelo pai de Tarzan, Lord Greystoke.

"Lord Greystoke bateu no braço do capitão salvando assim a vida de Black Michael. E foi assim que se forjou o primeiro anel de uma cadeia surpreendente de circunstâncias que iria reservar àquele que deveria nascer, uma vida sem igual na história do homem".

Seguiu-se um motim a bordo. Primeiramente os marinheiros invadiram os aposentos de Lord Greystoke levando sua arma (revólver) e deixando um bilhete com ameaças de morte no caso de denunciá-los. É então forçado à cumplicidade. Com grande violência os marinheiros combatem os seus comandantes, o capitão morre com uma machadada que abre sua cabeça até o queixo. Os amotinados tomam o poder do navio.

Lord Greystoke se mantinha bastante apreensivo e temendo pela segurança de sua mulher "e da do esperado pequeno Greystoke, abandonado nas mãos desses semi-bugres ignorantes". "Eis aqui mais dois para os peixes", grunhiu um dos rapazes da tripulação, enquanto brandia um machado. "Black Michael foi mais rápido que o bruto que tinha atacado Lord e Lady Greystoke com um machado, o marinheiro caiu com uma bala nas costas". "Sou eu agora o capitão deste navio, e tudo que disser será executado". "Estes são meus amigos. Não toquem neles".

Para evitar futuras complicações, Black Michael resolveu desembarcar os Greystoke na costa africana. Apesar dos protestos, foram abandonados: "Que surpresas desagradáveis os esperava nesta sombria e misteriosa floresta tropical?"

\section{Comentários:}

Enquanto Pai, Lord Greystoke é possuído por impulsos filicidas. Desejo de matar o filho em função de situações Edipianas não resolvidas. O capitão do navio que agride o marinheiro é uma sua identificação projetiva. ${ }^{9}$ Todavia prefere preservar o filho. No caso, salvando o marinheiro. Esta situação, como é colocada, significa ter então que matar o Pai (o pai encarado como filicida, portanto, o filho como parricida). Identifica-se então com os filhos (marinheiros) que matam o pai (o capitão do navio), mas não escapa da situação fratricida da horda primitiva.

É abandonado com seus fantasmas na selva como castigo capaz de aplacar sua culpa e reparar a morte do Pai.

A marcação ideológica de classe que caracteriza a narrativa está no modo como Burroughs define sua posição de classe na relação do Lord e os 
marinheiros - e esses últimos são considerados "semi-bugres ignorantes". Também "bugres" se aplica como representação da sexualidade que os impulsiona à luta pela mulher; no caso, a representação ideológica da sexualidade é projetada nas classes "inferiores".

2. UMA VEZ NA SELVA, O CASAL SE VÊ às voltas com uma situação inusitada e ameaçadora. Inúmeros perigos os cercam. Principalmente as grandes feras. Eles constroem um abrigo no alto de uma árvore. Mas sempre são atormentados por aparições sinistras.

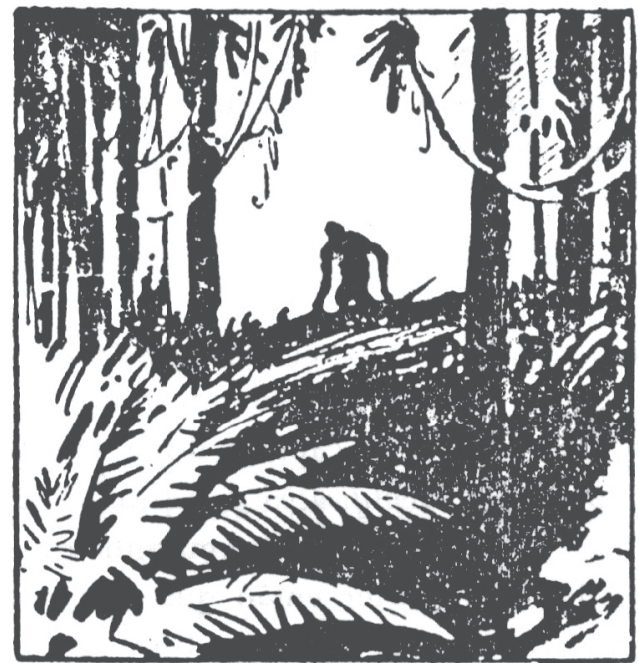

Figura 2

"Na relativa segurança de seu abrigo aéreo, Lady Greystoke se agarrou de repente ao braço de seu marido. 'Olhe' - murmurou - '0 que é aquilo? Um homem?' Distinguia-se vagamente uma grande silhueta que por entre as sombras se mantinha erecta, como atenta aos barulhos e depois se voltou lentamente para o fundo entre as árvores da floresta". Aos poucos eles conseguiram construir uma cabana com um razoável conforto, e apenas a presença dos animais selvagens os preocupava. Por três vezes viram grandes silhuetas, mas nunca puderam saber se de homens ou de feras. 
Num dia em que Greystoke se afastou da cabana, um gigantesco antropóide se aproximou, atacando-o. Estando apenas com um machado, tentou correr para a cabana enquanto Alice, sua mulher, que nunca manejara armas, com a "bravura de uma leoa que protege seus filhotes" disparou um dos fuzis de seu marido e o macaco, que apesar de atingido por Greystoke estava prestes a matá-lo, voltou-se sobre ela e caiu morto.

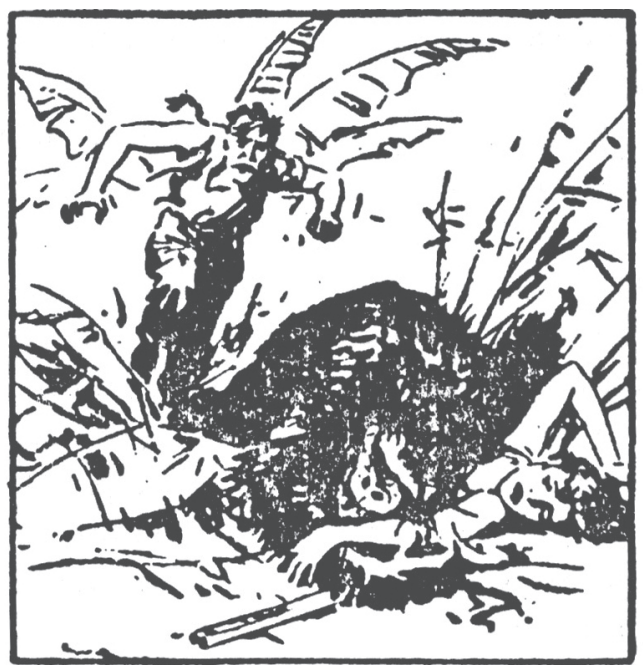

Figura 3

Após o acidente, Alice foi levada para o interior da cabana desacordada. Recuperando os sentidos, maravilhada, com um ar satisfeito, disse: "oh, Jonh, é tão maravilhoso estar verdadeiramente em nossa casa. Eu tive um terrível pesadelo, querido".

Após acariciar sua fronte, ele respondeu: "tente ainda dormir e não se preocupe".

Nesta mesma noite, enquanto um leão rugia e um leopardo gritava, uma criança nascia na pequena cabana vizinha da selva primitiva. Lady Greystoke não se recuperou nunca mais do choque que lhe causou o ataque do grande macaco. Ela nunca mais saiu da cabana.

Greystoke cada vez foi sendo mais assediado pelos grandes macacos, mas os espantava com seus fuzis.

Um ano depois do nascimento de seu filho, Alice morreu de morte natural. A Greystoke restou a terrível situação de que lhe incumbia a extrema responsabilidade de tomar conta de seu tão pequeno filho. 


\section{Comentários:}

1. Greystoke se sente ameaçado por seus fantasmas (ver fantasmas originários, nota 7). Sentindo-se culpado pela morte do Capitão do navio (Pai primordial - ver nota 10), vive a sexualidade com enorme sentimento de culpa. Desta forma, a sexualidade é representada como algo primitivo - macaco - e destrutivo. Neste caso, seria uma projeção da cena originária - onde, segundo Freud, a criança observa a relação sexual entre os pais e com certos índices fantasmagóricos interpreta esta relação como um ato de violência da parte do Pai. Uma vez o pai identificado, incorporado a si (ver nota 10), ele vivencia a sua sexualidade da mesma forma.

2. Por seu lado, Alice vivencia a sexualidade também como algo primitivo e fantasmagórico - macaco. A saída da cabana com a arma pode significar a saída do útero, ou se despregar da mãe para ganhar o falo do pai - representado pelo fuzil de Greystoke.

"Ela havia sempre tido medo das armas de fogo, e jamais as tocou. Agora, ela se precipita sobre o macaco com a "bravura de uma leoa protegendo seus filhotes".

Todavia, Alice vive também a cena originária imaginando a sexualidade como primitiva e mortal. E somente a coragem de defender a possibilidade de vir a ter filho (leoa que protege os filhotes) é que neutraliza sua repressão e a impulsiona para a relação sexual.

Seu destino é motivado pela possibilidade de ter um falo - isto é, na forma de filho. Ela não assume a castração e imagina ter um falo na forma de filho. Também seu marido ("filhote de leoa") será imaginado como filho, isto é, seu falo. Ela não possui o falo, mas imagina ter. Controlará seu marido impondo a lei - castração - aceita também por esse - morte do macaco que representa a sexualidade. Ele será um falo para ela e não terá um falo. Situação de Filho.

Para Alice a experiência da sexualidade será traumatizante - voltará para a cabana, de onde não sairá nunca mais. Negou sua participação na relação sexual vivenciada como um pesadelo.

Sua morte sem razões fisiológicas explícita - "seu fim foi calmo" caracteriza a relação de correspondência entre o princípio de Nirvana e a pulsão de morte, isto é, o fim das tensões do aparelho psíquico, levá-lo a zero ou reduzi-lo o mais possível. Também o retorno à cabana - ao útero - pronunciava esta tendência.

O que pode ter imediatamente levado Alice a esta situação foram as freqüentes situações parricidas, fratricidas e filicidas que, como objeto desejado, causou entre o Pai primordial e os irmãos. Agora, com o nascimento de seu filho, essa situação se renovaria. Com o fim da situação dual - mãe/filho - e o início da relação triádica, a entrada no complexo de Édipo, a partir de um ano de idade, ela se veria novamente ante a situação passada, quando 
Greystoke matou (ou causou a morte do Capitão do navio) e quase foi morto (pelos marinheiros) por causa dela. Agora seria entre Greystoke (no lugar do Pai) e seu filho.

3. Por seu lado Greystoke continuou afugentando as investidas dos macacos - seus impulsos inconscientes. Sublimava através de leituras e do diário que escrevia - diário que irá mais tarde, no decorrer da estória, revelar todo o enigma, o mistério de Tarzan.

A morte de sua mulher pode ter sido vivenciada como causada pelo nascituro:

"A última anotação de seu jornal foi inscrita no dia seguinte da morte de sua mulher onde relatava os tristes detalhes de uma maneira tão prosaica que acrescentava ao aspecto patético, doloroso e sem esperança deste golpe cruel: 'Meu pequeno filho chora para ser alimentado - Ó, Alice, Alice que devo fazer?' A esta pergunta, somente uma resposta: o exemplo da própria mulher. Greystoke deixou-se abater pelos macacos sem que dessa vez disparasse um só tiro, como veremos adiante".

Para o pequeno abandonado, a herança fantástica de ter sido o "culpado da morte dos pais"...

A dificuldade da situação para Greystoke seria a projeção sobre o filho de sua própria vivência quando filho, isto é, de ter sido o culpado da morte do Pai. A matar o filho ou ser morto por este, ele preferiu morrer nas mãos dos macacos e assim encerrar esta tensão ambivalente.

3. “... DURANTE ALGUM TEMPO, NENHUM grito veio romper a calma de morte na floresta, cessado os gemidos apiedados do pequeno filho de homem esfomeado. Depois, vieram os macacos".

"O velho Kerchack, o rei dos macacos, estava com uma grande raiva entre seus congêneres. Os mais novos e os mais leves membros da tribo subiam para os galhos mais altos, arriscando sua vida para escapar a esta cólera incontrolável.

Outros machos se salvavam correndo para todas as direções, mas não tão cedo a ponto de Kerchack ter tempo de matar um deles esmagando-lhe entre seus possantes maxilares cheios de baba. Uma jovem fêmea desafortunada abandonou sua presa incerta. Um grito selvagem e ele estava sobre ela, batendo nela cruelmente com um pau até que seu crânio rachou.

Depois ele percebeu Kala, com seu bebê. Ainda possuído por seu estado de raiva, Kerchack se aproximou dela. Ela tentou fugir saltando de um galho para outro. "0 choque súbito fez com que soltasse seu bebê"... "Ela deixou aquela pequena coisa cair, dando reviravoltas até se espatifar no solo dez metros abaixo". 
"Com um surdo gemido desesperado, Kala se precipitou para seu bebê ignorando o perigo. Quando reuniu as partes do pequeno corpo mutilado, e o apertou contra seu peito, a vida o havia abandonado. Kerchack não ousou atacá-la. Sua raiva demoníaca se apagou tão rapidamente quanto havia começado".

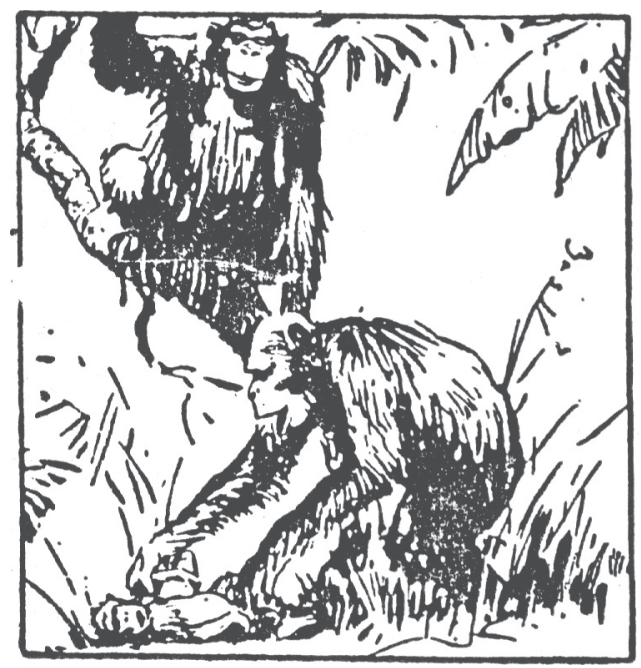

Figura 4

Uma vez cessada sua raiva, Kerchack dirigiu a tribo para o mar. Ele havia decidido visitar o interior desta cabana misteriosa. E queria a qualquer preço possuir o pequeno bastão negro que havia feito chegar sua terrível mensagem de morte para tantos membros da tribo. Durante todo o caminho, Kala levou seu bebê morto, apertando-o forte contra seu peito.

Chegando sutilmente sem barulho à cabana, Kerchack observou que não havia nenhum traço de homem à sua volta. Aproximou-se da entrada e vislumbrou Greystoke. Apenas um gemido de choro se elevou do pequeno berço. Kerchack entrou. Greystoke se levantou, as armas estavam longe, presas à parede. Havia muitos macacos. Quantos ele jamais saberia.

Enquanto o rei dos macacos descia o corpo flácido de quem já havia sido Lord Greystoke, ele se virou para o berço. Mas já Kala lá estava adiantando-se a ele, e antes que pudesse interceptá-la, ela se amparou da criança deixando cair seu bebê morto no berço e escapou pela porta, subindo para o alto de uma árvore apertando contra si a criança que gritava. A fome os fez se aproximar rapidamente. Durante este tempo, as feras na cabana examinavam seu conteúdo com prudência. Uma vez seguro de sua morte, 
Kerchack não molestou mais o corpo de Lord ou de Lady Greystoke. Então, ele parou diante do fuzil pendurado na parede. Finalmente, ele o pegou e o examinou de perto.

Os outros macacos estavam sentados, dispostos em torno de seu chefe. Súbito, o dedo de Kerchack se apoiou sobre o detonador. Houve um barulho ensurdecedor! Os macacos caíram uns sobre os outros na sua precipitação por se evadir.

Transcorreu um ano desde que Kala havia tomado o pequeno bebê, e ele não andava sozinho. Ele não podia subir nem caçar só, como os pequenos macacos de sua tribo. Tublat, o companheiro de Kala, estava muito ciumento e queria eliminar a criança.

Tublat discutiu com Kala até que ela ficou encolerizada e não quis mais escutá-lo. Mas Tublat encontrou Kerchack e pediu para, com sua autoridade, eliminá-lo. Todavia Kala ameaçou de abandonar a tribo. Assim Tarzan - o pele branca - pôde sobreviver. Com dez anos de idade, levou um companheiro para beber água e viu seu rosto refletido. "Ele enrubesceu de vergonha, comparando seu rosto e seu corpo nu com o de seu irmão mais favorito".

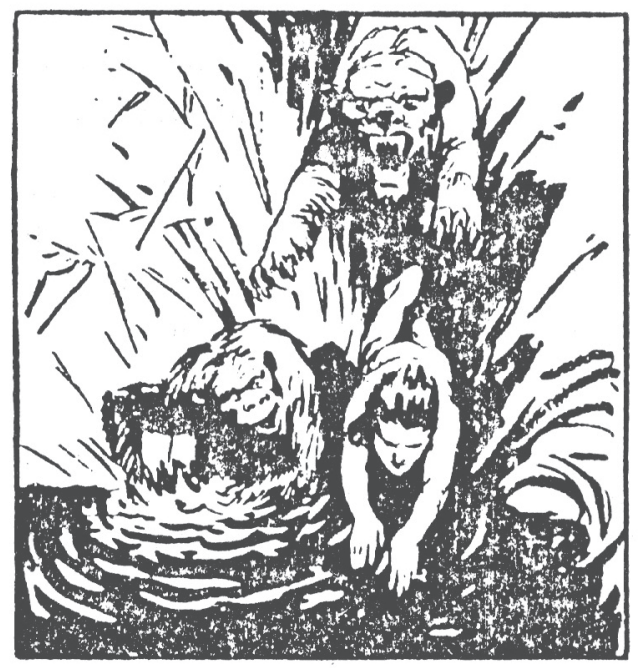

Figura 4a

Estavam absorvidos no exame de suas fisionomias quando Sabor, a leoa, se aproximou. Ela avançou com precaução. Depois, rugindo, lançou o bote. Tarzan escapou pulando na água, mas o seu irmão, paralisado pelo medo, morreu em suas garras. 


\section{Comentários:}

1. Kerchack é o Pai castrador desta horda de Macacos. Os jovens machos padecem em suas mãos; deseja todas as macacas para si, e a sexualidade é vivenciada como algo destrutivo - (ver nota sobre cena originária). Quando a macaca divide a ternura com um filho, sente-se ameaçado e mata.

"Sua raiva demoníaca se apagou tão rapidamente quanto havia iniciado" (Fig. 4).

2. Ele não pode admitir a rivalidade do Pai de Tarzan e parte para matá-lo e ficar com seu falo - bastão negro - fuzil. Mas se sente perseguido por usá-lo e foge assustado.

Vê então no filho do branco, salvo por Kala, uma ameaça de vingança e compartilha do desejo de Tublat de matá-lo. Este, tem ciúmes pois Tarzan toma todo o tempo da companheira. Uma vez que deixariam de possuir o objeto (Kala), desistiram da ação.

3. Todavia para Tarzan subsistir, deverá aceitar a castração imposta. Isto é, aceitar a proibição de possuir a mãe, ser filho. Sua parte macaco processo primário - é morta pela leoa - no caso mãe fálica, castradora. Tarzan aceita se sujeitar à castração regredindo ao útero - água (como defesa).

Esta situação pode ser vista também sob outro aspecto - inicialmente a criança se identifica com o corpo da mãe. Esta identidade se caracteriza como uma forma de defesa diante da situação angustiante da criança de não poder controlar nem ter uma idéia do próprio corpo - Estágio do espelho. Para Lacan, esta identificação não permite que ela possa se identificar como outro diante do Outro. Só há para ela um outro imaginário do qual é parte. Ela idealiza na mãe um corpo unitário e com uma auto-suficiência onipotente. E aí, se identificando também se imagina onipotente.

A passagem desta situação imaginária para uma situação no simbólico, onde a criança deve-se assumir um outro; este reconhecimento se dá através da lei - em que a mãe reprime e proíbe em nome do Pai.

A mãe repressora é representada pela leoa. A parte macaco com que Tarzan se identifica com a mãe, e que é “morta” por esta separação, não é elaborada por Tarzan, que regride a uma situação uterina. Procurando permanecer no imaginário, não deixando desenvolver-se o "trabalho de luto". ${ }^{\text {. }}$

4. PARA TARZAN, A CABANA FECHADA e silenciosa era sempre uma fonte de mistério e de prazer sem fim.

Kala the havia explicado que seu pai fora um estranho macaco branco e ele ignorava que ela não fosse sua mãe.

“Tarzan entrou suavemente e com precaução; viu três esqueletos; sem prestar muita atenção, abriu as malas, examinando minuciosamente as armas, 
estranhos objetos, livros e roupas. Encontrando um punhal de caça bem afiado, se cortou imediatamente no dedo. Um alfabeto de criança ilustrado the interessou enormemente. A noite caía”.

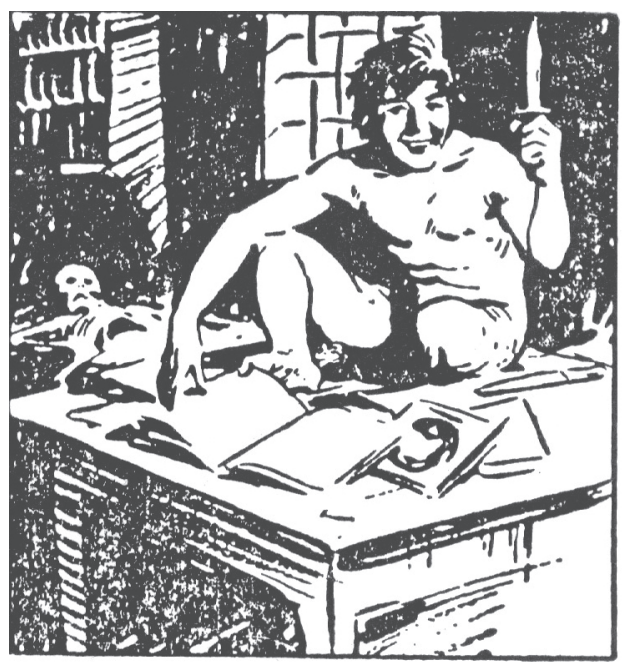

Figura 5

“Tarzan partiu, levando o punhal de caça para mostrar aos seus amigos. De repente, uma enorme silhueta se destacou. Era Bolgani, o monstruoso gorila. Tarzan sabia que deveria permanecer e combater por sua vida. Ele quebrou o elan da fera. Rolaram sobre o solo no frenesi furioso do combate.

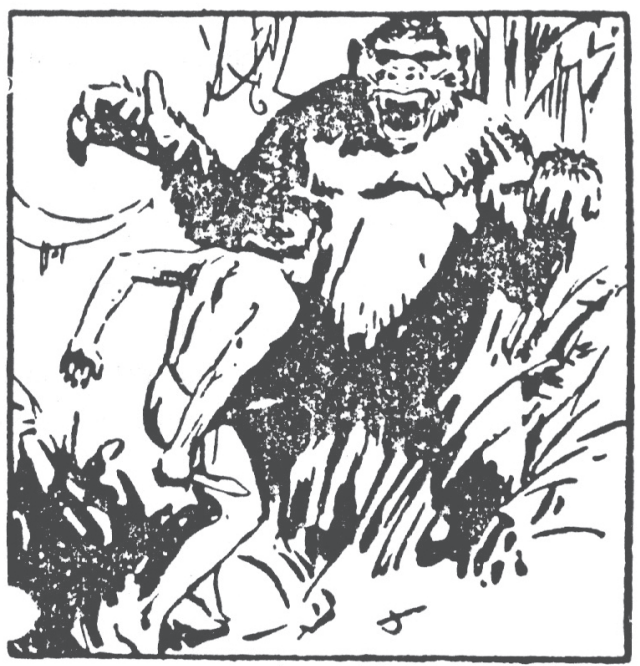

Figura 6 
Ocasionalmente a lâmina penetrou no gorila, depois Tarzan repetiu os golpes até que o enorme macaco tombou languidamente e, ao seu lado, Tarzan".

A tribo dos macacos tinha ouvido o grito desafiador do gorila. Kala sentiu a falta de Tarzan, porém Kerchack, o rei dos macacos, se opôs a que se enviasse ajuda. Ele não gostava deste estranho pequeno órfão.

Mas Kala precipitou-se em sua procura e ainda o encontrou com vida. Levou-o desacordado para uma árvore e durante algum tempo Tarzan foi tratado por ela, até que passado um mês ele estava mais forte e mais ativo do que nunca.

\section{Comentários:}

1. Tarzan começa a iniciar as tentativas de entrada no simbólico cujo significante fálus é básico, então começa a se ver às voltas com situações em que ele está sempre representado.

Procurando entre os objetos de seus pais (curiosidade sexual), entra no útero (cabana) - e lá encontra o pênis (faca). É uma característica da fantasia dos pais combinados, da mãe fálica detentora do falo do pai (é na cabana que descobre a faca) (ver nota 15).

2. Mas a posse deste objeto, é causa de uma situação persecutória e de disputa. Essa disputa demonstra uma nova tentativa de Tarzan de ter acesso ao simbólico. Entretanto, ele mata suas partes mais sexualizadas (macaco) partes do pai (fantasia de sexualidade deformada) já introjetada em si e, após, recusa esta situação caindo em sono e retornando à mãe sem a "faca".

O acesso ao simbólico, o fim do complexo de Édipo, só se dá através da renúncia da mãe como mulher proibida e o poder de ter a sexualidade liberada para as demais mulheres. Mas para isso deverá admitir a potência do pai como igual, e não procurar destruí-lo para ficar com a mãe. Quando o falo não será mais representado como arma destrutiva - (faca) - mas como algo capaz de criatividade e prazer.

5. TARZAN ENCONTROU A FACA AO LADO dos ossos do gorila. Entrando na cabana sua atenção se fixou nos livros ilustrados. Através de sua razão, descobriu que ele era de uma outra raça diferente de seus companheiros. Ele era HOMEM. Ele não sabia ainda, não podia falar a linguagem dos homens.

Comentários:

1. Tarzan atravessa um período de busca de identidade. A sexualidade é sublimada pelo saber. No entanto, este saber é uma forma de incorporação das potencialidades a ser utilizado em futuras atuações.

2. Reconhecendo-se como outro, e começando a elaborar pela situação - presença-ausência - da mãe na situação dual e depois o impedimento do incesto na relação triádica, uma identidade própria, é então que se tem acesso à linguagem. Para Lacan, é a ausência que é preenchida pela palavra - (Da!) e (Fort!) na linguagem de Freud (ver nota 3). 
6. OS MACACOS REALIZAVAM UMA FESTIVIDADE onde comiam um inimigo. Tarzan entrou na dança fúnebre, depois foi a repartição. Tarzan com sua faca logo cortou um bom pedaço. Por isso foi perseguido por Tublat que não pôde alcançá-lo. Tarzan se refugiou no alto de uma árvore. E observou Tublat descarregar sua raiva em Kala, sua mãe adotiva. Tarzan saltou em direção ao bruto enraivecido com sua faca afiada, e depois de lhe dar diversos golpes e de seu inimigo ter rolado pelo solo, "ele jogou a cabeça para trás e imitou o feroz grito de desafio dos macacos".

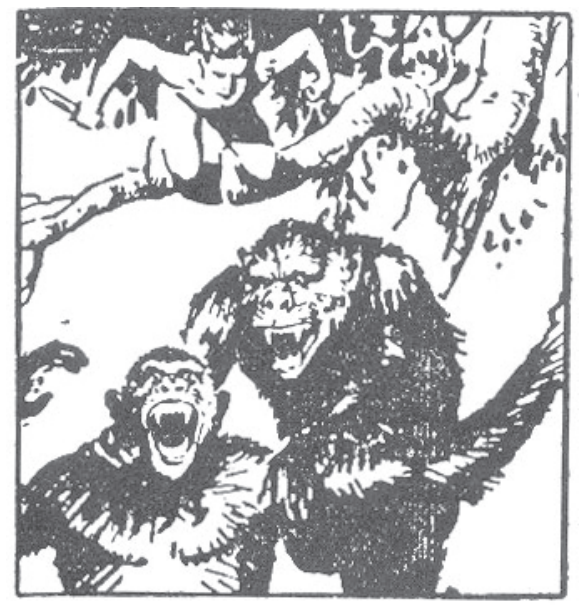

Figura 7

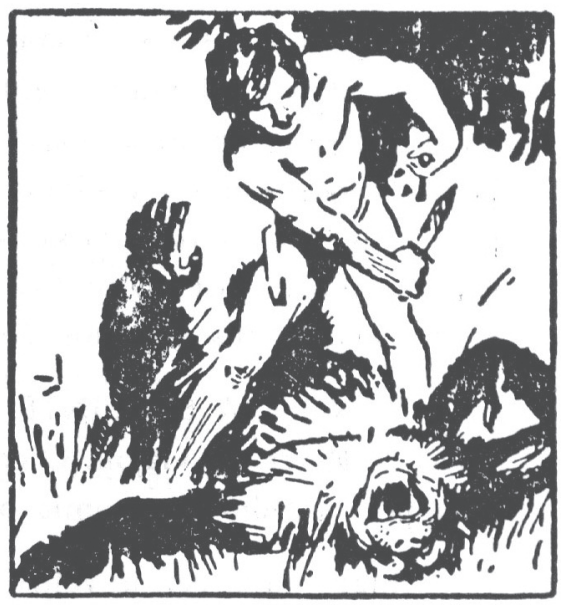

Figura 8

\section{Comentários:}

1. Mais uma vez o tema do festim canibalístico da horda primitiva (ver nota 10). Tarzan comete o parricídio dando um grito de triunfo. Este grito que caracterizará o aspecto maníaco que envolve sempre situações que se repetirão, uma forma de se defender do trabalho de luto. Também a visão que Tarzan tem do ataque de Tublat a Kala caracteriza a cena originária.

2. A situação do festim canibalístico se refere ao estado sádico-oral, caracterizado pela aparição dos dentes e da atividade de morder. A incorporação toma o sentido de uma destruição do objeto, o que implica na entrada em jogo da ambivalência na relação com o objeto - "o desejo libidinal de sugar se acompanha do objetivo destrutivo de aspirar, esvaziar e esgotar - sugando".

Daí para comer ou receber para Tarzan, possa significar também situações de morte e perseguição. Sente-se perseguido por Tublat. E repetem-se situações. Trata-se da Compulsão de repetição. ${ }^{1}$

Diante da cena originária, forma de percepção da relação sexual dos pais como sendo uma forma de agressão paterna. A sexualidade é então vivenciada, não como algo criador, terno e amoroso; mas como algo destruidor 
e mortífero. Pois, ela também foi proibida a si como algo de ruim. Esta parte do pai como sexualidade destrutiva, é sempre representada por aspectos macacos de Tarzan, isto é, representação dos aspectos do processo primário.

7. NO DIA SEGUINTE, APÓS A MORTE DE Tublat, o povo de Kerchack viajou. O corpo de Tublat foi deixado onde caiu pois a tribo não comia os próprios mortos.

Mais uma vez, a velha Sabor cruzou o caminho deste povo. Enquanto os macacos subiam para o alto da árvore, Tarzan se instalou embaixo e jogou um ananás na cabeça de seu antigo inimigo.

"Um plano ambicioso the veio à mente. Ele havia matado o feroz Tublat; agora ia se lançar no encalço de Sabor, a astuciosa, e abatê-la da mesma forma".

Ao mesmo tempo, o pequeno inglês aspirava a esconder sua nudez. Aprendera nos seus livros que todos os homens usavam roupas. Enquanto os macacos e demais animais andavam nus. Assim, ele desejou a pele de Sabor, a leoa.

Neste dia, houve um terrível dilúvio. Os membros da tribo tremiam de medo. A tempestade durou horas. Para Tarzan, foi a revelação da utilidade das vestimentas.

"Como ficaria bem sob o manto espesso de Sabor!"

Ele preparou um laço. Do alto de uma árvore lançou-o sobre o pescoço da leoa, mas com suas possantes garras ela partiu-o e investiu contra Tarzan. Durante horas, ela permaneceu sob a árvore, saltando vez por outra sobre ele. Tarzan debochava dela e dançava. Com um grito, subiu pelas árvores e desapareceu.

Depois reencontrou-se com os seus e narrou os detalhes de sua grande aventura, com um ar de grande conquistador que impressionou os seus inimigos mortais. Kala dançava alegremente, orgulhosa.

Tarzan crescia e se desenvolvia cada vez mais forte e sábio. Tornou-se amigo de Tantor, o elefante, e caminhava pela floresta noite adentro. Todos os outros animais, exceto os de sua tribo, eram seus inimigos.

\section{Comentários:}

1. Depois de ter cometido o parricídio, matando Tublat, Tarzan fica perseguido. Sente-se perseguido pelos fantasmas da castração - no caso, a leoa - a mãe fálica ${ }^{15}$. Para Tarzan, o fálus é sempre um objeto "mau", isto é, capaz de levar à morte, e sempre projetado num outro - como representante do processo primário. Assim, a leoa castra, e o próprio Tarzan vê seu pênis a faca - como herança paterna, e de uso destruidor - castrador. Assim, a sexualidade é vivida por ele como algo desejado de um lado, porém com muita carga de agressividade e destruição. 
Para ter acesso e possibilidade de realização de seu desejo incestuoso, Tarzan planeja matar a leoa como afastou Tublat. Para poder realizar o desejo incestuoso, deverá afastar os aspectos da mãe castradora, a mãe que realiza a Lei, isto é, a proibição do incesto sobredeterminado pela presença do pai.

2. Todos esses desejos parricidas e incestuosos envolvem o posterior sentimento de culpa e necessidade de castigo. ${ }^{16}$ Mas, no caso de Tarzan, esse castigo será projetado no outro mesmo que sofreu a agressão, quando objeto mau, ou em outro agressor substituto quando objeto bom. Queremos dizer que quando Tarzan é castigado, é o outro que lhe fez sofrer uma humilhação e ele vai à desforra, e assim sucessivamente, como veremos adiante. Tarzan não assume, isto é, não percebe, que ele sempre procurará situações penosas triádicas de disputa, agressividade, ódio e morte.

Assim, a tempestade, o dilúvio, a presença do castigo criam a necessidade de buscar no agressor fantasmagórico - a leoa - através de sua morte, a pele, que neutralizará o frio e o medo. Ao mesmo tempo, a incorporação desta pele protetora pode significar uma identificação com o agressor. E Tarzan, de castrado poderá se transformar em castrador.

3. A forma como narra os episódios com a leoa para seus irmãos macacos caracteriza uma maneira de entrada na puberdade onde Tarzan vai formando o seu ego à luz de uma combinação de seu eu ideal (ver nota 5), e seu ideal de eu (ver nota 5). Características narcísicas onipotentes e exibicionistas se combinam com um narcisismo secundário de sua identificação com Tantor, o elefante, o animal mais forte e sábio da selva, com sua imensa tromba.

4. Esta situação da adolescência é característica do início da genitalidade, e possibilidade concreta de realização do desejo incestuoso.

A alegria e o orgulho com que Kala recebe as narrativas do Tarzan adolescente, mostram características de uma boa mãe capaz de na fantasia adolescente caracterizar uma possibilidade de sedução.

8. AOS DEZOITO ANOS, TARZAN JAMAIS tinha visto um ser humano. Mas, um dia, quando tentava compreender o mistério da cabana, a segurança de sua floresta de outrora iria ser comprometida para sempre.

Eram cerca de cinqüenta guerreiros negros armados de lanças de madeira, grandes arcos e flechas envenenadas. Depois chegaram as mulheres e as crianças, seguidas de outros guerreiros. Eles fugiam dos soldados brancos, porque tinham massacrado um oficial. Instalaram-se para construir uma nova aldeia. Tarzan permaneceu pensativo.

Um dia, Kulonga, filho do velho rei, aventurou-se muito longe para o oeste. A cinco quilômetros a oeste, dormia a tribo de Kerchack. Cedinho, os macacos estavam na floresta em busca de alimentos. Tarzan, segundo seu hábito, ia para a cabana. Kala, muito ocupada, deslocava-se lentamente para oeste. De repente, ela se deparou com Kulonga. Kala recuou, mas era tarde. Kulonga a seguia de perto. "Enfim carne! Ele poderia matá-la". 
"A lança afundou em Kala. Mas apenas feriu-a! Soltando um forte grito de dor, a macaca se voltou e se vergou. Os gravetos já estalavam sob os pés de seus semelhantes que acudiram ao grito de Kala. Kulonga preparou uma flecha envenenada e a disparou direto no coração do grande antropóide".

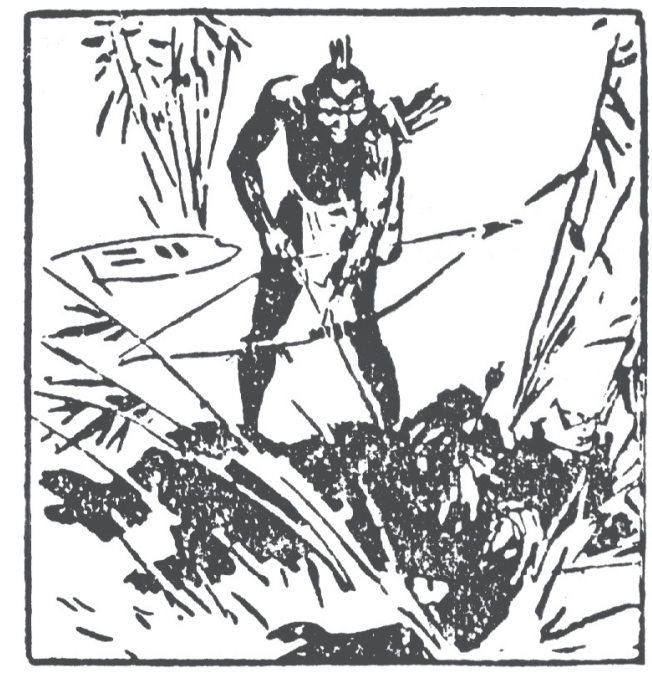

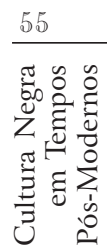

Figura 9

"Com uma terrível raiva, Kala tombou diante dos olhos estupefatos dos membros da tribo. Rugindo e vociferando, os macacos se precipitaram sobre Kulonga, que saiu em disparada".

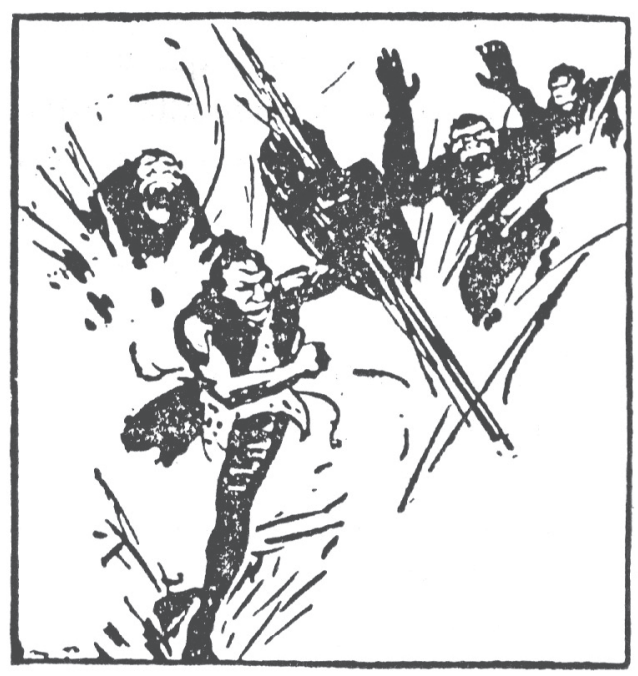

Figura 10 
“Tarzan estava atento; ele sabia que algo não ia bem. Encontrou toda a tribo reunida falando alto perto do cadáver de sua mãe adotiva. Permaneceu num estado de dor e ódio. Ele lançou seu ignóbil grito de desafio, batendo no peito com as mãos, e depois caiu sobre o corpo de Kala e chorou com o coração partido de solidão".

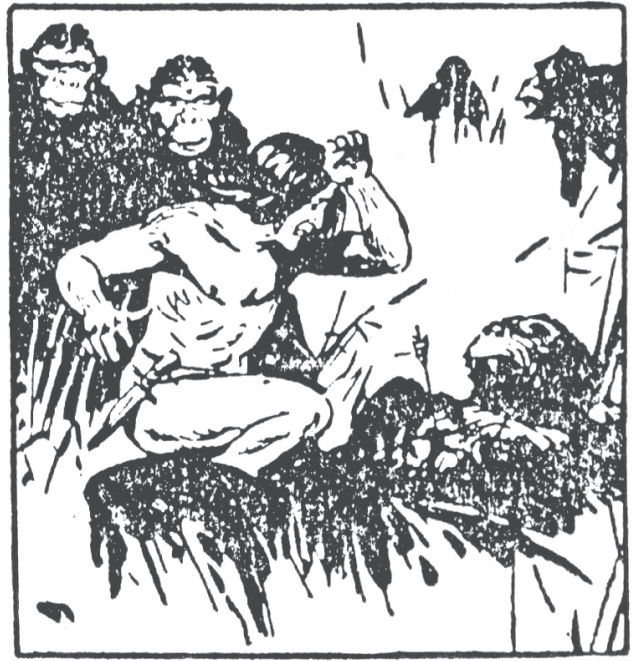

Figura 11

Tarzan saiu em busca de Kulonga: "encontrou as marcas de pés parecidos com os seus, maiores. Seu coração batia forte. Poderia perseguir um Homem? Sua própria raça! Ele vigiava Kulonga. Este caçou um javali. Comeu uns pedaços assados e partiu. Tarzan também comeu os restos deixados do javali, e continuou em sua busca, observando sempre os gestos do homem.

Num momento, Kulonga reparou que suas flechas e seu arco haviam desaparecido do alto de uma árvore. O guerreiro negro entrou em pânico, Ele só possuía um punhal. Resolveu voltar rápido para sua aldeia. Quando Tarzan percebeu sua intenção, decidiu matá-lo".

"Quando Kulonga saía da selva, uma corda fina caiu sobre ele. O nó se fechou em seu pescoço. A seguir, Tarzan puxou a vítima para o alto de seu abrigo nas árvores. Depois descendo até a altura do corpo de Kulonga cravou seu punhal de caça bem no coração. Kala estava vingada! Ele examinou minuciosamente o negro. 
"Tarzan estava esfomeado. Ali havia carne que a ética da selva lhe permitia comer. Seu punhal estava prestes a desmembrar Kulonga. Súbito, uma estranha dúvida o paralisou. Ele jamais hesitara em comer a carne de suas presas, mas tratava-se de um homem! Será que os homens comem os outros homens?"

Tarzan observou o movimento na aldeia. Uma mulher molhava as

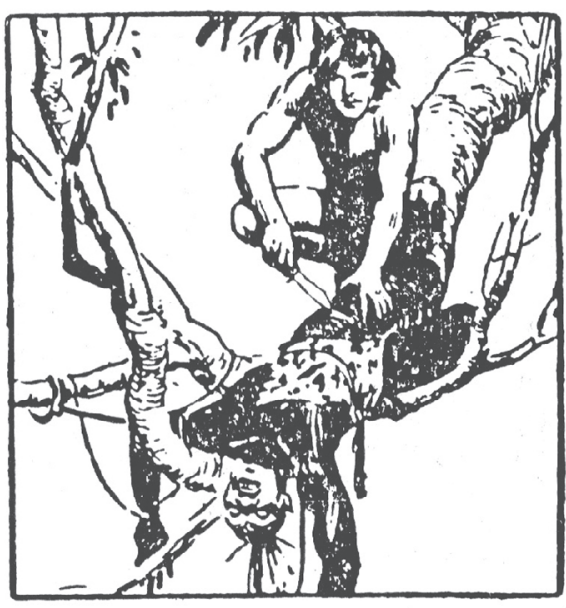

Figura 12

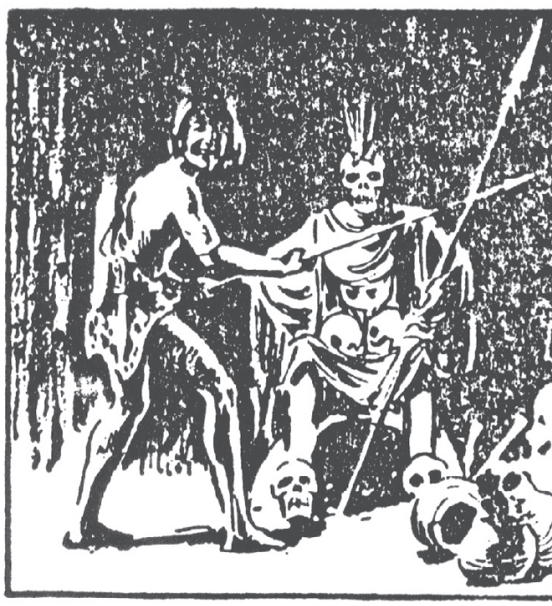

Figura 13

pontas de algumas flechas numa mistura fervente. Ele sabia que essa mistura é que matava. Desejou algumas dessas pontas que causavam a morte.

Um guerreiro negro emitiu um terrível grito quando se deparou com o cadáver de Kulonga pendurado na árvore. A aldeia acorreu imediatamente em efervescência. Tarzan se aproveitou para entrar na aldeia e se apossar de algumas flechas. Ele sabia que haviam encontrado o corpo de sua vítima. Entrando numa cabana, viu várias armas e vários crânios.

"Tarzan reuniu todos esses crânios velhos. Sobre o do alto ele prendeu o cocar de Kulonga, o filho morto do chefe. Depois, ouviu gemidos e longas lamentações fúnebres. Rapidamente, ele desapareceu nas folhagens derramando o caldeirão borbulhante, depois de ter apanhado uma boa quantidade de flechas envenenadas".

"Os indígenas voltavam trazendo o corpo de Kulonga. Encaminharamse justamente para a cabana em que Tarzan estivera. Eles saíram conversando em altos brados selvagens e confusos. Em seus pobres cérebros só imaginaram as mais terríveis explicações superticiosas." 


\section{Comentários:}

1. Tarzan se encontra em condições de exercer a genitalidade. Uma vez cometido o parricídío e afastada as fantasias da castração, ele pode ter acesso à mãe. Seu desejo incestuoso se apresenta em sua identificação projetiva com Kulonga, filho do Rei.

Pois Kulonga, como "negro", pode representar o processo primário. Digo, como negro, porque ele nas sociedades americanas está ideologicamente representado como detentor dos desejos irreprimidos, entre os quais a sexualidade, vista no código "branco" como algo de embrutecido e a ser sublimado ou reprimido violentamente.

Agora, a razão do negro estar representado como portador da sexualidade na ideologia dominante "branca" não é só o fato dele ser "negro", mas de ser representado como proletário ou escravo.

A repressão sexual sempre existiu mais para a "classe dominante" que para a "classe dominada". Isto principalmente por razões econômicas. A filha do senhor não pode se permitir casar com alguém que não acrescente algo à riqueza ou ao status da família. Por isso, deverá guardar-se até o casamento, em geral 'arranjado' pelas famílias aristocráticas entre si.

Já a classe dominada, "livre de tudo", sempre pode ter uma repressão sexual mais atenuada não tendo razões econômicas para reprimir suas filhas, exigir casamentos "escolhidos". Desta forma, ela pode representar externamente e com adequação determinada o processo primário.

Neste caso, a "classe dominada" é combatida não só ao nível das relações políticas e econômicas, mas também da moral, discurso ideológico da repressão sexual, que re-inscreve a "classe dominada" como tendo comportamentos "imorais" - desrepressivos. Este combate é feito principalmente através dos Aparelhos Ideológicos do Estado, sendo que na nossa formação social o AIE da comunicação é um dos mais efetivos.

Deste modo, nada mais característico que o significado dos significantes, que compõem a lógica do inconsciente naquilo que há de pulsões mais primárias, esteja circunscrito neste nível da luta de classe ideológica. Assim, em Tarzan, o "negro" é o significado para o significante genitalidade. No caso, claro, o negro na projeção do branco. Especialmente Burroughs sempre desconheceu totalmente o que fosse o negro, salvo o "negro" representado na ideologia dominante, a que favorece os interesses da "classe dominante". E ele sempre se situou como um "branco" pequeno burguês, atuando no campo de classe da burguesia.

Além disso, a sexualidade que o negro passa a representar não é aquela criativa e terna, mas a sexualidade fantasiada pela repressão do incesto: uma deformação do desejo. Podemos dizer que uma vez não se saindo do complexo de Édipo, não se pode exercer a sexualidade livremente, isto é, sem o estigma da proibição. 
Nas estórias de Tarzan em quadrinhos, sempre veremos o negro ou castrado, submetido à lei de Tarzan, ou "mau", isto é, portador de uma sexualidade "deformada", isto é, deformada à luz da própria projeção de Tarzan (portador do código do branco) e pronto a desafiar e combater o poder do Rei das selvas.

2. O lugar do outro que, na relação triádica, exerce a sexualidade, é visto por Tarzan como algo de mortífero e brutal (ver cena originária, nota 12) e ele sempre será preenchido à luz de um simbólico ao sabor da luta de classes. O outro será negro, árabe, ou alguém branco de uma nacionalidade que no momento apresenta-se na conjuntura internacional como inimigo dos EUA.

3. Na identificação projetiva com Kulonga, Tarzan praticara o incesto com Kala, mas com isso provocaria a morte da mãe (fantasia da cena originária). Tarzan, representado por Kulonga, se sentirá perseguido por seus fantasmas macacos, e resolverá castrar-se matando Kulonga, ou matando uma parte sua.

4. Tarzan matando Kulonga incorpora sua roupa e suas flechas (já havia também comido o javali), mas não elabora o luto dessa morte. Maniacamente, procura reconstruir a vida de Kulonga, juntando os esqueletos e pregando suas coisas no crânio envelhecido.

Para Tarzan, as representações do fálus envolvem situações de destruição - flechas, faca, lanças, etc.

Burroughs apresenta os negros como criaturas crédulas, que só encontram explicações "superticiosas" para os acontecimentos que os envolvem. Farão de Tarzan um de seus deuses.

No caso específico, mais uma vez a estrutura de Totem e Tabu. Perseguidos pelos brancos, por terem-nos devorado, os negros acabarão, na seqüência da narrativa, por repararem sua culpa elegendo Tarzan como o que veio thes castigar e reparando a culpa persecutória erguendo um altar em sua homenagem com presentes para ele.

9. FOI UM TARZAN BASTANTE MODIFICADO que voltou à tribo de Kerchack. Contava suas gloriosas aventuras e lhes mostrava os troféus de sua conquista. Kerchack ficava invejoso com este estranho membro de sua tribo. Procurava um pretexto para descarregar sua raiva sobre Tarzan.

Durante um mês, exercitou-se com arco e flechas. Na cabana encontrou o diário de seu pai, algumas fotos e um medalhão de diamante. Ele colocou em seu pescoço, imitando assim o homem negro que havia visto.

Quando acabou o seu estoque de flechas, ele repetiu a farsa enquanto os indígenas se compraziam num festim canibal. Mais uma vez, eles ficaram apavorados com esta nova manifestação, de um poder diabólico, extra-terrestre e invisível. 
Encontrando Sabor - a leoa -, Tarzan lhe lançou uma flecha. Depois de ter tirado sua pele, ele se apressou em juntar-se à tribo para contar a sua nova e espantosa bravura. Só Kerchack estava por detrás, cheio de raiva e de ódio. De repente algo queimou sua cabeça. Ele saltou no centro da assembléia: "Desça, Tarzan" gritou, "venha lutar".

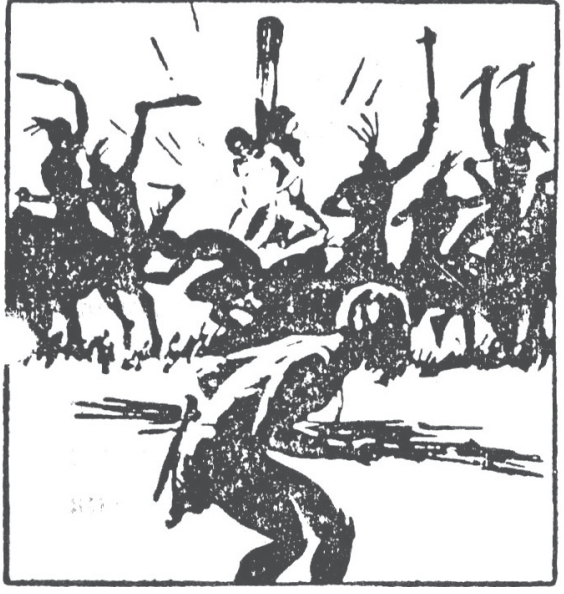

Figura 14

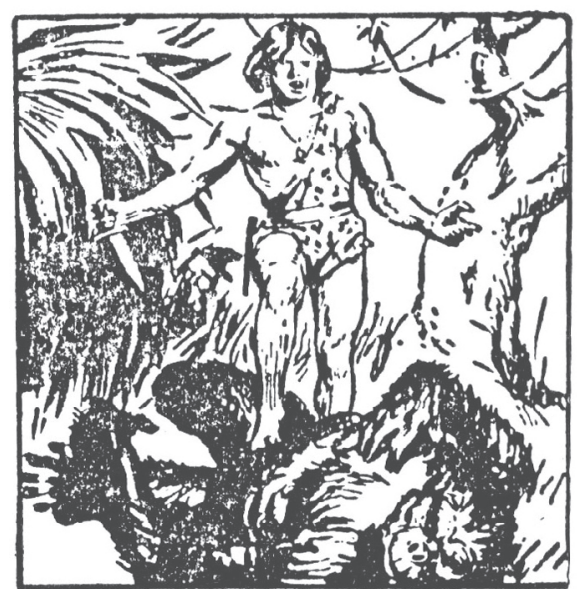

Figura 15

"Com a respiração presa, a tribo olhava Kerchack atacar, rugindo com sua silhueta estúpida. Tarzan pegou seu punhal e enfiou sob o coração de Kerchack! Eles lutaram até o fim; depois, o grande corpo estremeceu, apagouse e despencou flácido. Kerchack estava morto. E foi assim que o jovem Lord Greystoke tornou-se "Rei dos Macacos".

Comentários:

1. Tarzan conseguiu eliminar Sabor, a leoa, que representa a mãe castradora que impõe a lei, a palavra do pai castrador. Esta situação é de verdadeiro desafio para Kerchack, o pai castrador. Resta a ele impor diretamente a lei sobre o filho ameaçador, parricida e incestuoso.

2. Tarzan bem modificado é aquele capaz de possuir o fálus e a genitalidade, porém manejando de forma destrutiva, e com isso se tornando sempre passível de perseguição. Kerchack é um dos seus mais terríveis perseguidores. Somente a sua morte poderia, em sua fantasia, encerrar o ciclo persecutório. Todavia, apesar de vencê-lo e tornar-se o Rei dos macacos, Tarzan continuará se sentindo perseguido pelos que castra e que mata outros macacos, outras leoas e outros negros, homens e feras que o perseguirão. Agora como castrador. ${ }^{17}$ 
3. Tarzan se configura aqui dividido entre um aspecto de sua personalidade, Lord Greystoke, outro, de Macaco. A seqüência da narrativa caracterizará as tentativas de Tarzan de alcançar e descobrir uma personalidade própria, sua identidade. Sem todavia conseguir elaborar o luto de todas as perdas de objetos sofridos, ele permanecerá na ambigüidade e será forçado a renunciar à mão de Jane, no final da história, que caracteriza esse romance familiar. ${ }^{18}$

\section{Notas}

${ }^{1}$ No sentido propriamente psicanalítico deve-se entender por projeção, a operação em que o indivíduo expulsa de si e localiza no outro, pessoa, coisa (ou personagens, no caso de um escritor), qualidades, sentimentos, desejos que desconfie ou recusa em si próprio.

Por identificação, entendemos o processo psíquico pelo qual um sujeito assimila um aspecto, um atributo de outro (no caso, os personagens da narrativa, os heróis) e se transforma totalmente ou parcialmente sobre o modelo deste. A personalidade (aspecto da construção do ego) se constitui e se diferencia por uma série de identificações.

3

3 Para esclarecermos os conceitos de imaginário, simbólico, e Lei da Cultura reproduziremos abaixo um texto de Althuser, de seu artigo "Freud e Lacan", de janeiro de 1964, e publicado pela Ed. Portugália Estruturalismo, Antologia de Textos Teóricos:

“... Está aí, sem dúvida, a parte mais original da obra de Lacan: a sua descoberta. Esta passagem da existência (no puro limite) biológica à existência humana (filho de homem), demonstrou Lacan que era realizada sob a Lei da Ordem, que eu designarei por Lei da Cultura, e que esta Lei da Ordem se confundia na sua essência formal com a ordem da linguagem. Que devemos entender por esta fórmula à primeira vista enigmática? Primeiro, que a totalidade desta passagem apenas se pode apreender nas modalidades de uma linguagem recorrente, apenas designada pela linguagem do adulto ou da criança em situação de cura, designada, marcada, localizada, sob a lei da linguagem na qual se fixa e se dá toda a ordem humana e, portanto, todo o papel humano. Depois que nesta convocação de cura pela linguagem, transparece a presença atual, perpetuada, de absoluta eficácia da ordem na própria passagem, da Lei da Cultura no devir humano.

Para indicar, em algumas breves palavras, anotemos para esse efeito os dois grandes momentos desta passagem: - O momento da relação dual pré-edipiana, em que a criança, tendo apenas que tratar com um alter-ego, a mãe, que esconde a sua vida com a sua presença (da!) e com sua ausência (fort!) (expressões da língua alemã tornadas célebres por Freud) vive esta relação dual no modo do fascínio imaginário do ego, sendo ela própria este outro, tal outro, qualquer outro, todos os outros da identificação narcísica primária, sem nunca poder colocar-se diante do outro ou de si mesmo na distância objetivadora do terceiro.

- O momento do complexo de Édipo, onde uma estrutura triádica surge sobre o fundo da estrutura dual, perturba a sua economia, quebra os seus fascínios e introduz a criança naquilo que Lacan chama a Ordem Simbólica, a da linguagem objetivante que lhe permitirá, portanto, ao pequeno situar-se como criança humana num mundo de terceiros adultos.

Portanto, os dois grandes momentos: 1. o do imaginário (pré-edipiano); 2. o do simbólico (o complexo de Édipo resolvido), ou, para falarmos aqui uma linguagem diferente, o da objetividade reconhecida no seu uso (simbólico), mas ainda não conhecido (surgindo o conhecimento da objetividade numa outra "idade" e também numa outra “prática”).

${ }^{4}$ K. MARX. Contribution à la Critique de L'Économie Politique. Paris, Editions Sociales, p. 175.

Convém aqui mais uma vez observarmos a aproximação de Marx e Freud: Na Interpretação dos Sonhos Freud se refere:

“Se Édipo Rei comove um auditório moderno tanto como comovia o auditório grego contemporâneo à obra, a explicação só pode ser a seguinte: seus efeitos não estão no contraste entre o destino e a vontade humana, mas 
devem ser atribuídos à natureza particular do material sobre o qual esse contraste se apóia. Deve haver aí qualquer coisa que faz ressoar em nós uma voz pronta para reconhecer a força coativa do destino em Édipo... Seu destino nos comove unicamente porque ele bem poderia ter sido o nosso, porque o oráculo faz incidir sobre nós o mesmo anátema que incidiu sobre ele antes de nosso nascimento".

Por eu-ideal entenda-se o ideal de onipotência narcísica forjado sobre o modelo do narcisismo infantil. Este ideal-narcísico de onipotência se caracteriza por uma identificação primária com um outro ser, investido de onipotência, isto é, a mãe, num registro imaginário. O Eu-ideal se revela ainda pelas admirações apaixonadas pelas grandes personagens da história ou da vida contemporânea que caracterizam a sua independência, seu orgulho, sua ascendência. Por Ideal de eu se entenda a instância da personalidade resultante da convergência do narcisismo (idealização do eu) e das identificações aos pais, a seus substitutos e aos ideais coletivos... O ideal de eu constitui um modelo ao qual o sujeito procura se conformar. A origem do ideal de eu é principalmente narcísica: "o que o homem projeta diante de si como seu ideal é o substituto perdido em sua infância, naquele tempo onde ele era seu próprio ideal”. (J. Laplanche e J. B. Pontalis, Vocabulaire de la Psychanalyse). Em sua relação com o super-ego poderíamos dizer que este corresponde à autoridade e o ideal de eu ao modo como o sujeito deve se comportar para responder às exigências da autoridade. Esses conceitos abrem a possibilidade de se demonstrar teoricamente a categoria de "estrutura psíquica de vassalo", elaborada por W. Reich e utilizada por mim em diversas ocasiões, especialmente em O Segredo da Macumba.

6

${ }^{6}$ Por ausência-presença devemos entender o par de oposição que caracteriza a estrutura do inconsciente como linguagem, ou a lógica dos significantes em Lacan.

7 Os fantasmas originários se caracterizam por serem na verdade etruturas fantasmagóricas típicas (vida intrauterina, cena originária, castração, sedução) que a psicanálise encontra como que organizando a vida fantasmática, o mundo das fantasias imaginárias. Quaisquer que sejam as experiências pessoais dos sujeitos, a universalidade desses fantasmas se explicam, segundo Freud, pelo fato de serem transmitidos filogeneticamente. Este caso é assim explicado por Freud:

"É possível que todos os fantasmas que hoje nos são contados na análise ( ... ) tenham sido outrora, nos tempos originários da família humana, realidade, e que acreditando nos fantasmas, a criança preenche somente, com a ajuda da verdade pré-histórica, as lacunas da verdade individual” (J. Laplanche e J. B. Pontalis, Vocabulaire de la Psychanalyse).

É a partir da análise do Homem dos lobos que Freud compreendeu que seus fantasmas originários não tinham relação com acontecimentos reais. Ao contrário, pode-se situar então os fantasmas originários ao mesmo nível que o núcleo da linguagem inconsciente, o complexo de Édipo.

8 André Green, Édipo: Mito ou Verdade, in "Freud - Documentos 1969”, p. 26.

Por identificação projetiva Melanie Klein designa um mecanismo que se traduz por fantasmas, onde o sujeito introduz sua própria pessoa em totalidade ou em parte no interior de um objeto para possuir e controlar. É o que Freud denomina projeção. (Ver nota 1.)

${ }^{10}$ Horda primitiva - Freud propugnou no Totem e Tabu pela existência de uma tribo primordial chefiada por um pai violento e ciumento, que mantinha todas as mulheres guardadas para ele e expulsava da horda os filhos adolescentes. Então, os filhos expulsos, que não viam com bons olhos esta situação, reuniram-se em bando, mataram e comeram o pai. Ao devorarem o pai primordial, cada um dos irmãos realizou seu desejo de identificação.

Com a morte do pai e sua incorporação canibalística, os irmãos tiveram duas atitudes. A primeira é que cada irmão era agora rival dos demais pela posse das mulheres. No caso, a disputa dos marinheiros por Alice, querendo matar Greystoke, com excessão de Black Michael. A segunda, os impulsos de ternura recalcados em relação ao pai se transformam em remorso, necessidade de punição ou masoquismo moral, onde os indivíduos buscam situações penosas e humilhantes, e no caso, o que o pai impedira, eles agora proibiam a si próprios. No texto, Black Michael impede aos irmãos e a si Lady Greystoke, abandonando-a em terra. Por seu lado, Greystoke, também necessitando de punição, será sempre acossado por fantasmas do pai que não permite a si a sexualidade. Esta situação poderia ter facilitado o aparecimento de sentimentos e atividades homossexuais que contribuíram nesta fase para salvar a organização social. 
Por trabalho do luto devemos entender um processo intrapsíquico, consecutivo à perda de um objeto de ligação ou dependência e pelo qual o sujeito consegue progressivamente se desembaraçar. Para Freud, a existência de um trabalho intrapsíquico de luto é atestado pela falta de interesse pelo mundo exterior que se instala com a perda do objeto: toda a energia do sujeito perece absorvida por sua dor e suas lembranças até que o eu, por assim dizer, obrigado a decidir se quer partilhar deste destino (objeto perdido), considerando o conjunto das satisfação narcísicas que lhe restou em vida, ou se se determina a romper seu laço com o objeto enfraquecido.

12

Por cena originária entende-se a cena de relação sexual entre os pais, observada ou suposta a partir de certos sinais e fantasmas infantis. Ela é geralmente interpretada pela criança como um ato de violência por parte do pai.

13

Deve-se entender por compulsão de repetição o processo incoercível e de origem inconsciente, pelo qual o sujeito se coloca ativamente em situações penosas, repetindo assim experiências antigas sem se lembrar do protótipo e, ao contrário, tendo a viva impressão de que se trata de algo que é plenamente motivado na atualidade.

${ }^{14}$

O Processo Primário e o Processo Secundário são dois modos de funcionamento do aparelho psíquico. Em primeiro lugar, podemos dizer que, do ponto de vista tópico, o processo primário caracteriza o sistema inconsciente, e o processo secundário, o sistema pré-consciente.

Do ponto de vista econômico-dinâmico no caso do processo primário, a energia psíquica flui livremente, passando sem entraves de uma representação à outra. Ela tende a reinvestir plenamente as representações ligadas às experiências de satisfação construtivas do desejo (alucinação primitiva). No caso do processo secundário, a energia está primeiramente "presa" antes de fluir de modo controlado; as representações são investidas de um modo mais estável, a satisfação é transferida, permitindo assim experiências mentais que colocam à prova as diferentes vias de satisfação possíveis.

A oposição entre processo primário e processo secundário é correlato daquele do princípio do prazer e princípio da realidade (ver Vocabulaire de la Psycanalyse, J. Laplanche e J. B. Pontalis, PUF).

${ }^{15}$ Por mãe fálica entendemos as fantasias que representam a mulher com o pênis do pai incorporado. Trata-se da teoria dos pais unificados que esclarece a fantasia segundo a qual a mãe incorporaria o pênis do pai no decorrer do coito, assim a mulher que possui um pênis representa os pais acoplados. Esta fantasia decorre de fantasmas muito precoces: cena originária fortemente marcada de sadismo, interiorização do pênis do pai, representação do corpo materno como receptáculo de "bons" e sobretudo "maus" objetos.

16

Entenda-se necessidade de punição a exigência interna que se apresenta na origem do comportamento de certos sujeitos, cuja prática psicanalítica mostra que eles buscam situações penosas ou humilhantes e se comprazem com elas (masoquismo moral).

17

Tarzan não consegue entrar na situação depressiva causada pelo aparecimento do super-ego. A presença do objeto desejado e a ausência do objeto desejado, provoca uma situação de ambiguidade e finitude que só pode ser entendida passando-se por uma fase depressiva, onde os objetos sejam sempre avaliados dentro desta globalidade. Onde a presença não seja entendida como eterna e ela só seja presença pela ausência. Não elaborando as ausências, o próprio Tarzan destrói as presenças desejadas, para não sofrer a depressão. Os objetos são então desvalorizados e destruídos. Mas essa destruição é sublimada por um grito maníaco e a instalação de uma situação proibitiva persecutória, Sente-se perseguido por desejar, realiza seu desejo como se fosse outro, e sente-se perseguido e com necessidade de sofrer um castigo. Mas esse castigo também recai sobre o outro. A esta situação M. Klein classifica de esquizo-paranóide - especificamente seriam os seguintes traços: "As pulsões agressivas coexistem com a pulsões libidinais e são particularmente fortes; o objeto é parcial (principalmente o seio materno) e dividido em dois, o "bom" e o "mau" objeto; os processos psíquicos prevalescentes são a introjeção e a projeção; a angústia intensa é de natureza persecutória (destruição pelo "mau" e "bom” objeto) (J. Laplanche, Pontalis, ob. cit.).

${ }^{18}$ Por romance familiar designa-se os fantasmas pelos quais o sujeito modifica imaginariamente seus laços com seus pais (imaginando, por exemplo, que ele é uma criança encontrada). Tais fantasmas se encontram manifestos nos delírios paranóicos. Na neurose, surge de várias maneiras: a criança imagina que não é nascida de seus pais reais, mas de pais prestigiados, ou de um pai prestigiado, e imagina sua mãe com aventuras secretas, ou ainda que ele é o filho legítimo e seus irmãos e irmãs bastardos.

Suas motivações: desejo de rebaixar os pais sob um aspecto (macaco, no caso) e exaltá-los (Lord) sob outro, desejo de grandeza, tentativa de contornar a barreira contra o incesto, expressão da rivalidade paterna, etc. 



\section{ANOS DA DECLARAÇÃO UNIVERSAL DOS DIREITOS DO HOMEM \\ De que Homem?*}

A emergência da burguesia a partir das cidades Estados, os burgos, suas rotas comerciais pela Europa e, após as "grandes descobertas", o comércio da Companhia das Índias Ocidentais e Orientais, o ouro e a prata saqueados durante o genocídio dos aztecas, maias e incas, o lucrativo tráfico escravista em meio ao genocídio de povos africanos, a emergência desenfreada do capital financeiro, girando em torno do que se considerou chamar período colonial mercantil escravista, viria a enobrecer aventureiros e burgueses, o self made man, e a aburguesar a nobreza e a igreja. Convém salientar a importância de uma intelligentzia separada dos conventos, agora a serviço da ciência, mas sobretudo da técnica, protegida pelos interesses burgueses. Esses são alguns fatores que proporcionaram mais tarde o advento de novas mudanças históricas, sinalizados pela independência dos EUA, pelas revoluções inglesa e francesa, e, sobretudo, pela independência do Haiti. De súdito à cidadão, uma nova etapa da humanidade se constituía; tanto mais quando entra em cena o processo de industrialização e com ele o trabalhador livre, "livre de tudo", como disse Marx, ao sabor do mercado de trabalho e dos aparelhos ideológicos do Estado. Sob o imaginário do liberté, egalité, fraternité, da "teoria política dos três poderes”, os estados nacionais e seus mercados vão se constituindo.

Por outro lado, à tour de force, o processo de independência do Haiti incentivava as mudanças. A tentativa de Toussaint L'Ouverture de negociar a independência com a França de Napoleão, culminou com a prisão e deportação do líder haitiano que morreria nos Jura. Todavia, a intervenção do exército francês comandado por L'Eclerc fracassaria frente à liderança quilombola ou aldeã de Dessalines, e logo ficavam estabelecidos os limites parisienses do Liberté, egalité, fraternité...

\footnotetext{
*Artigo publicado, em 1998, pelo Caderno Cultural do Jornal A Tarde.
} 
A derrota do exército napoleônico na ex-colônia, onde 95\% da população eram de africanos e seus descendentes, fez com que a Europa, principalmente a Inglaterra, mudasse de política econômica. O fim do tráfico escravista, políticas emigratóricas visando o "embranquecimento" das colônias, abolição e mesmo independência e liberdade de mercados - desde que regidos pelo enlaçamento ao capital financeiro - caracterizam uma nova época. No Brasil independente, José Bonifácio assegura ao cônsul inglês, que podem pôr a pique os navios negreiros, pois a independência visa um país para os brancos. Logo se viu que a passagem de escravo a cidadão não ocorreria em águas tranqüilas. A intelligentzia a serviço da hegemonia burguesa logo produziria a ideologia do racismo, que alimentaria a razão de Estado para que esse mantivesse suas características europocêntricas. Nos EUA, após o genocídio dos povos indígenas em meio a "vocação imperialista" da conquista do oeste - visando a saída para o Oceano Pacífico em direção a Ásia -, após a guerra de secessão e a abolição da escravatura, institui-se o apartheid. No Brasil, enquanto Gobinneau, hóspede de D. Pedro II, ensaia suas teorias racistas, o imperador incentiva a imigração européia nas regiões Sul e Sudeste, ocupando a ferro e fogo o território dos chokleng e caigang. A "guerra do Paraguai", incentivada e financiada pela Inglaterra, atende a seus diversos interesses. Destrói a política econômica de autodeterminação do Paraguai e diminui drasticamente a população guarani e seus descendentes, de um lado; de outro, diminui significativamente a população negro-brasileira - maioria entre os soldados convocados para a guerra - e enlaça o governo brasileiro ao capital financeiro do império britânico, financiando equipamentos bélicos, promovendo a indústria armamentista e projetando uma nova expectativa de mercado ao capital industrial. Na República, após a abolição, o racismo adquire novas feições. Ele irá mediar as novas relações sociais de produção que constituem o "trabalhador livre".

Elaborado e proclamado a partir da Universidade, a teoria dos três estágios da humanidade de Auguste Comte irá se complementar com a do "desigual desenvolvimento filogenético da humanidade" - evidentemente com a "raça branca" no topo - de Nina Rodrigues. Conseqüências dessas teorias que alimentam a Razão de Estado republicano, o genocídio de Canudos, a perseguição policial às religiões afro-brasileiras, a política de abandono e a intensificação da imigração européia - são também aspectos de atuação política do novo imaginário ideológico impresso na bandeira, "ordem e progresso".

Na Europa, o racismo é ideologia em alta, alimentando as disputas de mercado entre países coloniais e imperialistas. O clímax acontece com a ascensão de Hitler; genocídio de judeus e conflitos bélicos que ameaçariam a humanidade, tanto mais quando o mundo atônito presenciou as conseqüências da bomba atômica lançada sobre os japoneses pelos EUA. Com o fim da II Guerra Mundial, os vencedores se reuniram para definir a nova geopolítica. 


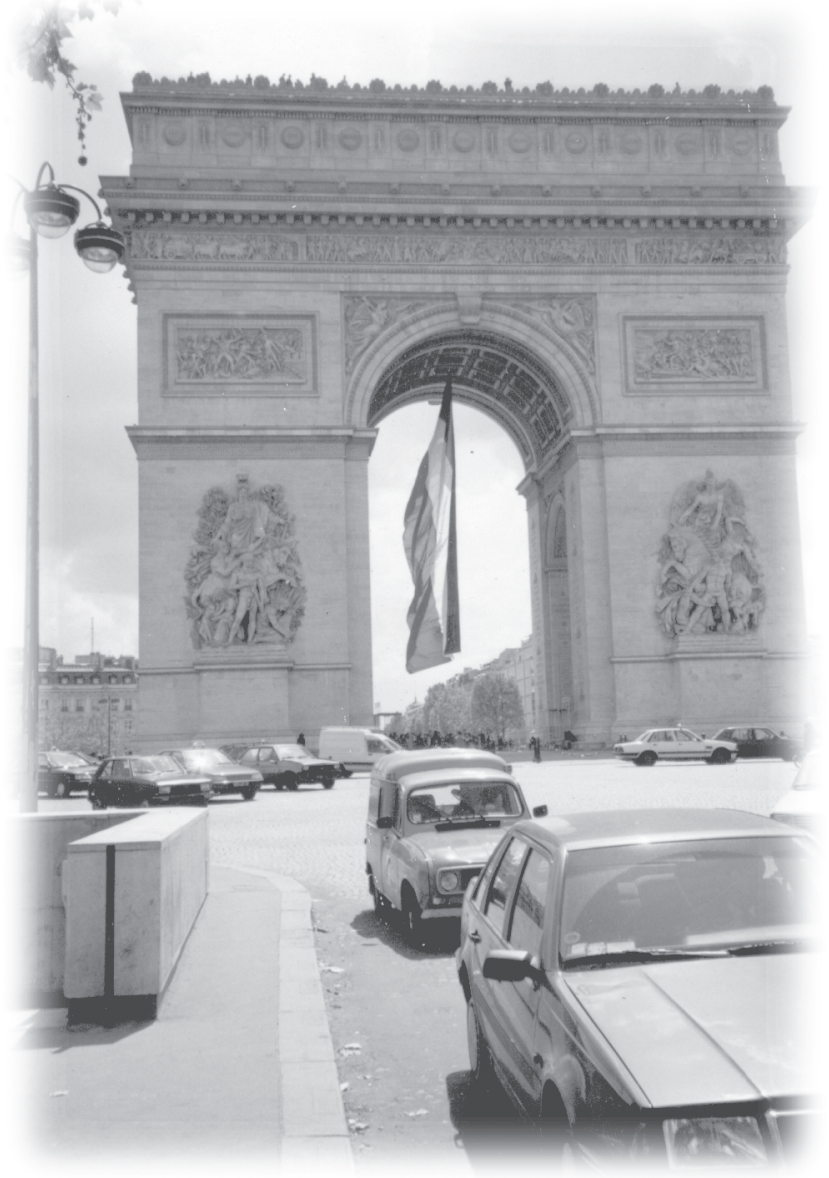

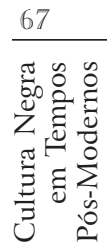

I - Arco do Triunfo - foto M. A. Luz, 1990 
A "nova ordem mundial" abrigava a guerra fria que se seguiu, e, pouco a pouco, a hegemonia anglo-saxônica iria se estabelecer.

Há 50 anos, em meio a esse contexto histórico, 50 signatários representantes dos governos de seus países proclamaram a Declaração Universal dos Direitos do Homem. Tentando consolidar os propósitos da ideologia humanista, na verdade ela constitui-se num ponto de referência no imaginário que percorre as relações sociais de produção do que se convencionou chamar de sociedade industrial. De um lado, os países socialistas vivendo a utopia comunista, de outro, os países capitalistas vivendo a utopia do mundo livre, da democracia e direitos humanos. A URSS mantendo seu império de um lado, os EUA e seus aliados de outro.

Em meio à guerra fria, guerras de libertação nas colônias - fixadas no enquadramento da ideologia dos Estados Nacionais, herança dos colonizadores - se processam sob a pressão da nova divisão geopolítica instalada. Mais do que nunca, se desenvolve a indústria armamentista, e o resultado da competição da guerra fria é que tanto a URSS quanto os EUA poderão agora destruir por mais de 60 vezes o planeta?!!!

Dourando a pílula, mais do que nunca, a tecnologia sustenta a ideologia do conforto e bem-estar proporcionados pelos "tempos modernos". A própria tecnologia, principalmente a da chamada indústria cultural e das telecomunicações, irão promover o mundo encantado. Proporcionará o mínimo de sociabilidade que irá garantir a sujeição voluntária das populações aos Estados Nacionais, que, sem dúvida, não se manteriam apenas pela força pública. Nesse mundo encantado, o trabalhador livre - ou em outras palavras, o sujeito produtor e consumidor - ganha suas garantias individuais, o direito de cidadania sustentado na Declaração Universal dos Direitos do Homem. Uma vez enquadrado no circuito da ordem da produção e consumo industrial, ele teria suas compensações pela sujeição voluntária - alimentada pelas utopias veiculadas por distintas pedagogias, dentre elas a dos valores cristãos, sobretudo do protestantismo. Mas o que ocorreu e o que ocorre é o desgaste das utopias que não conseguem mais manter a potência do mundo encantado da chamada sociedade industrial, sustentada pelos grandes impérios.

O sacrifício imposto pela corrida armamentista e "guerras localizadas", o perigo de destruição nuclear do planeta, o incrível desgaste da natureza - a mercê dos projetos e projeções da produção industrial -, os males sociais oriundos do modelo concentrador expresso pelas megalópoles geram indagações e perplexidades.

A utopia do homem moderno, o honnête homme, o cidadão, cercado pelo conforto, respeitador das leis, dedicado à família monogâmica e ao trabalho burocrático industrial, sujeito produtor e consumidor, se esvai pelas brechas e fissuras do Estado totalizante e concentrador, que exerce de um lado uma força de atração centrípeta, mas também centrífuga, lançando e mantendo à 


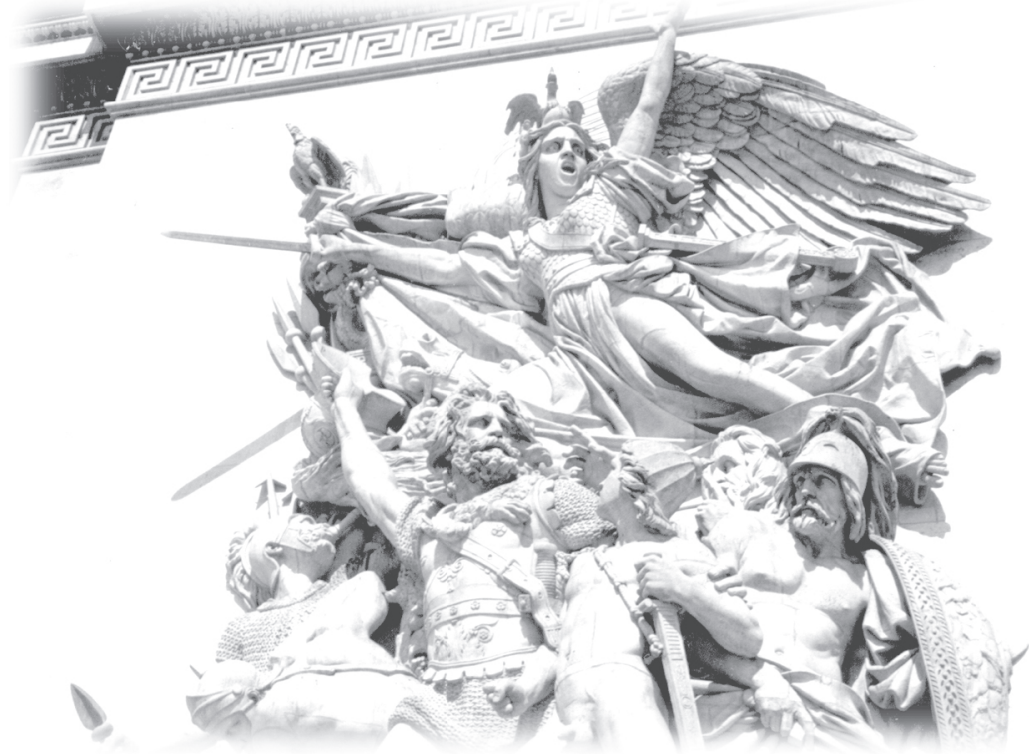

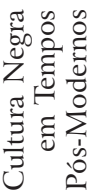

2 - Detalhe de escultura do Arco do Triunfo - foto M. A. Luz, 1990 
margem parcelas significativas da população. A queda do muro de Berlim simboliza o desgaste das utopias. Ele não caiu para um lado só. $\mathrm{Na}$ seqüência, a emergência de lutas de afirmação de identidade referentes a processos civilizatórios e formações étnicas recalcadas no âmbito dos Estados Nacionais passaram a expressar a crise que promoveu a implosão do contexto da guerra fria. Pluralidade étnica, cultural e civilizatória e, conseqüentemente, conflitos por novas divisões territoriais caracterizam o panorama do mundo contemporâneo. A preservação ambiental, em face à crescente poluição industrial, e o crescente e acumulativo poder de enlaçamento dos países imperializados e homogeinizados ao capital financeiro, gerando grave crises econômicas e sociais, são novas temáticas que vão para além da Declaração Universal dos Direitos do Homem.

Nos 50 anos da Declaração... é preciso novas reflexões que contemplem o reconhecimento das diversidades e pluralidades, no sentido de procurar a superação dos conflitos através do respeito à alteridade - não só referente aos distintos povos e civilizações, mas também incluindo o meio ambiente -, propondo, quem sabe, novos estatutos que possam reger a possibilidade de co-existência e convivência; erigindo novos princípios baseados na riqueza do Universo - que é a variedade da vida, de formas de existência e modos de existir que também caracterizam a sociabilidade humana. 


\section{IDI N`LA:BUNDA GRANDE GRANDE NBUNDA}

Volta e meia no nosso cotidiano, atravessado e trançado pela diversidade cultural civilizatória, enfim, por distintas linguagens e valores ocorrem discussões em torno da bunda, que se apresenta como um elemento simbólico de nosso imaginário social.

De um lado, senhores e senhoras puritanas, falsos moralistas etc, representam a repressão; de outro, uma larga maioria rebolante emerge incitando a liberdade louca do desejo.

$\mathrm{Na}$ versão brasileira da música de Cole Porter, cantada por Ella Fitzgerald, Elza Soares, com sua voz rouca afro-americana, canta; "leões ao léu, sob o céu, fazem..." e daí por diante, todos fazem, tudo recria, "vamos amar...".

Na dinâmica do ciclo vital, o já era combina-se com o por vir, o passado com presente-futuro, o poente com o nascente, o por de trás e o pela frente...

No mistério da fecundação e da gestação, estão inclusos os processos de ressarcimentos e restituições.

Desse modo, na tradição afro-brasileira, pode-se incluir a bunda como índice de visualização dos caminhos da genitália, e daí, portanto da fertilidade.Concepções correlatas elaboram o mistério da terra restituída, apaziguada, pronta para ser gestada.

Para nós, a origem da palavra bunda se desdobra de um povo bantu, os Mbundo.Os Mbundo, no início do processo colonial escravista português, formavam o reino do Ndongo, em território do que hoje compreende Angola, e tinham como rei a inesquecível rainha Nzinga ou Ginga, presente na memória das tradições afro-brasileiras como, por exemplo, no ciclo das congadas.

A importância histórica da rainha Nzinga está em que ela se tornou um baluarte na luta pelo fim do tráfico escravista e pela manutenção da independência do Ndongo frente ao reino português. 
A importância dela também emerge pela forma de luta por ela empreendida.No terreno militar se caracterizou, conforme os relatórios portugueses, como a 'rainha invisivel', que jamais se mostrava no teatro da guerra, sempre em movimento, saindo dos palácios e vivendo em kilombos, os acampamentos militares, em constantes ações de ataques e retiradas. No terreno político, nunca se recusou às conversações procurando através da diplomacia a almejada paz com soberania.

Dessa guerra de movimento e de atuação diplomática, nasceram no Brasil as filosofias da capoeira, primeiros movimentos básicos, a ginga, e também emergiu, em meio às negociações das irmandades católicas, a continuidade das tradições africanas.

Nas festas de largo, nos feriados católicos, acontece o congraçamento de comunalidade africana, rodas de capoeira, samba, congadas, etc.

Nelas o corpo em movimento escreve através dos gestos seu inesgotável repertório de expressão simbólica onde se "lê" sobre o ser, a vida, o mundo a existência, a coexistência...

No samba de roda, a umbigada, o requebrado, e o rebolado das "cadeiras' são movimentos culminantes que se combinam com o ritmo sincopado da percussão".

O samba de roda se caracteriza por sua sociabilidade aberta, processo dinâmico de interação dos participantes que se agregam, se individualizam e se reconhecem na convergência do requebrado.

“... baiana é aquela/que entra no samba/de qualquer maneira/que mexe, remexe/dá nó nas cadeiras/deixando a moçada com água na boca...”.

Geraldo Pereira foi mais um dos tantos cantores e prosadores que puseram num pedestal o movimento sincopado e provocante das "cadeiras" como parte romântica e brejeira de nossa identidade afro-brasileira, tendo como fundo um antigo rito africano da fertilidade.

A relação metonímica da imagem das "cadeiras" com a fertilidade aponta para elaborações do existir que se aprofundam em direção a angústia existencial.

Por isso a "bunda" condensa em sua imagem as perspectivas mobilizantes do receber e do devolver, do recriar, do restituir, do nascer, e do morrer.

Diante do medo do enfrentamento do mistério do desconhecido, duas reações deslocadas do contexto civilizatório, dos topus lugares que nos localizamos acontecem.

De um lado a exploração descontextualizada da imagem apenas erótica e exótica da bunda, nas artes, pintura, escultura, na literatura, na indústria cultural, na produção musical, dança, show business, envolvidos pela exploração comercial cujo ícone mais trágico disso tudo é o episodio da chamada "Vênus Hotentote".

Por volta do início desse ano de 2002, a imprensa mundial noticiou a tentativa de devolução dos restos mortais de Sartijie Baartman à África do 
Sul. 'Quando jovem ela foi seduzida a viajar para a Inglaterra e exibida em apresentações circenses para expor suas nádegas, tidas pelos ingleses como "extremamente desenvolvidas". Uma bunda para "inglês ver". Por sinal um povo "sem bunda", o que não quer absolutamente dizer sem ânus. ${ }^{2}$

Depois seus restos mortais foram mantidos em formol para pseudos estudos na França, e seu corpo moldado e exposto no Musée de L'Homme.Sara faleceu na miséria e 1835, e seus restos mortais, que somente agora the trouxeram a dignidade merecida foram expostos até 1982 na França iluminista, humanista!... "Macaco olha o seu rabo...".

Também descontextualizada é a censura de teor moralista puritana ou de disfarce intelectualóide, marxista-cristão-estalinista que se baseiam nas ideologias dicotômicas mente/corpo, alma/ matéria ou carne, consciência de classe/alienação e afins...

Para compreendermos o significado da bunda como elemento simbólico inserido na cultura afro-brasileira, no comportamento e no imaginário do povo brasileiro em geral é preciso reconhecer os elementos de elaboração de mundo que sua imagem abriga na tradição religiosa.

Só assim também compreenderemos melhor a motivação da censura na forma da denegação da alteridade e dos mecanismos de defesa na objetificação do outro, projetado como ser humano estranho, não semelhante, e, portanto passível de manipulação e exploração.



3- Mãe em Paris - foto M. A. Luz,1991. 
Isto porque a bunda é apenas índice cultural de elaborações mais profundas e por isso mais temidas.alcançadas pela religião.

Nas tradições religiosas africanas espalhadas também nas Américas, o mistério da gênese e do existir se articula inexoravelmente com o culto aos ancestres.

Por outro lado à ancestralidade se apresenta como um dos valores mais significativos da comunalidade ou sociabilidade.Quanto mais "filhos", mais o ancestral deverá ser lembrado e cultuado.Daí a importância da fertilidade como valor proeminente, apesar das dificuldades socioeconômicas que aqui e ali acoplam a vida das comunidades afro-descendentes em geral.

Parte poente do corpo, a bunda além de ser índice da genitália, do prazer e do gozo propiciatório da continuação da espécie, expresso como vimos nos sambas de roda; "bota a mão no lê lê lê", ela abriga também elementos do aparelho urinário e digestivo.

Esse aspecto da ingestão, circulação e restituição dos alimentos caracterizam também a dimensão do poder do orixá Esu, que na tradição nagô se apresenta especificamente como o Esu Bará, oba+ara o rei do corpo!. ${ }^{3}$

Na tradição nagô, como me narrou certa vez Mestre Didi Asipá, Alapini, a cabeça não pode passar sem a complementação das funções do ânus.

Além de ser patrono da ação, do movimento, da circulação, o senhor dos caminhos, Esu é patrono das relações sexuais, da interação entre princípios masculinos e femininos, caracterizando-se como terceiro elemento, o procriado o que permite o feto se alimentar e se desenvolver através do cordão umbilical e da placenta.

Por fim, e não menos importante quero fazer referência à simbologia do pano da costa como poder feminino.Ele nos lembra que a criança até cerca dos dois anos, na cultura negro-africana, é carregada amarrada às costas por sua mãe.Apoiada nas cadeiras, enrolada pelo pano, ela sente-se confortavelmente protegida de tudo e de todos.

Todas essas referências visam sublinhar um pouco o universo simbólico apaixonante que anima nosso cotidiano e alimenta nossa identidade.

\footnotetext{
${ }^{1}$ Cf.Suzanne Daley, The New York Times-Macabra Civilização-França Briga por Restos de Africana, in Jornal do Brasil0 1/02/02.

${ }^{2}$ Esse ponto da diversidade humana pode ser índice nas explicações das reações de estranhamento, que provocaram essa trágica situação: "Essa mulher foi tratada como se fosse alguma coisa monstruosa. Mas qual era a verdadeira monstruosidade?" Perguntava Nicolas About senador francês autor do projeto que devolvia à África do Sul os restos mortais de Sartijie Baartman.A verdadeira monstruosidade podese dizer, é a projeção das características do estágio da libido sádico-anal na cultura ocidental, principalmente no contexto do imperialismo-capitalista, sobre a imagem do outro, no caso da outra. A partir das obras de Freud o estágio sádico-anal se apresenta ligado ao erotismo provocado pela pulsão sádica de controle muscular e pela mucosa anal no que se refere à evacuação, a retenção e a destruição do objeto.Simbolicamente para Freud há uma equivalência entre fezes $=$ presente $=$ dinheiro.Se desdobrarmos essa referência, podemos tentar compreender porque a bunda que contém o ânus poderia mobilizar tanto
} 
os povos imperialistas que estão fixados, obsessivamente neurotizados, nessa fase de organização prégenital e que fantasiam seus desejos de controlar, retendo e agredindo (destruindo) Através do deslocamento sublimando para o plano político, as relações sádicas com as nações do mundo, acontecem através da equivalência geral de todos os valores, o dinheiro, isto é, através do enlaçamento da dívida externa e das ameaças militaristas de lançar bombas!

${ }^{3}$ Cf. SANTOS, E.Juana e SANTOS, M. Deóscoredes, ESU BARÁ LAROYÉ.

${ }^{4}$ LUZ, Aurélio Marco.Agadá: Dinâmica da Civilização Africano-Brasileira.Salvador: EDUFBA, 2001. 



\section{SUBVERSÃO SILENCIOSA}

O Desgaste do Poder Político na Pós-modernidade*

Atualmente, constituem-se novas reflexões sobre o contexto social que vivemos, assim como sobre suas projeções, que procuram compreendê-lo classificando este período histórico da humanidade de pós-modernidade.

Um dos aspectos destas reflexões refere-se às formas do político, no sentido ontológico do termo, isto é, as características do ser político, ou ainda, a dinâmica das formas que expressam num determinado momento a organização da vida social.

As indagações da problemática da pós-modernidade referem-se ao que Michel Maffesoli denomina de o Imaginário do Político. As reflexões sobre o Imaginário do Político constituem uma temática que procura responder portanto à indagação fundamental de qual a razão de ser da vida social, ou melhor, do ritmo de alternância de permanência e mudança dos vínculos sociais ou de suas formas.

A partir daí, outras indagações se desdobram - "Em que se funda a surpreendente longevidade da servidão voluntária? Ou, por outro lado, como se explicam as surpreendentes revoltas que regularmente pontuam as histórias humanas?"

Para responder a essas questões, é constituída uma trama conceitual de caráter filosófico e social baseada num novo contexto epistemológico de caráter interdisciplinar e plural. Um dos principais conceitos ou categorias utilizados é o da força imaginal, conjunto de idéias que compõem a visão de mundo e as aspirações de uma época que representa o espírito do tempo constituído inicialmente de uma bacia semântica de onde segue seu curso através do tempo.

A força imaginal de característica imaterial tem na forma religiosa a essência da necessidade ou da razão da vida ou dos vínculos sociais. Convém sempre lembrar a raiz da palavra religião que vem de re-ligare.

\footnotetext{
*Artigo publicado, em 1991, pelo Caderno Cultural do jornal A Tarde.
} 
Um retorno às bases inaugurais da Sociologia, uma releitura dos trabalhos de Emile Durkheim apontam para a pulsão religiosa como a fonte do desejo do estar junto que constitui a trama social alicerçada pela força imaginal. É a força imaginal, portanto, que garante a base do político, caracterizando a servitude voluntária, isto é, a aceitação da coerção, isto é, de hostilidade constitucional que sustenta o político. Político, no sentido de uma forma de organização social caracterizada por uma luta cotidiana atravessada pela paixão.

A origem da palavra político recai sobre o radical grego pólis, isto é, múltiplos, variados, muito. A pólis caracterizava a aglomeração da cidade. Quando todos os grupos da cidade se reuniam para comemorar Dionísios, divindade da fertilidade, da boa colheita, dimensão ecológica da vida social.

Entidades chetonianas, relacionadas com o mistério da terra, enraízam o político.

O chefe está a serviço da comunidade. A ele cabe fazer crescer a comunidade, obtendo a harmonia cósmico-social, que é a base da autoritas e, portanto, da servitude.

Neste sentido, pode-se dizer que não há política sem religião, isto é, religare, é manter a união fundada no compartilhar, das grandes paixões e mesmos sentimentos. Mas o início do poder político está caracterizado quando determinados grupos sociais tomam para si a responsabilidade de gerir a sociedade, o que era responsabilidade de todos. É o início das "chefarias", que contudo permanecem também responsáveis pelas nuances cósmicas. Aliás, a própria chefaria possui uma ligação cósmica, como ilustra o epíteto de Luiz XIV, rei da França, roi soleil, o rei sol.

A gestão do político passa a ser portanto a arte do político, isto é, da chefaria. O homem político é aquele capaz de gerir as paixões, e, para tanto, deve possuir um poder carismático, isto é, o de gerir a erupção do afeto na forma do político, possuir a virtu. Para bem gerir a paixão política, Maquiavel, nas Histórias Florentinas, aconselha que "é preciso aproveitar os períodos calmos do rio para fazer represas e modificar seu curso". Ainda nas Histórias Florentinas, ele se refere de uma maneira utópica à idéia de equilíbrio político, de virtu, isto é, a de que a cidade harmoniosa é aquela em que as lutas de interesse dos diferentes grupos que a constituem são capazes de se anularem entre si de modo a não haver dominação de uns sobre os outros.

A continuidade do poder político está, portanto, ligada à gestão da força imaginal, que por sua vez condensa a energia comunal que caracteriza o esprit du temps, o espírito do tempo.

Maffesoli insiste que o político, enquanto forma social, possui um enraizamento religioso. $\mathrm{Na}$ institucionalização do político, há sempre o lugar do sagrado. Citando Dumezil, ele ilustra essa situação através do mito fundador do Império Romano, referindo-se à história de Rômulo e Remo, que representam a realidade material e imaterial da força vital, respectivamente. Dois aspectos do poder, imperial e religioso. 
É, porém, o aspecto religioso, isto é, a força imaginal, que sustenta a rede de alianças das comunidades que formam a sociedade, isto é, o político, ou melhor ainda, a aceitação da coerção política. Essas dimensões que aproximam o poder político da potência das alianças comunais, que passam pela ligação vida social-natureza.

O mecanismo de comunicação, tendo, de um lado, o poder político e, de outro, a potência comunal se dá através do esmaecimento da alteridade, isto é, os vários outros dão lugar ao surgimento do Outro. Entretanto, é a potência comunal que sustenta ou suporta a força imaginal. Em nível da força imaginal, o aparecimento dos Estados-Nações procurará dividir radicalmente homem e natureza. O retorno da mãe terra, o grande útero, é substituído pela idéia do Estado-Nação, uno, totalizante, pedagógico, unidimensional.

Diferente da Paidea, que caracteriza, num determinado contexto histórico e social, a formação do homem grego, que é uma iniciação cultural global onde o político se caracteriza como um encargo da organização social, na relação poder-saber; no Estado-Nação, positivista, moderno, a formação se caracteriza por uma pedagogia reguladora, visando ao que é bom para o serviço público. O serviço público aqui, é constituído pelos especialistas da cidade, isto é, os proprietários do poder, que acabam por aprofundar a distância entre a vida social e a política, a burocracia; entre a potência comunal, de um lado, e o poder político, de outro.

Neste contexto, a pedagogia é apresentada no âmbito da ideologia do serviço público, isto é, educar é tomar a criança pela mão e controlá-la e conduzi-la no sentido do que é bom para o serviço do público.

Usando categorias da Sociologia de Pareto, Maffesoli expõe que o poder político se caracteriza por uma força centrípeta, atraindo para o centro toda a forma de vida social. Mas, quanto mais ela atrai, ou é atrativa, maior é a faixa de potência comunal que age de forma centrífuga, afastando-se do centro do poder, situando-se à margem.

Como exemplos históricos importantes, ilustrativos desta situação, podese citar o joaquimismo, a reforma luterana nos seus primórdios, a revolução francesa, etc.

Nestas situações, percebe-se uma saturação do imaginário, onde se dá sempre lugar para uma desordem plural, onde a força imaginal, sustentáculo das alianças, pulsa no sentido de criar um novo éthos comunitário, no sentido de refundir e estabelecer novas formas de um estar junto.

No imaginário destas ações, o sacrifício, isto é, a morte ritual-política da chefaria acontece. Para a criação do novo é preciso que o sangue corra. Também o fogo, que representa no plano imaginário a origem do estar junto, a reunião em torno da fogueira, faz parte atuante das revoltas, propiciando o novo. Todavia, se a paixão e o imaginário triunfam num momento, noutro há o triunfo do "realismo" sobre o imaginário, como ilustra o período napoleônico ou a nomenclatura de Stálin. 
Conforme Maffesoli, é como se a vida social fosse historicamente marcada como um pêndulo, por uma dialética envolvendo princípios dionisíacos e prometéicos. É no âmbito desta problemática epistemológica que se enquadra a divulgada temática da passagem da modernidade à pós-modernidade.

A modernidade representa um momento predominante prometéico do esprit du temps, ao contrário, a pós-modernidade representa a predominância dionisíaca.

A pós-modernidade resulta da saturação do imaginário positivista, produtivista da modernidade. Sua força imaginal ou potência comunal é incapaz de continuar atraindo para o centro do poder, atuação centrípeta da ordem política, o conjunto social.

Por outro lado, a conseqüência do movimento centrífugo que se desenvolve é a ampliação da margem social ao poder político, que forja novas experiências estéticas, um novo sentir comum partilhado, um novo vivido social, um cotidiano, enfim, que reveste o Estado do povo, afastado do Estado oficial.

Como dizia Nietzsche, "as verdadeiras revoluções caminham a passo de pombo". Neste contexto, a margem tende a predominar, constituindo uma autonomização da vida social.

Deste movimento resulta o fim da servidão ou obrigação voluntária, o poder político perde sua essência, isto é, a potência da força imaginal que sustenta a ligação da institucionalização do poder.

Um processo de anomia se desenvolve no político. Todavia, esse processo não se generaliza pela sociedade toda, pelo contrário, é uma nova forma imaginal que se está constituindo pelo vivido da base da margem, novas formas de organizar o estar junto comunal no plano social.

Maffesoli aponta como exemplo do que se pode chamar da implosão do poder político da modernidade, o que vem acontecendo na Europa do leste. A força imaginal constituída pela idéia generosa do comunismo esvazia-se cotidianamente, até que o poder político se desfaz. O desgaste do poder progride como um curso d'água, e, simultaneamente, ocorre a autonomização do conjunto de vida social. Nova forma imaginal se elabora, pequenas utopias vividas, dia-a-dia, em nível cotidiano, vão-se estruturar em discurso, realimentando a energia coletiva.

Epifenômenos do esprit du temps da pós-modernidade, por outro lado, são observados como o desgaste do poder político através do processo de abstenção, a ironia e o cinismo ambiente envolvendo a autoridade e, em relação a ela, o que conota um desejo de condenação à morte do poder. Há, por todo lado, momentos de subversão, e esta avança mascarada.Pequenas tribos misteriosas vão constituir uma nova forma de agregação, partilhando sentimentos místicos conjuntamente. Enfim, a aceitação da pluralidade cultural que se manifesta cotidianamente em múltiplas identidades sociais, ao mesmo tempo que o sentimento místico, o discurso mítico e nova forma de relação com a natureza voltam a envolver a experiência vivida - doxa caracterizando novas utopias, nova força imaginal. 


\section{PAINEL PLURALISTA Pós-modernismo e Política*}

O livro organizado por Heloísa Buarque de Holanda ${ }^{1}$ está a altura desta conhecida intelectual, sempre sintonizada com as novas e conseqüentes movimentações culturais.

Desta vez, é o movimento pós-modernista que é divulgado através de diversos ensaios repletos de informações deste pensamento atual nesta época de surpreendentes mudanças no panorama político mundial.

Heloísa organizou pós-modernismo e política dando uma ordenação temática capaz de formar um painel que possibilita ao leitor assimilar a contextualização e o significado do que se caracteriza como pós-moderno.

Essa ordenação temática inicia-se com um ensaio de Andreas Huyssen sobre a localização, gênese e significado do pós-moderno, distinguindo-o do que se classifica como modernismo "nos mais distintos aspectos, como no campo das artes, da arquitetura, enfim em variados campos da 'cultura' em geral, como é entendida no âmbito da intelligentzia do chamado primeiro mundo de forma detalhada e erudita". Mas o mais importante para nós é quando destaca uma das características do pós-modernismo, ou seja, a de que "há uma crescente consciência de que outras culturas, não européias, não ocidentais, devem ser abordadas por meios que não os da conquista e da dominação"... e que os da fascinação erótica e estética com o "Oriente"...

No mesmo sentido de produzir uma gênese do pós-modernismo, sobretudo de um pós-marxismo, caminha o ensaio de Frederic Jameson. Ele sublinha que a práxis marxista gerou profundas alterações teóricas de conseqüências estratégicas significativas. As concepções de dialética complexificada de Mao-Tse-Tung, que resultou da revolução camponesa e propiciou a revolução cultural chinesa, promoveu e promove outros

\footnotetext{
* Resenha publicada, em 1991, pelo Caderno Cultural do Jornal A Tarde.
} 
movimentos não esperados. A teoria da hegemonia do poder de Gramsci, da estratégia do foco de Guevara, retiraram da contradição burguesia x proletariado, e do conceito de classe, a rígida primazia da realização da mudança social. As concepções de Althusser da autonomia relativa das estruturas sociais, do mesmo modo, deslocou a instância econômica da cena principal no pós-marxismo, mesmo que o FMI tente ocupar o espaço que o império britânico ocupou na modernidade.

Para o pós-marxismo, entretanto, os novos sujeitos históricos, sua resistência, não escaparia a forma da luta de classe. Pode-se, portanto, dizer que o pósmarxismo mantém-se nos limites da modernidade. Neste mesmo sentido, constituise a abordagem de Ernesto Laclau. Eé contrariando esses limites que se constitui o ensaio de Stanley Aranowitz, sobretudo por que, referindo-se a um novo paradigma pluralista de constituição do poder, avesso às construções de bases estruturais, dá relevância a variedade de segmentos sociais atuantes, assim como a relatividade da atuação de segmentos similares em contextos diferentes, o que distingue a especificidade de cada qual. Tudo isso faz com que afirme...

Os novos movimentos sociais têm-se oposto a estas fórmulas ao insistir em que são agentes morais e políticos por direito próprio, que o discurso desses movimentos é uma alternativa aos discursos marxista e liberal e que sua concepção das relações cotidianas não só difere como pode contradizer aquela dos discursos políticos ideológicos tradicional e liberal.

A partir deste ponto, os ensaios passam a tratar desses outros sujeitos históricos que caracterizam o panorama pós-moderno e que tem na luta pelo fim do colonialismo, latu sensu, um dos fatos marcantes do fim da modernidade.

Horni K. Bhabha procura nas fronteiras conceituais do Ocidente abordar a questão do outro, para além das análises de diferenciação de classe e gênero, na margem colonial, texto limite da representação da problemática cultural e “racial”. É aí que se pode constituir uma percepção das construções discursivas e físicas do poder discriminatório.

É aí que se pode ultrapassar os limites epistemológicos da modernidade das oposições forma/conteúdo, essência/aparência, ideologia/ciência, para se caminhar pelas sendas do saber/poder, sobretudo pelo fato que o saber colonial se caracteriza pela constituição de fetichização de estereótipos garantidos e reproduzidos pelo aparato institucional. É neste âmbito que é preciso fazer a anatomia do fetiche do estereótipo, ao qual "colonizado e colonizador" estão aprisionados pelas formas de identificação narcisistas e agressivas disponíveis no imaginário.

Todavia, a superação do paradigma colonial da discriminação forma uma corrente com outros paradigmas de constituição dos estereótipos em relação ao outro. É neste terreno de complexidade da constituição das identidades e das diversidades, em meio ao cenário das fantasias coloniais que caracteriza-se essa abordagem. 
Para além desta problemática que chamaríamos da constituição do recalque, o ensaio de Henry Louis Cates Jr. sobre A Crítica do Signo e O Macaco Significador, nos parece o de maior importância, exatamente porque tenta perceber a diversidade a partir do respeito a alteridade própria na medida que procura ler e entender o discurso do outro.

É assim que a partir do conceito de macaco significador do acervo cultural afro-negro-americano, aproximado ao conceito de Exu na mitologia nagô, pode-se superar a problemática do signo desenvolvida pelas teorias da linguagem no Ocidente a partir de Saussure, ultrapassando os limites da dicotomia significado/significante, indicando que a significação é absolutamente contextual. As conseqüências disso são enormes, e, por exemplo, pode permitir a compreensão de toda a trama da continuidade da linguagem e identidade negra num contexto que através do recalque, provocou tantas divisões num ser que constituiu um modo de ser afro-americano-jazzístico. A temática da pluralidade humana e da alteridade continua no ensaio de Jane Flax, que faz reflexões sobre a categoria de gênero na teoria feminista.

A ambivalência do gênero enquanto categoria, é que ao mesmo tempo que instala um espaço de afirmação da diferença, por outro lado pode aprisionar o discurso feminista neste limite, e, este limite só pode ser superado no contexto pós-modernista, que absorve a multiplicidade dos grupos humanos e da natureza. Neste sentido, o movimento feminista como elemento de desconstrução da modernidade possui uma eficácia transcendente.

Finalmente, o texto de Edward W. Said sobre o orientalismo, envolve a necessidade de superação dos obstáculos ideológicos da modernidade, do recalque que encobre o real significado do Oriente.

Deixando este ensaio para o encerramento, que aponta o cruzar fronteiras interdisciplinares e discursivas da pós-modernidade como caminho, parece haver uma intenção conclusiva de que o aspecto emergente de maior riqueza do pós-modernismo é o voltar-se para a pluralidade humana. Esta dimensão do pós-neo-colonialismo implica no respeito ao outro em sua integridade. O que foi fonte de dominação e exploração do trabalho e riquezas econômicas desenfreadas, é percebido como fonte de enriquecimento do viver e do existir.

Para nós, brasileiros, porém, que desde sempre vivemos e existimos na tensão permanente da pluralidade civilizatória de valores que constituem a nacionalidade, essas mensagens já estavam contidas no enigma pós-moderno precursor de Oswald de Andrade - Europa, França, Bahia.

\footnotetext{
Notas

${ }^{1}$ Hollanda, Heloísa Buarque, org. Pós-Modernismo e Política, Ed. Rocco, Rio de Janeiro, 1991.
} 



\section{O SEGREDO E O SAGRADO*}

A temática da pós-modernidade, no âmbito das ciências sociais, tem no CEAQ - Centre D'Etudes de L'Actuel et du Quotidien, Paris V, Sorbonne, dirigido pelo Professor Michel Maffesoli, uma instituição voltada para o intercâmbio e - a pesquisa que dão continuidade e aprofundamento a renovação contida neste novo campo do discurso acadêmico com seus característicos desdobramentos.

Dentre as atividades desenvolvidas no decorrer deste ano, sobressai o colóquio sobre Roger Caillois.

O colóquio se constituiu numa espécie de tributo dos filósofos e cientistas da pós-modernidade à um intelectual que foi precursor do uso de noções e categorias que marcam essa problemática do pensamento social atualmente na França e em outros países.

Diversos participantes abordaram distintos aspectos do significado da obra de Caillois, dando no final uma idéia bastante expressiva da totalidade de seu pensamento e a dimensão de sua projeção na atualidade o que procuramos relatar resumidamente.

Caillois, quando tinha seus vinte e poucos anos, esteve presente no surgimento do movimento surrealista, cujo impacto estético e cultural foi marcante na Europa e em outros continentes. Foi neste contexto que participou como um dos fundadores da Sociedade Secreta College de Sociologie, juntamente com C. Bataille. Esta Sociedade que existiu por volta de 1937 e 1939 , procurava em última instância propiciar e sentir a potência do sagrado que emerge da fusão do indivíduo na natureza, através da dimensão cosmogônica ou da intuição cosmogônica que é uma virtude Dionisíaca.

Através do segredo do ritual, se ligam e se constituem os vínculos comunitários, e é neste ponto nodal que se baseia a sociologia do sagrado que

\footnotetext{
*Artigo publicado, em 1991, pelo Caderno Cultural do Jornal A Tarde.
} 
caracteriza a obra desses autores, que convém sublinhar, foram influenciados pelos contatos existentes na modernidade com as formas sociais da tradição negro-africana.

Com a eclosão da segunda guerra mundial, o College de Sociologie cessa de existir. Caillois se retira para a América do Sul, precisamente para a Argentina.

Seu retorno à França, no pós-guerra, se dá num contexto em que a inteligência elabora diversos humanismos, todos eles embricados no terreno sociológico característico da modernidade, isto é, nos limites da "racionalidade" e da produtividade, seja o personalismo, o existencialismo, o marxismo, etc.

Neste contexto, não há lugar para uma problemática que aponta para uma concepção mágica da história.

Por outro lado, foi esta concepção uma das poucas capazes de avaliar corretamente o fenômeno do nazismo e do hitlerismo, ressaltando o significado das dimensões do sagrado, do ritual e do lúdico na performance política de um líder carismático, sua eficácia na condução das massas, o que era completamente minimizado pelo pensamento social que procurava esvaziar a presença do sagrado no âmbito das relações sociais.

Caillois percebeu esta ação de esvaziamento apontando para a produção cinematográfica norte-americana, em que diversos filmes apresentam cenas do morto diante de um juízo final em que o julgamento se processava da mesma forma que uma avaliação burocrático-empresarial.

O mistério e o maravilhoso são aspectos da vida social ressaltados por Caillois para marcar as raízes profundas da existência coletiva, o que gera um voltar-se voluntário para o aspecto transcedente da potência social.

Convém insistir que se a América do Norte aparecia como algo distante para a produção intelectual francesa de então, mais ainda a América do Sul, que influenciava com suas formas de existência social as concepções da sociologia do sagrado constituída através dos ensaios precursores de Caillois.

A falta de repercurssão do pensamento de Caillois também deveu-se a forma de divulgação, isto é, através de ensaios e não de livros, ou grandes livros o que geravam argumentos depreciativos à sua projeção,

- "Porque nos convencermos que quando estamos despertos não estamos sonhando?"

Para Caillois, o imaginário, o sobrenatural, não é apavorante nem espantoso, ele faz parte das coisas do mundo cotidiano, e mesmo, dá ordem e sentido.

No momento que o pensamento europeu moderno primava pela lavagem do sagrado, eis que o sagrado está presente em tudo e, sobretudo, no contexto da guerra. 
A guerra que engloba o sagrado, o jogo, o fantástico. O jogo carnavalesco da guerra, caça-caçador, o medo e a coragem frente à morte, à sedução da vertigem, do desfazer-se, contradições inerentes ao existir. Não há civilização sem jogo, esta dramatização da tensão de ter ou não ter medo. Essa pontuação ritual do jogo aproximado do sagrado. O tocar ou não tocar o objeto sagrado, ação constituinte do mecanismo de purificação.

Distintamente de Bataille, porém, para Caillois o jogo é diferente do sagrado. O conteúdo marca a distinção, e a transcendência do sagrado se caracteriza pelo seu conteúdo.

Todavia, essa distinção não deixa de conferir um papel de importância ao jogo no que se refere as relações que estabelece na dinâmica social. Caillois sublinhou que o lúdico é elemento estruturador das relações sociais cotidianas. O lúdico expressa aspectos da libido, da potência social, e exatamente por que lhe é dado pouca importância, por que é visto como insignificante, que pode tecer cotidianamente o laço social.

O lúdico é o enfrentamento do trágico, do cumprimento do destino, é uma forma homeopática de lidar com o destino, isto é, com uma dimensão da morte. O jogo atravessa a vida social e a caracteriza como teatro mundi do cotidiano.

Porém, sem dúvida, é o lugar do segredo e do sagrado, na constituição dos vínculos sociais, que marca a significação da obra de Caillois e sua projeção na atualidade da sociologia da pós-modernidade. 



\section{ARKHÉ E AXEXÉ Linguagem e Identidade*}

As comunidades-terreiro, egbé, se constituem em bem organizadas instituições compostas de um espaço sócio-religioso e arquitetônico próprio e caracterizado por uma população flutuante de seus membros que ali comparecem conforme determinada temporalidade litúrgica.

Os limites da comunidade estão caracterizados pela frase "da porteira prá dentro, da porteira prá fora" que procura estabelecer as relações do éthos negro-africano do egbé com a sociedade oficial europocêntrica.

Esses limites sempre são colocados para caracterizar o âmbito de atuação de poder entre ambos os contextos sociais. Todavia, a porteira funciona apenas como metáfora de limites, posto que a referência geográfica não traduz o alcance real dos processos de desdobramentos espaço-temporais do egbé que atua e se desdobra de diversas formas na formação social brasileira como um todo.

O egbé concentra o saber e poder religioso renascido a cada rito.

Os ritos se caracterizam pela linguagem que os expressam constituindo o que poderíamos denominar de estética sacra negra e que se realizam através de uma comunicação da participação.

Toda a produção estética material ritual, a visão de mundo, elaborações científicas e filosóficas, que se realiza num aqui e agora, e os comportamentos referentes a hierarquia institucional constituem um éthos negro que mantémse em contínuo desdobramento no Brasil.

Linguagem, comunicação, éthos, caracterizam desde o egbé, a identidade negra nacional.

Esta identidade negra não se caracteriza apenas pelo continuum negroafricano, mas por sua forma própria de reposição no Brasil, desenvolvendo

\footnotetext{
*Extrato de tese de doutorado, Agadá Dinâmica do Processo Civilizatório Negro no Brasil, 1985.
} 
uma forma própria de relações sociais, valores e linguagem características e originais.

Essa forma, contudo, está ancorada nos egbés tradicionais conforme se refere Muniz Sodré:

A expansão dos cultos ditos "afro-brasileiros" em todo o território nacional (apesar da diversidade dos ritos ou das práticas litúrgicas) se deve à persistência das formas essenciais em pólos de irradiação, que são as comunidades-terreiros (egbé). É isto que faz com que um santo da Igreja Católica (como S. Jorge) possa ser cultuado num centro de Umbanda, em São Paulo, como Ogum, orixá nagô. Ou seja, o conteúdo é católico, ocidental, religioso, mas a forma litúrgica é negra, africana, mítica. Ao invés de salvação (finalidade religiosa ou católica), o culto a S. Jorge se articulará em torno do engendramento de axé.

É neste sentido que o pacto semântico e a rede de alianças que formam o povo de orixá ou "povo-de-santo" possuem nos egbé tradicionais a sua arkhé categoria utilizada ultimamente nos trabalhos de Muniz Sodré, Juana Elbein dos Santos e Deoscoredes M. dos Santos.

A arkhé, todavia, não se restringe a um princípio inaugural históricosocial e cultural, mas engloba a energia mística constituinte da ancestralidade e das forças cósmicas que regem o universo na interação dinâmica de restituição de axé do aiyé e do orun deste mundo e do além e vice-versa ao contrário.

Se o ritual caracteriza um éthos, isto é, o aspecto da linguagem, estilo ou forma de comunicação e expressão de valores estéticos e éticos e conteúdos de saber ou de não saber, porém, o que ele realiza e dinamiza sobretudo é a restituição e transmissão de axé.

O éthos, que está presente nas relações estabelecidas com as matérias, substâncias e formas significantes dos preparos de folhas, dos líquidos para banhos e bebidas, da culinária, dos ileke, colar de contas, cores, cantos, vestuário, gestos, música, dança, palavra poética, cabeças e corpos viventes, constituídos em códigos semânticos, linguagem; se caracteriza por expressar e comunicar a mobilização de uma força latente, um "eidos", presente no conceito de axé, poder de realização.

A identidade constituída pela prática litúrgica transborda do plano imanente para a transcendente.

Um omo-orixá exprime uma identidade mítica ancorada numa arkhé e assentada num "eidos" caracterizada por um éthos.

Não é, portanto, apenas o éthos, característico do modo de vida das comunidades terreiros, que irradia princípios existenciais constituintes da cultura negra que estrutura a identidade histórica e social do mais significativo segmento populacional nacional. É sobretudo o seu "eidos", a sua dimensão transcendente atualizado no aqui e agora das relações sócio-litúrgicas do egbé. 


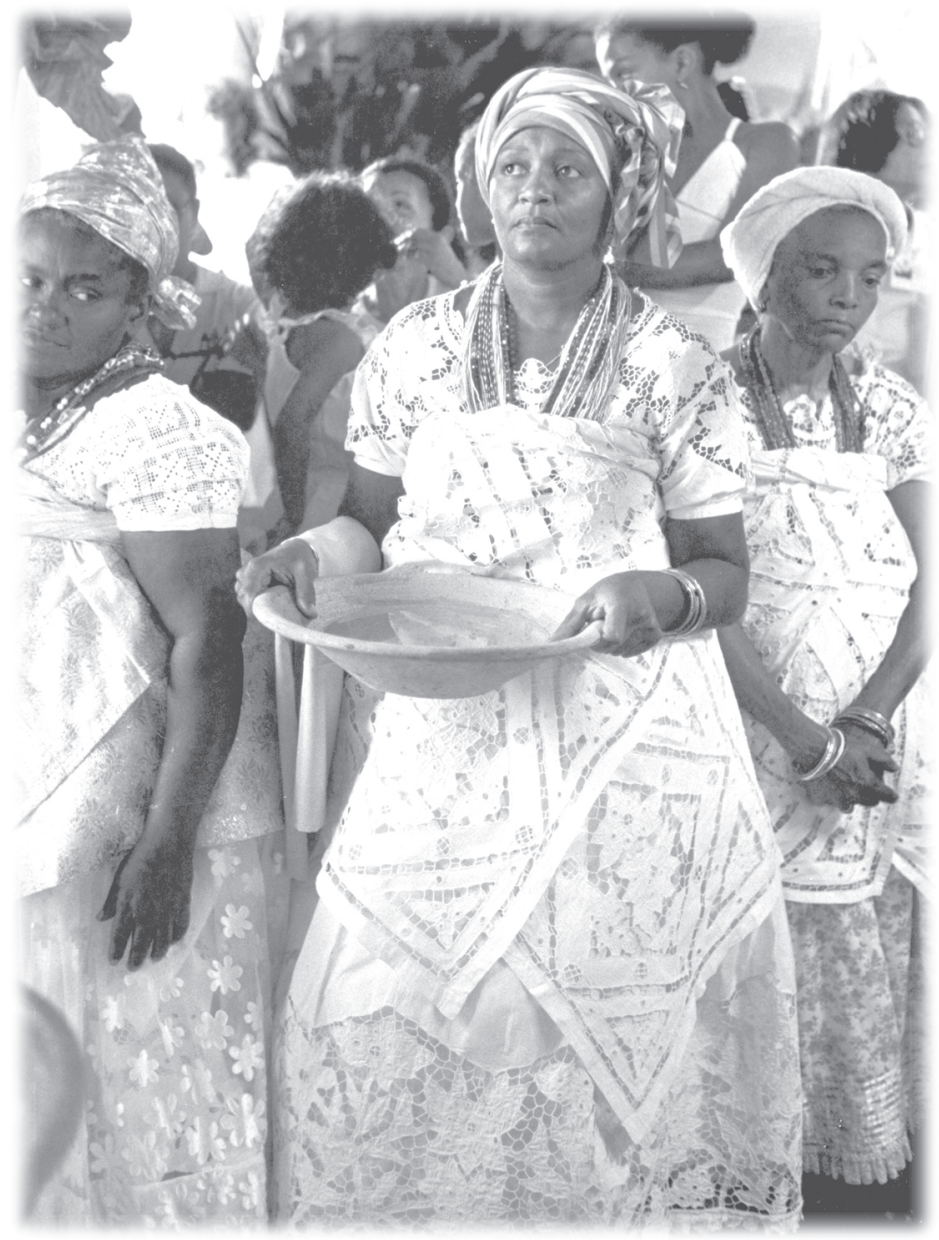

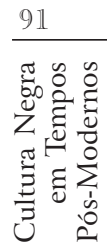

4 - Sacerdotisas do Ilé Iya Omi Axé Iyamasse, durante a recepção à II ${ }^{a}$ Conferência Mundial da Tradição dos Orixá e Cultura, Salvador - foto Arthur Ikissima, 1983 
O bantu não é um ser sozinho. E não é bom sinônimo para isso dizer que ele é um ser social. Não, ele sente e se sabe como uma força vital, como estando em relação íntima e pessoal com outras forças que atuam acima e abaixo dele na hierarquia das forças. Ele sabe que ele próprio é uma força vital, capaz de influenciar algumas forças e de se influenciar por outras. Fora da hierarquia ontológica e da interação de forças não existe ser humano, nas concepções dos bantu. ${ }^{2}$

Poderíamos generalizar essas observações de Tempels para todo o homem negro-africano tradicional, incluindo o que expandiu sua continuidade existencial no Brasil.

O desenvolvimento e expansão do axé no Brasil está ligada à reposição da continuidade africana.

A arkhé se refere aos princípios inaugurais que "imprime sentido e força, direção e presença à linguagem”. Neste sentido, é que os bantu também se referem ao muntu como "a força de conhecer" ("udi na Buninga bwa Kuyuka", em língua Kiluba). E os nagô são cientes de que o conhecimento efetivo depende da absorção de axé." ${ }^{3}$

Nesse sentido, também a linguagem e a comunicação, no âmbito do egbe, se caracterizam numa experiência iniciática, onde a presença dual ou grupal se faz necessária, pois o axé transmite-se através da pessoa que o detém em seu ser concreto individualizado.

Este ser individualizado, como vimos, porém, é imanente e transcendente. Um filho de Xangô tem Xangô como sua força consigo, mas Xangô é força invisível, transcendente, é um ser do orun que se apresenta no aiyê através do seu axé, de sua particularidade de força materializada no ser humano, no trovão e no raio, no fogo e em todos os elementos que recebem seu axé, no colar de contas, nas pedras do altar, etc.

No ser humano, o axé do seu orixá se transmite através do contato, da comunicação, do hálito, da fala, da interação ritual, aumenta e diminui.

Foi trazendo Xangô consigo que a Iyanassô instala na Bahia o axé que marcará o início do culto aos orixás, conforme a tradição do antigo império nagô, conjuntamente com o axé dos membros da família Axipá e outras sacerdotisas e outros sacerdotes fundadores, marcos de ancoragem, princípios inaugurais da herança negro-africana no Brasil.

$\mathrm{O}$ culto aos ancestrais se inicia ritualmente pela passagem ou restituição do morto do aiyé para o orun.

$\mathrm{O}$ ancestre possui seu lugar na comunidade, seja em seus assentamentos como Iya Agba, as mães anciãs veneradas no ilê ibo aku, conjuntamente com os Esa ancestres masculinos do culto aos orixá, seja em assentamentos e aparições como Baba Egun, Pai ancestral, cultuados nos ilesaiyn dos cultos dos ancestres masculinos que são os que foram iniciados no sacerdócio como Ojé. 


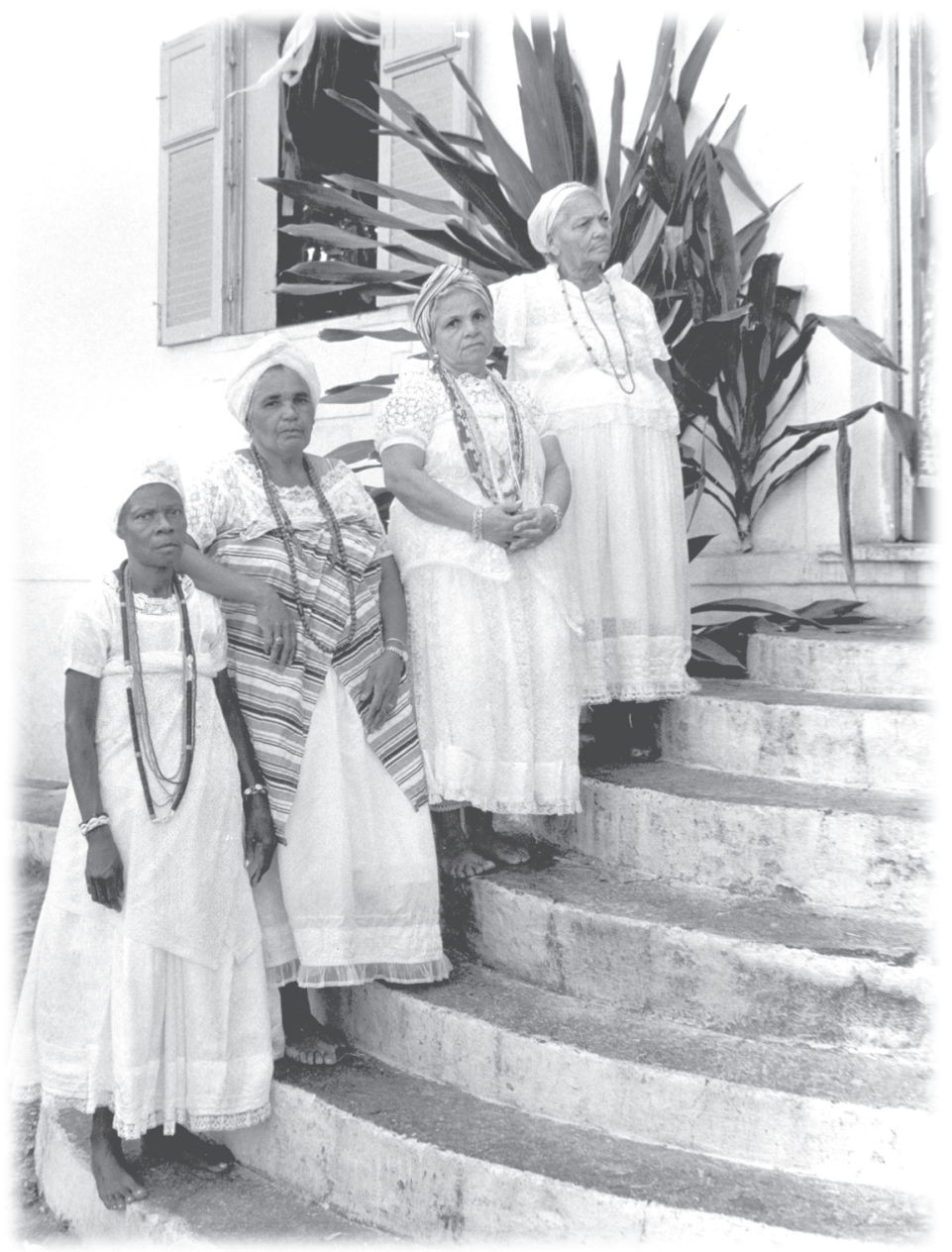

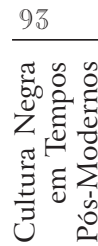

5 - Sacerdotisas do Ilé Iya Omi Axé Iyamasse, durante a recepção à II ${ }^{\mathrm{a}}$ Conferência Mundial da Tradição dos Orixá e Cultura, Salvador - foto Arthur Ikissima, 1983 
O rito que caracteriza a passagem do estado de vivente para o de morto se denomina axexé.

Quando morre um integrante do egbé, para possibilitar sua passagem para o além e reacomodar os laços da comunidade, são celebrados uma série de ritos mortuários, cujo ciclo completo se denomina Asésé. Ao mesmo tempo despede-se do morto e se reverencia a todos os Asésé, os primeiros ancestrais, o começo, a origem do universo, de linhagens, de famílias, de um "terreiro."

Todo integrante do egbe quando morto deverá ter seu rito mortuário, o axexé, e se converte num Axexé, uma referência, da continuidade ininterrupta da tradição.

Quanto mais alto o grau de iniciação, mais experiência e conhecimentos fixados e repartidos, mais reforçará o arkhé grupal, o ásé, o poder e energia mítica da comunidade.

O morto convertido em ancestre, em Axexé, possui lugar destacado na liturgia. São eles que, se constituindo em referências aos princípios inaugurais dos valores e linguagem do egbé presentificam num aqui e agora a expansão e a continuidade da comunidade.

IYa mi Asésé!

Baba mi, Asésé!

Esse oriki (poema), indica portanto, com todas as letras, que os ancestres são princípios inaugurais que permitem o realizar-se ritual num aqui e agora em que são homenageados e saudados.

Em todos os rituais da liturgia nagô sempre são invocados e saudados para atuarem no sentido de propiciarem a circulação de axé, realizando a dinâmica entre o orun e o aiye, este mundo e o além.

Os cânticos e poemas, as palavras, o som, os gestos, o vestuário, a oferenda, não possuem porém, apenas um conteúdo semântico caracterizando um éthos, mas também acionam uma norma transcendente que atualiza as relações entre o orun e o aiyé.

São enfim essas relações que representam a peculiaridade do ser do grupo.

Mo juba
Gbogbo asésé tinu ara
Saúdo e venero
A todos os Asésé, nossas origens,
Contidos em nosso corpo comunitário. 
A existência e a expansão da comunidade é garantida pela presentificação e recriação permanente das origens, ou melhor, as origens, sua presentificação e recriação permanente garantem o existir da comunidade, do egbé.

Bíbi bíbí lo biwa

Nascimento do nascimento que nos traz o existir. ${ }^{7}$

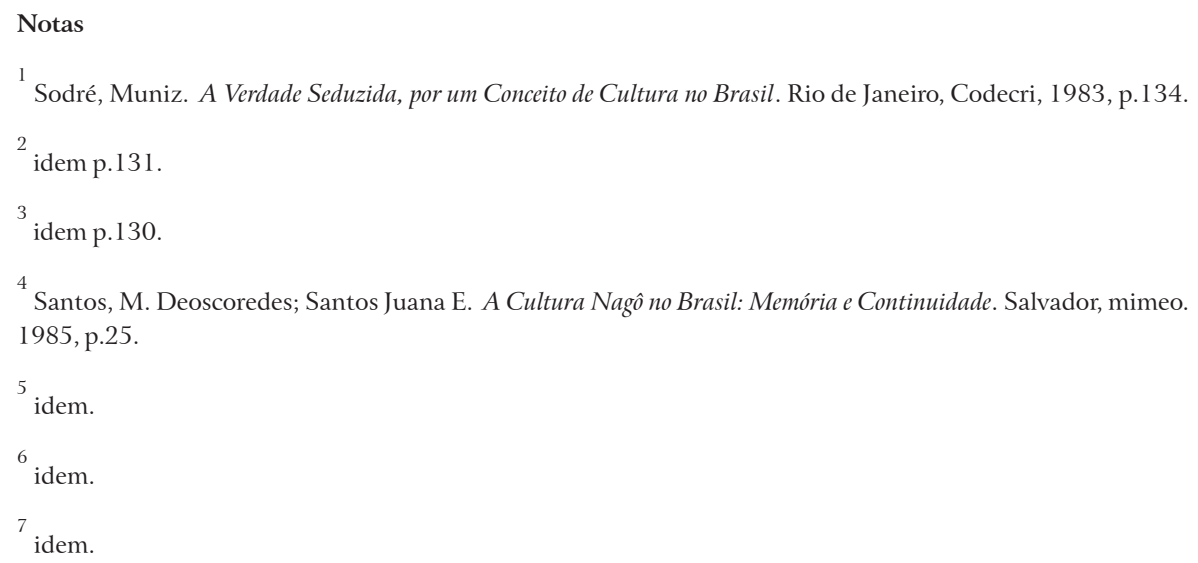





\section{IPORI E ELEDÁ A Propósito da Polêmica sobre o Dique do Tororó}

Conta-se que quando Orixá nla, Oxalá, o grande orixá, foi criar os seres humanos, ele recorreu e convocou todos os demais orixá para ajudá-lo a encontrar a matéria primordial para sua criação. Depois de muito procurar, encontraram a lama e viram que ela possuía as qualidades moldáveis que Orixá nla necessitava. Tiraram-lhe pedaços, mas logo observaram, constrangidos, que a lama chorava, vertendo água pelos pedaços arrancados.

Preocupados, devolveram a ela os pedaços e resolveram continuar procurando. Foi quando Iku, orixá Morte, não teve dó. Pegou um pedaço e dirigiu-se de volta a Oxalá, e todos os demais orixá o seguiram. Lá chegando, apresentou o grande achado, e Oxalá ficou bastante satisfeito e agradecido, dizendo que agora poderia iniciar sua missão. Os orixá, ainda preocupados, disseram então o que se passara - que a lama ficara chorando.

Oxalá pensou um pouco e decidiu que os pedaços daquela matéria da qual seriam feitos os seres humanos e demais seres de sua criação deveriam ser restituídos à lama, e designou Iku para realizar esta missão. É assim que Iku Morte é um orixá que não tem assentamento, está sempre em volta do mundo realizando a sua missão, para que a lama restituída permita e se contente com a retirada de novos pedaços. Como se diz entre nós, "vai-se para dar vez a outros".

Essa matéria original é que denominamos de ipori, que garante a dinâmica do ciclo vital morte-renascimento; axéxe, origem das origens, princípio dos princípios que se renovam. Aspectos do mundo mineral, vegetal e animal compõem a matéria original, e todos esses aspectos da natureza estão presentes no ser humano.

Quando o orixá retira aspectos da natureza para Oxalá, ele imprime, por assim dizer, sua força, que será preponderante na criação de determinado ser humano, seu aspecto de natureza presente predominante. Aquele será seu eleda, o seu orixá. Os orixás são princípios que caracterizam as forças da 
natureza; água, terra, vento, fogo, floresta, vegetação, árvores, movimento, morte, saúde, doença, plantio, colheita, caça, transformação de minério em metal, a vida em expansão comunitária, etc...

O ori e ori-inu, a cabeça e seu interior onde está estabelecido o odu, o destino da pessoa, é elemento de profunda significação na constituição do ser humano. Ajala e 16 odu mais Osetuwa são quem fazem as cabeças e constituem a multiplicidade dos destinos. Energia, sinergia, ação e movimento, circulação das substâncias que movem o ser humano e seu destino são princípios dinamizados por Exu Bara. Oba + ara, o rei do corpo, responsável pelas vias internas que proporcionam dinamismo a existência concreta e individual. Muitos outros conceitos referentes aos orixás e aos seres humanos foram divulgados de forma acadêmica por diversos trabalhos que constituem uma bibliografia atualizada, como por exemplo, os de Juana E. dos Santos e Deoscoredes M. dos Santos, Alapini. Contentemo-nos com esta pequena ilustração da condição de nossas comunidades-terreiro nagô que na memória de suas narrativas míticas de uma sabedoria milenar realizam complexas e profundas elaborações do existir através de riquíssima liturgia, constituída por incontáveis combinações simbólicas e por uma estética que caracterizam as formas de comunicação rituais comunitária.

Certa vez, vi um vídeo documentário francês sobre a entrega dos presentes à Yemanjá, no dia 2 de fevereiro, na colônia de pescadores do Rio Vermelho. $\mathrm{O}$ repórter insistia em saber de várias pessoas presentes como era a "sereia”. Quase todos respondiam que Yemanjá é uma força que governa as águas ou expressão de maternidade, poder feminino, uma grande mãe... Depois, ele foi entrevistar a Iyalorixá que preparava os preceitos do presente principal fazendo a mesma pergunta, já um tanto chateada pela insistência do francês, a senhora respondeu: "Olha, meu filho, quem viu a sereia não voltou pra dizer como ela é."

Assim é que os orixás são princípios abstratos, mistério da existência, são princípios ativos que regem a natureza e constituem a dinâmica entre esse mundo, o aiyê e o orun, o além. As pessoas cujo destino e ancestralidade são constituídas como responsáveis pela circulação do axé, da força que dinamiza a vida para que esse mundo não se acabe através da tradição litúrgica, são capazes, através de rituais de manifestação dos orixás, de concretizar sua presença num aqui e agora de acordo com o espaço e a temporalização do contexto sagrado.

Uma linguagem estética simbólica, onde matéria, forma, textura, cor, gestos, som, movimento, cheiro, sabor expressam uma complexa taxinomia cosmogônica, promove os vínculos comunitários dos fiéis reunidos compartilhando paixão, emoção e elaborações de mundo, vivências que aplacam a angústia dos mistérios do existir pela religião.

Assim sendo, esse longo prólogo tem por fim abordar em dois ou três parágrafos a polêmica das esculturas do Dique do Tororó. Rapidinho, tais esculturas nada têm a ver com orixá, como a mídia se refere. São objetos de 


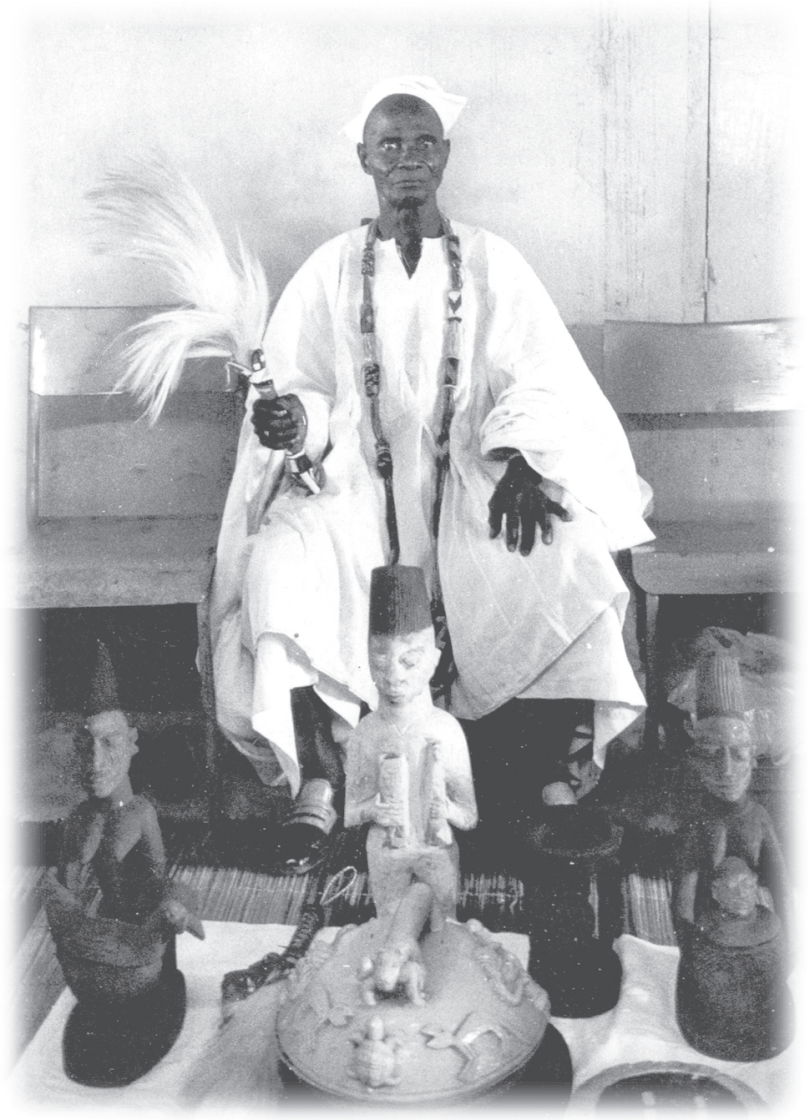

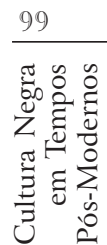

6 - Sacerdote de Ifá de alta hierarquia em Oyó - foto Marco Kalisch, 1981 
latão procurando retratar, através das artes plásticas, as sacerdotisas do culto aos orixá. Não há nessa constituição escultural quase nada do contexto e da complexidade simbólica ritual dos elementos estéticos característicos que constituem a representação de cada determinado orixá.

A forma de aproximação da artesania articulada com a divulgação da mídia acabam por realizar, na verdade, um recalque à riqueza erudita, cultural e espiritual da tradição africano-brasileira, realizando uma simplificação banalizante. Por outro lado, orixás são forças da natureza e, como tal, são já de muitos e muitos anos as tradições de realizarem as oferendas às forças que regem as águas no Dique de Tororó por determinadas comunidades. O protestantismo sempre se colocou como ponta de lança das conquistas continentais coloniais, neo-coloniais e imperialistas do império-britânico e do bloco hegemônico, do poder anglo-saxão nos EUA. A ânsia catequética missionária sempre aprovou os genocídios contra os "pecadores", isto é, os que têm outras religióes e outros territórios e suas riquezas.. Para acabar com a religião dos orixá, só acabando com toda natureza e todos os seres humanos juntos. Combater as esculturas que comentamos como se orixá fossem, chega a ser patético, quanto mais estando nós na Bahia... Como dissemos, para nós todo ser humano tem o seu orixá. É famoso o episódio ocorrido na década de 30, quando o então delegado Pedrito Gordo invadiu a comunidade do babalorixá Procópio do Ogunjá e acabou na ocasião manifestando o seu orixá... Tempos de perseguição, quando também o genro da afamada Tia Ciata, o Germano, fundou o bloco $O$ macaco é outro. Não seria hoje em dia "O diabo é outro"? 


\section{O LUGAR DO POLÍTICO NA TRADIÇÃO NAGÔ}

De acordo com as histórias da tradição, no início do mundo era o nada. Foi o ato criador de Olorum que proporcionou a existência, primeiramente na presença do ar e depois nas águas e na terra.

Neste tempo, ele enviou as Iya-mi Agba, as mães ancestrais na forma de grandes pássaros. Eram sete pássaros. Três pousaram na árvore do bem e três na árvore do mal; o sétimo voa de uma à outra árvore. Assim se caracterizam a força e o poder das mães ancestrais, representadas coletivamente por Oduduwa. Elas tanto podem propiciar o bem-estar, a plenitude da existência, como o mal-estar e a interrupção do desenvolvimento do destino. Elas proporcionam prodigalidade e fertilidade aos que as respeitam e cultuam, e castigam aqueles que as desrespeitam.

Outra história conta que certa feita, Obatalá, tendo realizado todos os preceitos indicados pelo Babalawô, insistiu em conhecer os segredos de Oduduwa que ela ocultava em seu quintal. Um dia, ele a seduziu oferecendolhe omi-eró - água que apazigua, e a carne de igbin - caracóis. Deliciada e apaziguada, ela permitiu a Obatalá conhecer Egungun, matéria ancestral. Após essa ocasião, Oduduwa surpreendeu-se vendo Obatalá conduzindo com sua vara de atori, Egungun pelas ruas da cidade. Inicialmente, ficou irritada, porém após algum tempo sentiu-se gratificada de ver Egungun vestido com seus panos, caminhando e falando. Ela então o abençoou, enviando seu pássaro com o axé eleye para acompanhá-lo. Assim, Egungun ficou depositário desses poderes e Obarixá com poder de manejá-lo e conduzi-lo. ${ }^{2}$

Oduduwa e Orixá-nla estão ritualmente representando no igba-du, a cabaça da existência. A metade de cima representa Orixá-nla, poder genitor masculino, a metade de baixo, Oduduwa, poder genitor feminino. No interior da cabaça, matérias massas genitoras, ou um passarinho, terceiro elemento, resultante; a cabaça simboliza o ventre fecundado, resultado de complementação dos princípios masculinos e femininos. Entre as duas metades 
da cabaça, sucessão de triângulos desenhados, $2+1=3$, ancestralidade em contínua expansão, descendência ininterrupta.

Uma outra história conta-nos como Ogum, orixá primogênito, que abre os caminhos do desconhecido, símbolo de vanguarda, conhecedor da floresta, caçador e guerreiro, patrono da arte da metalurgia que engendra civilização, enfrentou os poderes das mulheres comandadas por Iyansã, orixá do vento e do relâmpago, e como os homens então tornaram-se senhores absolutos do culto aos Egungum.

Finalmente, outra história conta-nos como Egungun, considerado filho de Xangô com Iyansã, roubou as roupas de Xangô, caracterizadas pelas tiras de pano, abala, que representam ancestralidade e descendência. As referências a esta série de passagens resumidas dos mitos da tradição nagô, baseadas no livro Os Nagô e a Morte, de Juana E. dos Santos, visam o entendimento do exercício e lugar político do culto dos ancestres e dos orixá, forças cósmicas que regem o universo na sociedade nagô.

$\mathrm{O}$ ato criador de Olorum diferenciou a idéia de caos da idéia do existir. $\mathrm{O}$ existir se caracteriza pela diferença entre forças em constante movimento formando um ciclo vital. Essas forças se caracterizam pela multiplicidade e necessária complementação.

A expressão da existência é o resultado da complementação harmoniosa dos múltiplos e diferentes aspectos gerados do existir.

Assim como a natureza é regida por forças que se manifestam nos distintos elementos que a compõem, a sociedade também se constitui dessas forças, pois elas regem o cosmo incluindo as sociedades. Portanto, a sociedade é um aspecto da ordem da existência que se caracteriza pelo sentido de complementação e harmonia das diferenças que a destingue do nada, do não existir, do caos.

A origem das cidades se liga diretamente à história dos seus fundadores, que a estabelecem com as regras que firmaram a continuidade da tradição direcionada no sentido de harmonizar as diferenças. Por sua vez, o exercício da aceitação da diferença, da alteridade, permite a instauração das identidades e da linguagem que caracterizam os lugares e poderes sociais.

A hierarquização dos poderes que deve visar sua necessária complementação, constitui as identidades e institui valores sociais e políticos.

Os fundamentos da ordem social portanto são transcendentes. Ela adquire sentido a partir de seu passado original que se realiza no presente e se projeta no futuro sucessivamente.

A identidade de um grupo social, de uma cidade, de um reino ou de um império, se constitui transcendendo seu presente, retornando seu sentido a partir de seu passado projetando-o no futuro.

A linguagem pela qual uma sociedade se constitui e comunica seu próprio existir se refere a seu momento original que the empresta sentido ou destino. 
Este destino está dado na linguagem através dos relatos que se referem a sua fundação, quando surgiu da instalação de um ou mais Orixá, de um ou mais ancestrais, em determinado território com determinado povo. Cada cidade possui seu orixá patrono e seus ancestrais fundadores.

A política do sagrado se caracteriza por re-ligar e presentificar o sentido originário que empresta identificação, linguagem e comunicação à sociedade.

O poder político se realiza em meio à tensão dialética entre o mundo sagrado das forças que regem o universo, de um lado, e a sociedade, de outro. Os orixá e ancestrais, de um lado, e os seres humanos, de outro, em relação transcendente-imanente e vice-versa.

É a tensão entre os ara-orum, os habitantes do orum, o além, e os araaiyê, os habitantes desse mundo, que através dos ritos empresta sentido à ordem do exercício do poder.

O exercício do poder transcendente-imanente é emanado, portanto, em última instância, dos orixá e ancestrais que dele participam num aqui e agora.

Essa característica transcendental da ordem política é que instaura a hierarquia assentada nos valores da antigüidade ritual-institucional e na sua descendência.

Quanto mais um indivíduo, uma família, uma sociedade cumpra o seu odu, o seu destino ou seu ciclo de existência, plenamente, sem que sejam proporcionados males que afetem e o interrompam através da morte prematura, é sinal que foram sábios no lidar com as forças invisíveis que regem o existir.

O oba, rei, é aquele que com sua corte, sacerdotes, e súditos consegue a harmonia social concretizando o sentido benéfico das forças que regem o universo, atendendo as prescrições litúrgicas, re-alimentando as forças dos orixá e ancestrais através das oferendas determinadas e dos festivais anuais.

Em Oyó, capital política do império nagô, o posto de Obaxorum é tão importante quanto o de Alaafin, o rei. O Obaxorum é o rei que trata das coisas do reino a partir do sentido emergente do orum. Ele é considerado ara oba o jé, integrante do corpo real. Ele compartilha o poder com o Alaafin.

Neste ponto, ancianidade e ancestralidade ritual-institucional revelam sua razão de poder e hierarquia. Os critérios de identificações estabeleceram os iniciados mais velhos como os mais capazes de re-ligar e atualizar o sentido das forças do orum ao aiyê, por deterem a sabedoria acumulada através da experiência ritualizada de introjeção de axé, que lhes permite aproximar-se e lidar com o perigoso mundo das forças que regem os ciclos do existir.

O poder se concretiza e se realiza através do exercício e da experiência em saber controlar as forças da existência genérica e abstrata, transcendente e imanente, portanto, em tensão dialética com a existência concreta individualizada, visando propiciar a plenitude do destino da sociedade. 
Na cultura nagô, a aspiração de todos está representada no conceito oracular de alafia, que significa plenitude de realizações das potencialidades do destino.

Para tanto, é preciso saber lidar com forças ambivalentes criativas e destrutivas, pois é o mesmo vento que afaga e afasta o calor, o que causa as catástrofe dos vendavais; é a mesma água que mata a sede e fecunda os campos, que causa a inundação; a mesma mão que dá é a que tira, etc.

Assegurar que os lugares sociais e as hierarquias sejam preenchidos por aqueles que detenham o saber e o poder de controlar essas forças, propiciando seus aspectos benéficos conforme a situação contextual, proporcionando o bem-estar e a expansão social, é preocupação de toda a sociedade na aceitação de seus líderes, que se ajustam ao poder dos Orixá e dos ancestres.

Os mitos a que nos referimos, vários referendam e mencionam o poder dos Egungun, os ancestres masculinos.

Eles detêm o poder do axé eleye, delegado por Oduduwa, e também o poder dos orixá da direita, constituído por Obatalá, assim como o poder dos orixá filhos, Ogum e Xangô.

Eles, portanto, têm o poder da descendência e da expansão e organização da existência. Daí a proeminência do culto aos egungun em Oyó, capital política do império. Oyó, que tem Xangô como orixá patrono, que rege as forças capazes de promover a vida social, a harmonia, a expansão e o bemestar de seus filhos.

Os mais velhos são aqueles que estão mais próximos dos ancestres, sua transcendência está assegurada pela continuidade de suas linhagens, tanto no que se refere a sua ascendência, seu passado, como em sua descendência, seus filhos, que lhes assegurarão sua existência em outro plano após a morte, e sua palavra como Egum terá força de lei.

Mas, se de um lado o poder político ancora-se na transcendentalidade do reino, de outro ele é exercido no aiyê e, portanto, exige ações específicas neste plano do existir. É nesse plano que atuam o Alaafim, seus ministros, seus conselhos, chefes militares e seu corpo administrativo. Suas ações decorrem desta tensão dialética transcendente-imanente característica das relações entre o orum e o aiyê.

Para tanto, o Alaafin deverá receber a anuência dos ancestres do palácio, que representam os ancestres das linhagens fundadoras do império nagô-yoruba, que têm como sacerdote máximo o Alapini, ipekun ojé. Das formalidades que caracterizam a coroação do Alafim: este receberá a coroa de folhas de Akoko, como símbolo de outorga dos poderes da ancestrabilidade do império.

É neste ponto que se situam as observações de Wande Abimbola, presidente da Conferência Mundial de Tradição dos Orixá e Cultura, conclamando o povo desta tradição à maior participação política.

A política do sagrado desdobra-se e completa-se em atuações no aiyê, na constante tensão dialética com as forças emergentes do orum. 


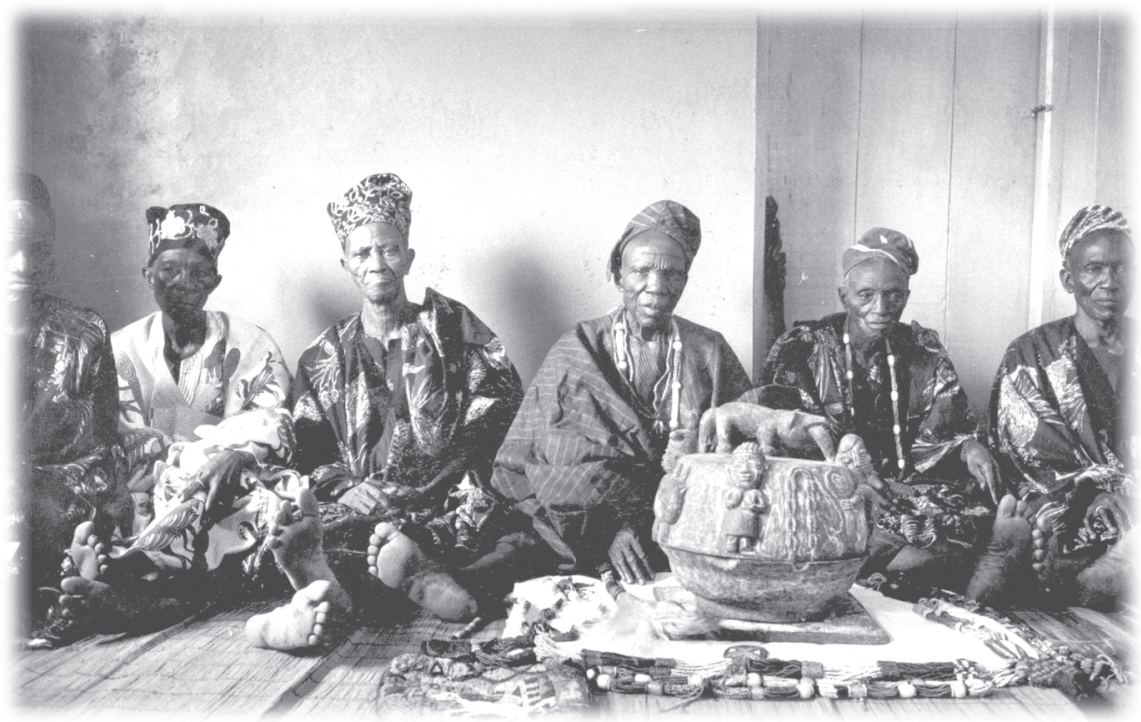

7 - Conselho de Anciãos em Oyó, Nigéria, durante a recepção à I ${ }^{a}$ Conferência Mundial da Tradição dos Orixá e Cultura Ilé Ifé - foto Marco Kalisch, 1981 
Na concretização desta política, forma-se no Brasil o INTECAB, Instituto Nacional da Tradição e Cultura Afro-brasileira, que reúne as diferentes correntes da tradição que compõem o legado dos ancestres africanos no Brasil e que têm na sua coordenação o Alapini, Sr. Deoscoredes M. dos Santos, da família Asipa, uma das sete linhagens fundadoras do reino de Ketu e originária de Oyó.

O INTECAB é uma instituição que procura implantar no Brasil, de um lado, o intercâmbio com as instituições componentes da continuidade da tradição, na África e nas Américas, e de outro, incentivar esse intercâmbio entre diversos, a comunalidade diversa africano-brasileira, fortalecendo a luta pela legitimação e expressão dos valores civilizatórios. Através da estratégia caracterizada pelo lema União na Diversidade, composto por um conselho religioso, e um conselho consultivo, ele mantém a dinâmica do poder que aproxima as dimensões transcendentais e imanentes da política da tradição.

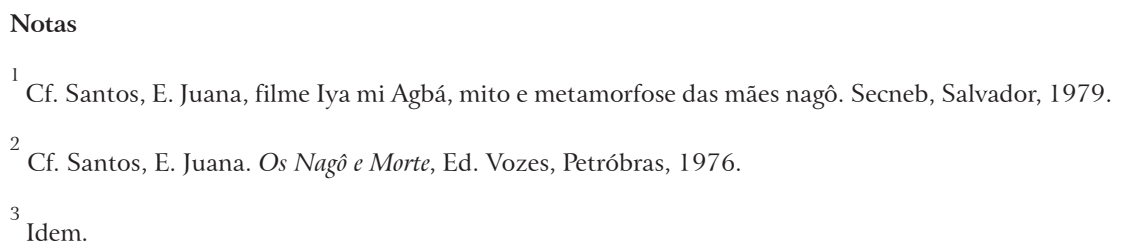




\section{ANCESTRALIDADE E SIMBOLOGIA: 25 anos do Ilê Asipá}
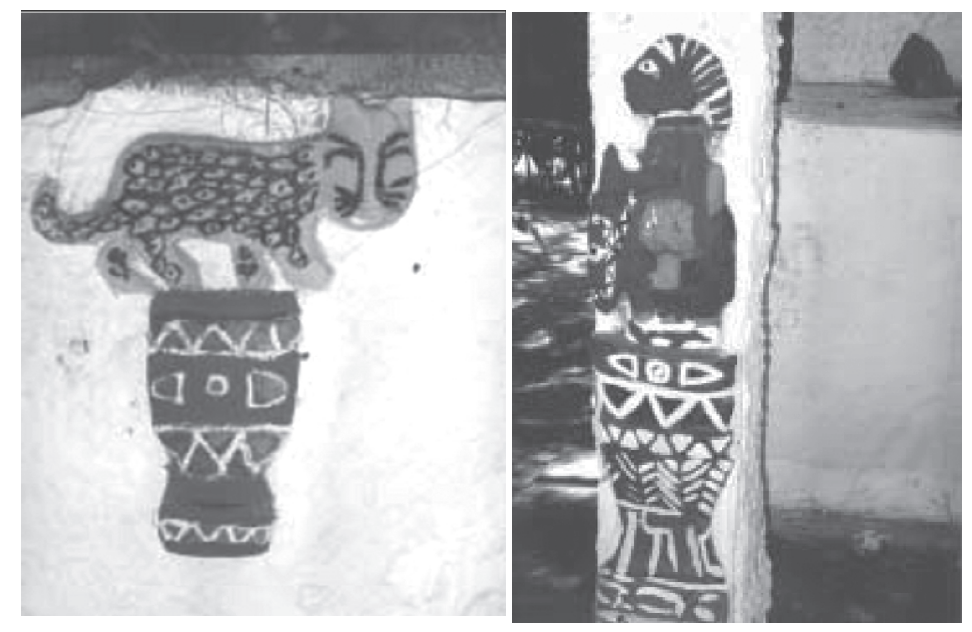

Patrimônio artístico religioso do Ilê Asipá.

Escultura e Foto: Marco Aurélio Luz

Nas comemorações dos 25 anos do Ilê Asipá, visitava a exposição de fotografias que registravam os inícios da comunidade acompanhado de um ore $m i$, um amigo de Ilê Ifé, a cidade de origem do povo nagô-yorubá.

Observando as fotos das esculturas em alto relevo que compõem as colunas da varanda do ilê ibo igbale comentamos a do leopardo sobre o pilão, ekun ati odo e do cavaleiro, elexin. Eu falava que quando fiz as esculturas me inspirei num oriki de Xangô que fala no leopardo,na pantera,como poder de 
ataque,e que também caracteriza o cavaleiro,desbravador,guerreiro e fundador de cidades,lembrando a famosa cavalaria de Oyó,cidade central do antigo império nagô,e origem do culto aos baba egun, os ancestrais.

Foi também quando me referi ao Festival de Epa da região de Ekiti que tomei conhecimento recentemente através do capítulo "Os Escultores do Nordeste" de John Pemberton III do livro Yorubá, Nove Séculos de Arte e Pensamento Africano.

Por coincidência esse meu amigo me disse que sua esposa era originária de Ekiti.

Foi então, que resolvi homenageá-los começando minha comunicação no âmbito do Seminário Ancestralidade Existencial que compunha as comemorações dos 25 anos do Ilê Asipá, me referindo ao Festival Epa.

Linguagem e simbologia sustentam as formas de comunicação que alimentam os modos de vinculação humana que caracterizam a diversidade das sociabilidades riqueza da humanidade.

Pemberton III conta que o povo reunido com autoridades religiosas, aguardam a passagem dos ancestrais, que através das esculturas simbólicas que portam sobre a cabeça, narram aspectos fundamentais dos princípios que regem a trajetória da humanidade e da comunalidade nagô-yorubá.

Primeiramente aparece Oloko, o senhor do campo, da savana, trazendo a escultura do leopardo abatendo o antílope, representação do predador, o caçador, no alvorecer da humanidade é um dos seus principais aspectos desde os seus inícios enquanto espécie.

Depois surge na área de danças dramáticas o ancestre que traz a escultura do Ologun, o guerreiro, Elexin, o cavaleiro com lança, o caçador, o desbravador.

Depois das evoluções desses ancestres, saudando as autoridades religiosas, e dançando envolvidos pelo povo, abre-se espaço para o aparecimento de $A o$, ancestre que traz a representação dos poderes do Babalawo, o consultor do oráculo, pai dos mistérios do fluxo dos destinos e do Onixegun ou Babalosaiyn, o sacerdote conhecedor das folhas e das poções e preparos religiosos e medicinais. "São poderes essenciais para estabelecer e manter o bem estar pessoal e social do guerreiro, bem como físico e a arte militar do guerreiro"( $I$ )

O Festival atinge um clímax com a chegada de Eyelaxé a representação simbólica da escultura que magnifica e qualifica a mãe que possui o poder.Também conhecida como Iyá Ibeji mãe dos gêmeos,significando fertilidade feminina.

Finalmente surge o Orangun, título de um dos reis da região, sua esculturasímbolo é do rei cavaleiro rodeado de tudo que é gente das comunidades aldeãs ou das cidades, caçadores, guerreiros, ferreiros, músicos que estão todos sob um pálio protetor, ou imenso guarda-sol.

Podemos entender que através da representação simbólica dos princípios do processo contínuo da sociabilidade humana acontece num aqui e agora a 
articulação da temporalidade litúrgica a seqüência da participação de cada ancestral com a temporalidade da narrativa que fala por assim dizer, de cada aspecto ontológico da historicidade, isto é, do devir da humanidade.

Mestre Didi, Asipá, Alapini, sacerdote supremo do culto aos Baba-egun, relatou o conto do lenhador, que fala de um morador da margem de um rio, que um dia resolveu visitar um babalawo para saber de seu destino pessoal.

Foi-lhe revelado que ele viajaria por muitos lugares, conheceria muitas coisas e depois que voltaria para aquele seu lugar. E de fato assim aconteceu,voltando ao seu lugar de origem onde terminou o seu destino.

A tradição religiosa nagô, especificamente o culto de baba-egun, os ancestres masculinos originários de Oyó e Ketú no Brasil visam através da liturgia a propiciar uma vida melhor possível aos seus integrantes, que tenham o desenvolvimento completo de seus destinos superando os obstáculos e adversidades inerentes ao existir.

Desde quando viemos a esse mundo sabemos que um dia voltaremos. A vida e a morte são uma coisa só,okan naa mi...diz a filosofia nagô.Iku, Morte foi o orixá que recolheu a proto-matéria que ajudaria Oxalá a fazer os seres humanos.Como a lama,ipori,ficou vertendo água chorando,quando Iku arrancou o pedaço para levar a Oxalá, ele ordenou que lhe caberia a função de depois de certo tempo levar de volta realizando a restituição.

Para cada ser humano Oxalá fazia também uma árvore(2), e no Ilê Asipá determinadas árvores são cultuadas usando um paramento de oja funfun, um pano branco em volta do tronco.

Convém fazermos uma referência a relação significativa do culto aos ancestrais com as árvores,especialmente ao igi Akoko que é cultuada pela tradição nagô yorubá e tem presença simbólica efetiva na liturgia e nos rituais.(3)

Oxalá,foi também quem deu movimento e ação ao Egungun, depois que conseguiu ter acesso ao segredo guardado no quintal de Oduduwa. (4)

O calendário do Ilê Asipá começa no início de cada ano com um ebó odun, a oferenda do ano para que o destino dos participantes da comunidade flua sem muitas atribulações.

Em seguida em torno do dia de Reis, ocorre o Festival litúrgico de Baba Olukotun, olori egun, senhor da direita um dos ancestrais masculino mais antigo, o cabeça dos Egungun representa o alvorecer, os primórdios da humanidade os primeiros ancestres.

É a humanidade que cabe garantir a liturgia da tradição que renova e dinamiza axé para que esse mundo não se acabe.

Ancestralidade, ou melhor, o culto a ancestralidade está assentado em reforçar o axé necessário à continuidade ininterrupta dos ciclos vitais. Os ancestres e ancestrais são homenageados por se dedicarem a manutenção,preservação e expansão da comunidade dedicada a tradição ou 
melhor a tradição religiosa, as relações entre esse mundo e o além,capacidade de mobilização do axé.

Em junho a homenagem se refere ao Baba Alapalá, que representa na historicidade da espécie humana o período de conquista do fogo, a domesticação do fogo para diversos fins, mas para nós é importante frisar o início da sociabilidade, os humanos reunidos em volta da fogueira para pensar e refletir sobre os mistérios da existência, o estar nesse mundo, se aproximar através do re-ligare, da religião do ritual em volta do fogo. Esses antigos ancestres africanos,vieram para o Brasil através da famíliaTheodoro Pimentel,nas pessoas de Marcos o Velho e seu filho Marcos.

Em julho, em data referente à memória de Mãe Senhora, Iyalorixá e Iyá Nassô, da família Asipá, se homenageiam os ancestrais da família Asipá, dentre eles Baba Ebiteiye e Baba Ojunilê.

A linhagem Asipá é uma das sete famílias fundadoras de Ketu, de fundamental importância para a implantação da tradição do culto aos orixá no Brasil.

Em novembro homenageiam-se os ancestrais e o corpo dos ojé, sacerdotes dedicados ao culto Baba Egun.

Convém ressaltar que o Ilê Asipá dá continuidade ao culto a Idako, ancestre do povo Tapa ou Nupe, herança do sacerdote mais alto denominado Zabá, título do Sr. Miguel Sant'Anna, que também foi ojé e possuía outros postos da tradição nagô.

A ancestralidade elaborada como princípios ontológicos da humanidade é sedimentada por relações institucionais que interagem sinergicamente, isto é, as da tradição dos ancestres com as da tradição dos orixá, diferentes, mas complementares.

Não há atuação litúrgica sem que não sejam invocados e homenageados os ancestres e ancestrais.

Mas passando para outra instituição e que integra o patrimônio cultural religioso do Ilê Asipá, veremos como é elaborada a presença histórica dos africanos no Brasil.

Trata-se do afoxé Pae Burocô fundado por Mestre Didi na década de 1930 no tempo da Iyalorixá Oba Biyi. Não vamos nos deter aqui em explanações sobre o afoxé,apenas nos deter numa das seqüências de cantigas que elaboram o processo histórico da presença da comunalidade afro-brasileira.

Iniciamos o hino ao som dos clarins e desenvolvendo depois ao som da percussão do ritmo ijexá:

Buroko oba IboBuroko rei da floresta sagrada

Buroko oba aiyê

Buroko rei deste mundo

Buroko oba orun Buroko rei do além

Buroko oba omon Buroko rei dos filhos

Onilê ooo

O senhor da casa 
A origem está expressa no cântico, todo em língua yorubá. Na seqüência os cânticos revelam através da língua e da linguagem a presença num contexto histórico adverso no Brasil.

\author{
Oh viva Dieu viva Dieu \\ Viva Dieu pai Olorun \\ Oh viva Dieu viva Dieu \\ Viva Dieu Sinhô di Bófim
}

Diz o Mestre:

Soldado de minha comanda

Toca calcanhá pra Santo Antônio de Bara

Frente pro Sinhô de Bófim

Qui terá é nosso

Jiri bum bum

Coro: Qui terá é nosso

Viva Dieu Viva Dieu

O afoxé evolui, até que o vigia dá o sinal:

Pae Burokô soldado evém

Jakuriman, Jakuriman,

Coro: Pae Burokô soldado evém

Jakuriman, Jakuriman,

Num contexto hostil e adverso, o grupo expressa suas estratégias de luta e preservação:

Coro: Pae Burokô toca bando

Qui eu vai cumpanhando

Mestre: Entre em beco sai em beco

Coro: Entre em beco sai em beco

Mestre: Quando eu sobi ni ladera

Coro: Eu cai eu diruba

Com a liderança do Pai Burokô,o afoxé supera as dificuldades e os obstáculos.

Depois de passada a perseguição e luta o descanso e a liberdade...

Tabara, Tabara, tim tim Jaka

Coro: Eku joko

E finalizamos com o cântico que anuncia a continuidade da tradição que garante o bem estar nesse mundo, vivendo com alegria e satisfação no âmbito da comunalidade originária: 
O canero berô

Bereré

O menino choro

Bereré

Cala a boca neguinho

Cala a boca menino

Bereré

Como dizia Mãe Senhora Asipá, metade se fala, metade se cala...

Mestre Didi Asipá, Alapini, é fundador de outras instituições de cultura e interação das tradições afro-brasileiras. Com ele a participação de muitos integrantes da comunidade Ilê Asipá.Mas isso já é uma outra história...

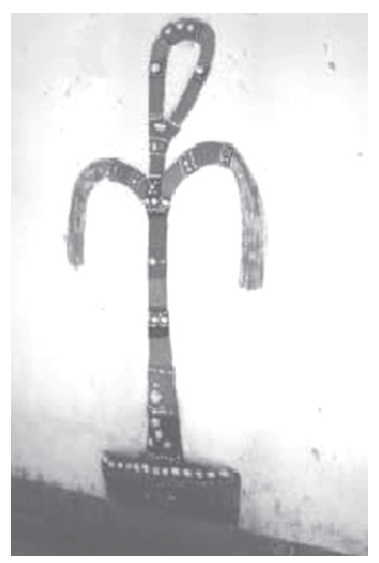

Iwin igi

O espírito da árvore

Escultura de Mestre Didi no Ilê Axipá.

Foto de Marco Aurélio Luz 


\section{A ARTE DE MESTRE DIDI}

Mestre Didi, Alapini, sacerdote supremo do culto aos ancestrais Egungun, através de sua atuação como artista obtém este ano um merecido reconhecimento, convidado pela $23^{\mathrm{a}}$ Bienal de São Paulo, realizará uma amostra de 33 peças em sala especial ao lado de outras salas especiais do circuito das artes plásticas internacionais como Picasso, Goya, Andy Wahrol, Paul Klee, Edward Munch, Tomie Ohtake e Louise de Bourgeois.

Nada mais significativo, neste momento, que homenagear um escultor de fama internacional, que ocupa no mundo das artes plásticas um lugar de originalidade impar.

Nascido de importante família originária de Ketú, os Axipá, que no Brasil se destacaram como fundadores e continuadores das tradições sagradas nagô, Mestre Didi é hoje um dos mais antigos e respeitados sacerdotes, possuindo dentre seus diversos títulos o de Assogba, supremo sacerdote do culto ao orixá Obaluaiyê e Alapini, supremo sacerdote do culto aos Egungun, ancestrais masculinos.

Imerso num mundo tradicional negro-africano transplantado para o Brasil, e tendo tido oportunidade de estar varias vezes na África, onde vivenciou experiências históricas, como o reencontro com a família Axipá, o recebimento de significativo título dado a ele pelo Alaaketú, rei de Ketú, além de ter realizado em Oyó a confirmação do seu título de Balé Xangô, Mestre Didi se situa visceralmente no âmbito da episteme estética da arte tradicional africana.

Essa arte é admirada em todo o mundo, a partir mesmo das referências à esplendorosa civilização do Egito antigo, marco da humanidade, e preenche os museus da Europa e EUA, influenciando sobremaneira a arte de diversos povos nos tempos modernos e contemporâneos.

A arte dos povos nagô ou ioruba, e de seus vizinhos, e por assim dizer parentes, como os edo do reino de Benin, constituem-se em amostra de excelência da estética tradicional africana espalhada pelo mundo. 
Essa estética se constitui principalmente de duas dimensões. Uma está ligada às homenagens rituais aos reis, chefes e heróis, na formação do culto aos ancestrais, principalmente a arte que é elaborada para os palácios.

A outra, visa a magnificar o sagrado no que se refere ao culto às forças da natureza, os orixás e, está presente na arte elaborada para os templos e liturgias.

Tanto uma quanto outra se constitui como arte de representação de símbolos, visa a expressar conceitos que fazem parte de uma complexa visão de mundo.

Neste sentido, a arte escultórica e pictórica tradicional emerge dos altares, dos paramentos rituais, e também de elementos que compõem a arquitetura dos palácios e templos.

Um terreiro tradicional no Brasil congrega e condensa aspectos essenciais dos reinos e impérios; seus orixás e seus ancestrais.

Na condição de Assogba, Mestre Didi começou a fazer os emblemas sagrados dos orixá do panteão da Terra.

O Xaxará, emblema de Obaluaiyê, e o ibiri, emblema de Nanã, são feitos de matérias, possuem formas e cores que exprimem determinados conceitos referentes a aspectos da visão de mundo que esses orixás representam.

As taliscas ou nervuras das folhas de palmeira enfeixadas em forma ventral são representações coletivas dos espíritos ancestrais. As superfícies em couro coloridas, caracterizam com sua cor, a qualidade de axé, princípio e força controlada pelo orixá. Búzios enfileirados representam ancestralidade, continuidade de linhagens, ciclo vital. As contas representam partículas desprendidas da qualidade de força do orixá, exprimem a dinâmica entre o aiyê - este mundo, e o orun - o além.

A forma de vassoura, demonstra que com o xaxará Obaluaiyê controla as doenças, ora afastando, limpando, recolhendo.

Rei dos espíritos do mundo, Oba-olu-aiyê, é sentinela e guardião dos valores da tradição. A lança, exin, é outro de seus emblemas.

$\mathrm{O}$ ibiri, feito de taliscas de palmeira enfeixadas em forma ventral, caracteriza o princípio feminino regido pelo orixá Nanã. Ventre, terra restituída de matéria ancestral, constitui o ciclo vital.

Princípio de multiplicidade, variedade da vida, dos destinos, dinâmica do ciclo vital, arco-íris que emerge e retorna à terra, Oxumaré é outro orixá panteão da terra, irmão de Obaluaiyê e filho de Nanã. Ele é representado pelos emblemas de duas cobras.

As recriações de Mestre Didi, constituídas com os elementos desta arte sacra, demonstram a complexidade dos valores e significado da constelação dos orixás do panteão da terra.

A geometria vazada das suas esculturas atualiza e representa a dinâmica do vazio e do pleno, do visível e do invisível, integrando em sua expressão a dialética entre o orun, o além e o aiyê, o mundo concreto individualizado. 


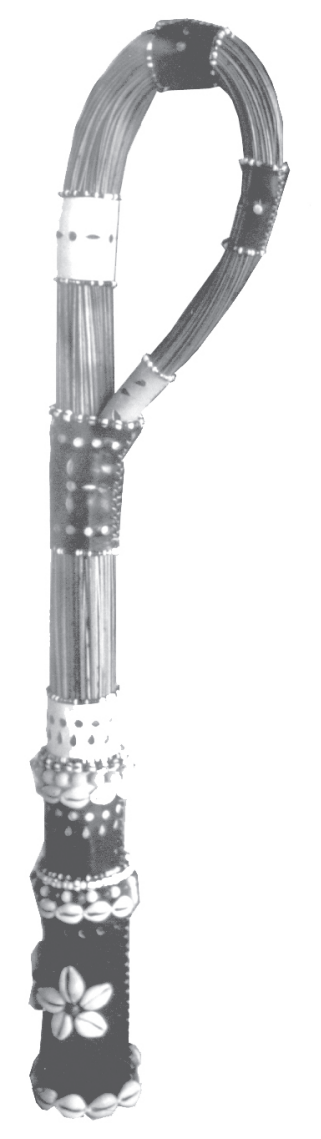

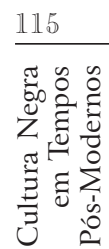

8 - O Ibiri e o Xaxará, esculturas paramentos feitos pelo Asogba, Mestre Didi, Alapini - foto de M. A. Luz, Salvador, 1983 
Na galeria Prova do Artista, o ibiri, o xaxará e ejo meji, duas cobras, abrem espacialmente uma amostra.

As demais esculturas expressam relações e conceitos estéticos do panteão dos orixás da terra, como Opa Ossain ati ejo meji, cetro de Ossãiyn e duas cobras, igi iwin, o espírito da árvore, ejo l'orun e Dan, as cobras místicas, opa exin meta, cetro com três lanças, dentre outras.

Destilando a seiva nobre da tradição, recriando esculturas para o espaço das galerias, Mestre Didi expande sua cultura, com toda autenticidade e genialidade que o faz um artista contemporâneo que sem dúvida enriquece com sua originalidade o acervo estético do mundo das artes e enche de orgulho a identidade africano-baiana. 


\section{OPÔ BABA N'LAWA}

Na véspera do dia de entrega das oferendas da colônia de pescadores do Rio Vermelho a Yemanjá, num local bem próximo, num outeiro sobre o mar, descortinando todo o horizonte de luzes e cores que a vista alcança e se perde em direção ao continente africano, foi inaugurado o Opô Baba N'Lawa.

No momento solene, com a presença das autoridades governamentais, de autoridades da tradição e do povo em geral, Mestre Didi e o prefeito de Salvador, acompanhados das respectivas senhoras, descerraram a placa comemorativa da inauguração.

O Opô Baba N'Lawa é um cetro em homenagem a nossa ancestralidade africano-brasileira, um marco histórico, a maneira negro-africana, como o Opa Oraniyan dos yorubá, ou os famosos obeliscos egípcios.

Embora uma das características estruturantes da tradição africana seja o culto aos ancestrais, cuja origem se perde na noite dos tempos, não deixa de ser significativo que a sociedade oficial, através da prefeitura, outorgue ao Mestre Didi, um sacerdote-artista, Alapini e Assogbá, supremo sacerdote do culto aos ancestrais masculinos, os Baba Egun, e também sacerdote supremo dos orixá do panteão da terra, Obaluaiyê, a responsabilidade da elaboração do cetro que homenageia a ancestralidade africana responsável pelo legado civilizatório que marca profundamente nossa identidade.

No Brasil, o culto aos ancestres africanos possui diversas matrizes litúrgicas e rituais adaptadas a nossa terra e que constituem um dos pilares da tradição, que vai das congadas aos cultos de Baba Egun, passando pela genuinidade dos Caboclos, Preto-Velhos, e dos Inkices, Bakuros, Voduns, etc., constituindo a cultura predominante que alimenta a alma e a espiritualidade brasileira.

Os cultos aos ancestres ora se referem a linhagens fundadoras de reinos e cidades e mantenedoras da continuidade dos valores civilizatórios, transmitindo seu precioso legado as novas gerações, baluartes na defesa e 
manutenção de sua identidade própria, ora se referem as origens da própria humanidade, transcendendo a temporalidade histórica para elaborar o mistério da gênese nos momentos mais profundos da liturgia.

Na primeira referência, a temporalidade histórica tem como ponto inicial as origens africanas e sua ancoragem nas Américas e passa pelo período recente de lutas de libertação e resistências à escravidão européia, enfim, contra o sistema colonial mercantil escravista, para alcançar os dias atuais, em que a tradição preservada, alimenta a comunalidade e a sociabilidade africanobrasileira, que se desdobra, perpassando de forma diversa a totalidade do tecido social componente da identidade nacional.

Localizado de forma a ter como fundo a linha do horizonte infinito do oceano em direção a África, ambas situações estão contempladas na simbologia da historicidade expressa no Opô Baba N'Lawa . É que a nossa ancestralidade é homenageada não só pela riquíssima herança cultural trazida pelos africanos para as Américas, mas também porque a origem da humanidade, do homo sapiens tal qual somos, está na própria África.

Emergindo do solo, a lança projetada em direção à atmosfera, celebra a continuidade da tradição que por sua vez garante a continuidade da humanidade. Sentinela dos valores da tradição garante a circulação do axé, da força vital, os ancestres são depositários e guardiões da sabedoria capaz de proporcionar a expansão do existir.

Os ancestres, portanto, são a fonte de onde flui a continuidade da tradição. Na tradição nagô são sempre invocados e homenageados em todos os ritos precedendo ou iniciando a liturgia que mobiliza as relações entre o aiyê - esse mundo, e o orun - o além.

Assim como na cosmogonia nagô, os orixá, forças da natureza que governam o universo são classificados por princípios femininos e masculinos, também os ancestres têm ritualmente essa qualificação.

No Opô Baba N'Lawa, os dois princípios e poderes estão contemplados. Além da lança de forma fálica e com a representação em bronze de sua textura de feixe de taliscas de mariwo caracterizando o poder da ancestralidade masculina, o interior da terra ventre fecundado, de onde emerge o Opô caracteriza o poder da ancestralidade feminina. Os dois passarinhos em ambos os lados da peça por sua vez representam o poder de progenitura, resultante do movimento e da interação entre os princípios.

$\mathrm{Na}$ forma original das recriações de Mestre Didi, a textura de suas esculturas segue os elementos simbólicos dos orixá do panteão da Terra, especificamente o Xaxará e o Ibiri. Assim, as taliscas de palmeira mariwo, os búzios, couro, contas e cores, fazem parte das obras recriadas. Na presente peça, foi constituída uma réplica em bronze, material capaz de melhor resistir as intempéries da exposição em praça pública. Todavia, convém sublinhar que o bronze retorna a arcaica técnica de cera perdida, característica do 


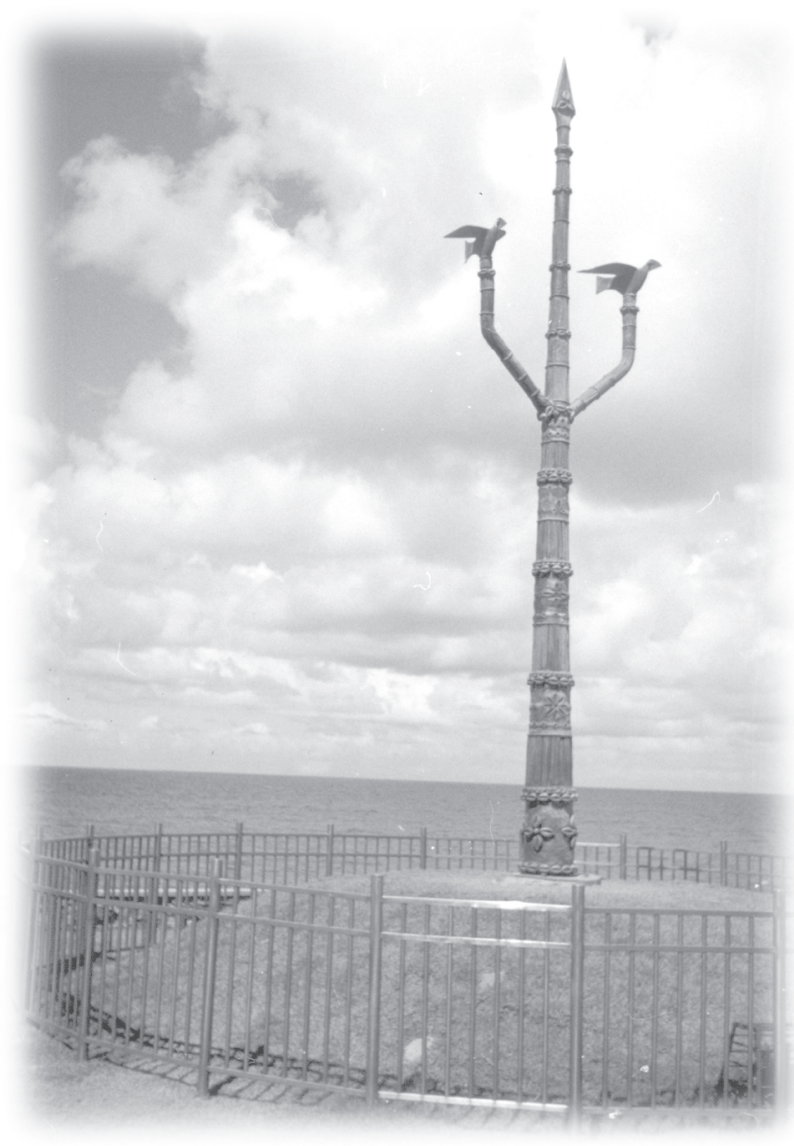

9 - Opô Baba N'lawa escultura réplica em bronze, homenagem a ancestralidade africanobrasileira de Mestre Didi, Alapini, na praia da Paciência, Rio Vermelho, Salvador, BA - foto M. A. Luz, 2002 
acervo das famosas esculturas do patrimônio cultural de Ilê Ifé, a cidade sagrada dos Yorubá.

Em 1974, participando do $I^{o}$ Seminário sobre o Nordeste: Preservação do Patrimônio Histórico e Artístico, realizado em Salvador, Juana Elbein dos Santos realizou a comunicação Conscientização do Patrimônio Negro-Brasileiro, chamando a atenção para o fato de que a ausência de quaisquer políticas de preservação, se constituía num desdobramento do recalcamento de projeções coloniais escravistas. Alertava para pontos cruciais que, pouco a pouco, no decorrer das últimas décadas, alguns foram devidamente contemplados como:

\& o inventário de peças museáveis da arte negro-brasileira;

œ o inventário e as homenagens aos quilombos, do passado e do presente;

« desobstrução da fachada do Ilê Iyá-Nassô, prejudicada pela presença ostensiva de um posto de gasolina;

« exposição em local adequado e/ou devolução de material sacro confiscado pela polícia e exibido de forma deplorável em museus da academia de polícia ou afins.

Enfim, vários outros aspectos significativos de nosso patrimônio cultural foram apontados, e que agora, com o Opô Baba N'Lawa, se vai assumindo também uma nova postura do poder público, reconhecendo a diversidade sócio-cultural como característica componente da riqueza de nossa identidade própria.

A escolha da homenagem à ancestralidade não poderia estar melhor representada do que por uma escultura de Mestre Didi. Ele, que além de ser considerado um dos mais insignes representantes da arte contemporânea, que recria uma linguagem estética a partir de sua profunda experiência de sacerdoteartista, é descendente de uma das mais tradicionais linhagens componentes do antigo império nagô-yorubá, a família Asipá; referência de ancoragem e continuidade ininterrupta do processo civilizatório negro-africano.

A importância do cetro, obelisco em homenagem a ancestralidade é de um efeito estético análogo ao oriki, poema de louvação à memória da Iyá Oba Tosi, uma das fundadoras da tradição nagô na Bahia e as mães ancestrais, invocado em determinadas ações litúrgicas. Diz o poema em um de seus versos: 
A de o!

Kosi mi fara e awa re!

Kosi mi fara e awa re!

Awa kasa i fara e la i be si bo.

Idan toba fara a ng a lo lo dan.

Kosi mi fara e awa re!

Kosi mi fara alejo.

Ara wara kosi mi fara!
Chegamos e estamos aqui!

Nada há no mundo que possa contra mim, aqui estamos!

Nada há no mundo que possa contra mim, aqui estamos!

Nunca deixaremos de ofertar e rogar em nossos altares por nossa gente.

Podem usar o poder que quiserem.

Nada há no mundo que nos atinja, aqui estamos!

Nada há que possa contra mim, nem mesmo os estrangeiros.

Todos unidos num mesmo corpo, nada há no mundo que possa contra mim!

$\mathrm{Na}$ pequena enseada do Rio Vermelho barcos e canoas ancoradas compõem o cenário das relações da humanidade com o reino de Olokun e Iemanjá. Uma canoa com pescadores singra o mar em direção a praia, onde no amanhã serão embarcadas as oferendas aos orixá, para que o mundo não se acabe...

\section{Notas}

${ }^{1}$ Cf. Santos, Juana E. Conscientização do Patrimônio Negro-Brasileiro, in SÁRÉPEGBÉ. Salvador: Sociedade de Estudos da Cultura Negra no Brasil - SECNEB, p.21-23, 1995.

${ }^{2} \mathrm{San}$

Santos, Deoscoredes M. Homenagem a Asipá Oba Tosi ati Iya Mi Agba (mimeografado, Salvador, 1983) in LUZ, Narcimária do Patrocínio. ABEBE a Criação de Novos valores na Educação. Salvador: Edições SECNEB, 2000, p.137-139. 

Durante a constituição da República, a política de embranquecimento desde o Império, de aumentar a proporção da população branca e seus valores, ganhou novas reformulações estratégicas, sobretudo na criação do apartheid ideológico, diferenciando o Brasil das políticas separatistas dos EUA e da África do Sul.

A imposição da ordem do Estado Moderno, iluminista, positivista, uno, totalizante e burocrático, e do progresso, capitalista industrialista, exigia uma renovação ideológica que justificasse o genocídio dos povos que se atrevessem a viver com os valores de um mundo diferente.

Alimentando a Razão de Estado com uma ideologia da discriminação ajustada as teorias evolucionistas europocêntricas que sedimentaram a República, sobressaíram dentre outras, a produção "psi” de Nina Rodrigues e Arthur Ramos.

Provavelmente percebendo o valor da religião na cultura africanobrasileira, procuraram desqualifica-la. O primeiro, igualou com sua arrogância "científica", o momento da liturgia de manifestação do orixá da sacerdotisa, ao sintoma da histeria, palavra constituída da derivação de hister, útero e que se atribuía à mulher num contexto de discriminação machista. O segundo, foi buscar nos relatos de um tal coronel Ellis do exército colonial britânico uma história de Iemanjá, que ninguém conhecia por aqui, mas que se encaixava no paradigma edípico de sua psicanálise para declarar a cultura negra "atrasada" e "neurotisada". Quanto a política de discriminação se robusteceu desde então!!. Daí para o estigma e o estereótipo da "Nega Maluca", e do "Nego Feiticeiro" foi menos de um passo; constituindo o imaginário que justificasse as repressões policiais aos terreiros e outras instituições da comunalidade africano-brasileira. 
Todavia, agora, na "contemporaneidade globalizante", novas formas de comunicação, mais sutis e encantadoras procuram chegar aos mesmos objetivos, isto é, tentar descaracterizar o poder e o saber da comunalidade afro-brasileira.

Acompanhando o show em que a TV transmite o desfile das escolas de samba do Rio de Janeiro, fiquei curioso com as reações e o debate em torno da tal "madrinha da bateria". Não bastasse o poder dos carnavalescos advindos da participação das Secretarias de Estado do Turismo, com a TV se reforça a idéia, já há muito denunciada por Cartola, dentre outros, que os desfiles das escolas de samba se transformaram numa "ópera ambulante".

Observamos então já há algumas décadas, que o desfile abriga uma luta entre a pulsão comunal da tradição original de um lado, e de outro a ideologia do espetáculo do mass mídia.

A TV tenta transformar e absorver do território cultural da comunicação direta da tradição setores expressivos dos valores que sustentam a identidade própria das escolas de samba. Assim foram se modificando, a comissão de frente, composta pelos mais antigos, e transformada em um grupo dramático de apoio a opera, os passistas substituídos por alas coreográficas, o ritmo se acelerou ajustado ao timing da TV, ganharam espaço, carros alegóricos monumentais, de altura celestiais, com os destaques, agora de artistas da mídia da fama virtual ou de gente de dinheiro, e até na ala dos compositores o carnavalesco invade, misturando sambas enredos ao seu bel prazer. Tudo isso ocorre em meio a uma sujeição voluntária, como diria Maffesoli, ou sujeição premiada, aquela que pode ser ilustrada pela lição contida na música Conceição, interpretada por Cauby Peixoto,como queiram...

Todavia, devo me ater a refletir sobre a tal madrinha da bateria, que a cada desfile ganha mais espaço na mídia, na tentativa de deslocar pra esse território o paradigma dos concursos de Miss, e também um deslocamento da vinheta da comunicação virtual da logo marca Globeleza.

A imagem adequada da TV oscila pendularmente entre uma personagem erótica que alimenta o voyeurismo virtual desde o show de Sargentelli, até o ideal de corpo de modelo ultimamente na moda se destacando nas passarelas com sua aparência virginal inapetente e seus passos marciais, fazendo par com corpos masculinos construídos nas academias da gimnástica, que por sua vez ocupam os carros alegóricos.

Mas eis que neste carnaval, dentre as beldades da competição aparece Preta Gil, com toda sua volúpia roliça, madrinha da bateria da Mangueira, é sim, a Estação Primeira...

Como autêntica herdeira das atuações tropicalistas, ela causou sensação, e bagunçou o "coro dos contentes".

Das muitas cartas dos leitores que li, um declarava que ela deveria mudar de lugar, indo pra ala das Baianas... 
Ora meu caro missivista, a ala das baianas não é o lugar... Ela sim abriga corpos e mentes que se destacaram por participar da instituição, lutando por ela ao longo de sua história. A ala das Baianas homenageia as que sustentaram e sustentam a continuidade dos valores de civilização da saga africana no Brasil criando a cultura do povo brasileiro em geral.

Nesse contexto o corpo feminino está envolto em outros valores. Primeiramente os que estão expressos na cosmogonia da religião dos orixá, os princípios e poderes das A Iya Agba nossas venerandas mães. O mistério e o poder do corpo feminino de gerar e gestar filhos e alimentos que asseguram a continuidade das famílias e linhagens, que expandem a comunidade e reforça a ancestralidade e seus cultos, tanto masculino, os Baba Egun, quanto feminino, o Gelede, dentre outros, valoração do ventre fecundado, continuidade ininterrupta da vida.

Da sensualidade voluptuosa do desejo à maternidade, da devoção a senioridade à ancestralidade, todos esses aspectos do mistério da gênese estão representados no contexto das instituições da comunalidade religiosa. .

Nesse universo a dança dramática ocupa um lugar fundamental, é ela o elemento capaz, conjuntamente com a música percussiva da orquestra ritual dos alabes, de proporcionar a comunicação do sagrado, a comunidade reunida celebrando a circulação de axé, reforçando os vínculos indissolúveis entre o aiye e o orun entre esse mundo e o além.

A linguagem e os valores da tradição incluem e se desdobram em instituições, como o samba de roda e o afoxé, dentre muitas outras. Eles compõem o que se convencionou chamar de mundo do samba.

Esse mundo inclui uma enorme variedade de gêneros, desde o samba de roda até as escolas de samba; todos animando à vida, dando vazão a pulsão comunal, como diria Maffesoli, o prazer de estar junto, compartilhando elaborações de vida sensações, emoções e alegria.

No tempo em que ainda as brasileiras, e como sempre as africanas, traziam seus filhos amarrados aos panos nas costas assentados nas pujantes cadeiras, protegidos de tudo e de todos, acalentados pelo balanço do andar gracioso e ritmado, percorrendo as roças e mercados, nos inícios do século passado, ocorreram levas de emigração de nordestinos, sobretudo, da Bahia para o Rio de Janeiro.

Esses se localizaram na região portuária, ocupando as localidades da Saúde, Gamboa, Pedra do Sal, Cidade Nova, envolvendo a famosa Praça Onze, que conjuntamente com outras áreas limítrofes formaram o que Heitor dos Prazeres denominou, mais tarde de Mini-Africa.

Foi nesse contexto histórico que se destacou Hilária Batista de Almeida, Iya Kekere do terreiro de João Alaba. Ciata de Oxun, Tia Ciata como ficou popularmente conhecida, foi homenageada neste carnaval pelo Salgueiro e pela Beija-Flor, pela legenda que se constitui na musica brasileira e no mundo 
do samba, enfrentando com dignidade a repressão e os fortes preconceitos da época. Mas, assim como Tia Ciata centenas de milhares de baianas possibilitaram a expansão do contínuo civilizatório africano para além da Bahia. Essa memória se constitui na essência original da simbologia da Ala das Baianas nos desfiles das escolas de samba.

Nesse ponto não podemos deixar de sublinhar o erro de procurarem transformar essa ala, que possui essa simbologia própria e fundamental, em simples suporte de figurinos e adereços de apoio aos enredos para satisfazer a criatividade duvidosa e grotesca de alguns carnavalescos sob o foco desmesurado da mídia.

Sendo eu Oju Oba, não poderia deixar de destacar as visitas prolongadas ao Rio de Janeiro, na primeira metade do século passado, de gente importante como a legendária Eugênia Anna dos Santos Iyalorixa Oba Biyi, fundadora do Ile Axé Opo Afonja, conjuntamente com Rodolpho Martins de Andrade, Bamboche Obitiko e Joaquim Vieira, Oba Sãiya, pai da tia Cantulina Pacheco, Oba Aira, que mais tarde seria a Iyalorixá do Ile Axé Opo Afonja do Rio de Janeiro...

Por fim, mais recentemente,em maio de 1965, Mãe Senhora, Maria Bebiana do Espírito Santo, Iyalorixá Oxun Muiwa, por iniciativa do líder religioso Tata Tancredo da Silva Pinto, recebeu no Maracanã, homenagem de seus filhos e admiradores cariocas, sendo escolhida a Mãe Preta do Brasil. Nessa ocasião declarou:

"É com grande alegria que recebo esta homenagem, e, em nome de todos os orixás, abençôo meus filhos brancos e negros de todo o Brasil, e faço votos para que no dia das Mães de 1965 tenhamos todos paz e bem-estar neste Brasil que é a melhor terra do mundo."

Era também sob a liderança do Tata Tancredo que se realizava o encontro de centenas de terreiros em homenagem aos ancestrais, conhecidos como Preto Velho numa enorme Praça em Campo Grande, onde tem uma estátua da imagem de Mãe Senhora. Foi lá que certa vez ouvi também um ponto cantado que diz:

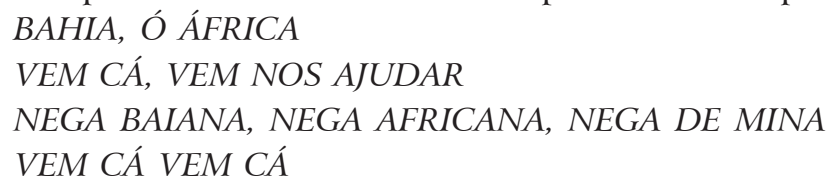

São tantas as baianas que sustentaram e sustentam o fluxo de continuidade civilizatória africana no Brasil, que por ocasião de mais um aniversário da cidade de Salvador, só temos que agradecer penhoradamente,

\section{OSEUN PUPO}

1-Cf. Filme Iyami Agba, de Juana E. dos Santos, SECNEB, Embrafilme, 1979.

2-Cf. Santos M. Deoscoredes, História de um Terreiro Nagô, ed. Carthago e Fortes, 1994,SP,p.31. 
O discurso social quotidiano apresenta momentos altamente significativos para a compreensão da sociedade que vivemos.

Para nós que nos dedicamos a procura desses momentos, verdadeiros sintomas sociais, como cientistas não nos escapa a leitura do tão anunciado video-clip de Michael Jackson pela televisão. Nesta leitura, a narrativa do clip possui dois momentos de tensão distintos mas interligados.

O primeiro é quando, no início, a criança branca de classe média se revolta contra a repressão do silêncio e da inércia representada pelo pai na poltrona em frente ao aparelho de TV, caracterizando a ideologia do conforto do american way of life e que, mandando o pai para outros espaços através da explosão do som, abre caminho para o transcurso de seqüências em contextos onde fluem imagens de um mundo de movimento e beleza - música, dança, vestimentas, pintura em corpos coloridos.

Toda essa dimensão estética dos corpos em movimento apontam para a diversidade humana com suas outras formas de comunicação que estão sempre censuradas ou deformadas na TV, um dos principais aparatos do sistema do Estado unidimensional e totalizante da modernidade.

O clip aponta para uma enorme variedade do ser que margeia majoritariamente a unidimensão, a univocidade dos valores, a monotonia dos conteúdos televisivos. Mais que isso, a monótona pedagogia da postura inerte exigida dos telespectadores pela televisão, que estão controlados pelo panotismo sedutor desta máquina de Narciso, como se refere Muniz Sodré.

Mas devemos acrescentar que a exclusão racista do outro na TV, passa pela ideologia do conforto que exige a criação da identidade de um sujeito consumidor, posto ser sobretudo um veículo de estímulos ao consumo.

\footnotetext{
* Artigo publicado no Caderno Cultural do Jornal A Tarde, 1991.
} 
Portanto, estão fora outros segmentos sócio-culturais, outras tradições civilizatórias que não estão centradas neste valor nem naquela forma de comunicação.

E é por elas, exatamente, que Michael Jackson flui na narrativa metafórica do video-clip, com o canto e o encanto de sua música e dança, aludindo a uma identificação e aliança com aqueles que exprimem, deste modo, numa comunicação direta, participante, dinâmica, suas mensagens, criando momentos estéticos capazes de promover o compartilhar das mesmas paixões e emoções, fortalecendo, desta forma, os vínculos comunitários.

Todavia, numa dimensão de mundo planetária, o contexto da diversidade humana está cada vez mais permeável ao intercâmbio e quem sabe um dia a um verdadeiro ecumenismo.

Nesta dimensão, o clip, através das trucagens de transformação dos rostos, aponta que a diversidade sócio-cultural não se limita aos significantes da morfologia ou da cor. A significação é dada sempre contextualmente, independente da relação que se possa estabelecer entre "raça" e cultura.

É por isso que transmutando seu próprio rosto e o tom de sua pele, Michael Jackson, através de sua linguagem negra, pode num determinado contexto, como na segunda parte do clip, "des-transformar-se" em pantera negra, ou melhor, sê-la e não sê-la.

O colonialismo e o imperialismo geraram a aproximação de contextos sócio-culturais diversos, e o transitar por entre eles, se situar nos intertícios do Estado positivista, totalizante, prometéico, é uma característica própria das populações e das comunidades que o margeiam.

Por outro lado, a subversão que caminha mascarada como um retorno do reprimido, caracteriza a narrativa do clip, onde o recalcamento racista da sociedade industrial é driblada e a mensagem se politiza no sentido original do radical pólis, isto é, múltiplos, variados, aglutinados pelo compartilhar da fé dionisíaca.

Explicitemos melhor a especificidade deste recalque e as razões dos disfarces para superá-lo.

$\mathrm{Na}$ era do gramofone a indústria cultural procurou capitalizar o que o público americano já opinara, que a música negra era vibrante, fascinante, e valiosa, muito além que a do próprio "mundo branco".

Mas, já na época das big bands, que filtravam e diluíam a música original da era do swing, os brancos se apropriam da arte musical negra mas recalcam seus autores.

Como ressalta Muggiati no seu livro Rock, o Grito e o Mito:

O sucesso de Benny Goodman se deveu à sua interpretação de King Porter Stomp, composição do negro Jelly Roll Morton, arranjada por outro negro, Fletcher Henderson. Tommy Dorsey é outro branco que se 
torna famoso da noite para o dia com um arranjo (Marie) copiado nota por nota de uma orquestra original negra, a dos Sunset Royal Serenaders de Doc Wheeler. E Glen Miller, oferecendo um salário pouco maior, rouba o arranjador negro Ly Oliver da fabulosa orquestra de Jimmie Linceford e torna-se mundialmente famoso à custa de seus arranjos. Todos eles - Benny Goodman, Tommy Dorsey, Glen Miller, Harry James - ficaram milionários copiando a música de artistas negros que só com muita dificuldade conseguem se manter na profissão ...

Para ainda ilustrarmos esses mecanismos de racalcamento e exploração basta lembrarmos de $\mathrm{Al} \mathrm{Johnson,} \mathrm{que} \mathrm{se} \mathrm{pintava} \mathrm{de} \mathrm{preto} \mathrm{e} \mathrm{mais} \mathrm{recentemente}$ Elvys Presley, que ocuparam a cena da industria cultural no campo musical e do espetáculo encerrando no silêncio os verdadeiros responsáveis por inúmeras formas de expressão artística que fascinam o público.

Não precisaríamos ir muito longe para entendermos as razões do disfarce de Michael Jackson.

No teatro mundi que é o futebol brasileiro, onde estão representadas e dramatizadas as tensões de nossa sociedade diversa e pluri-cultural, em 1920, o jogador Carlos Alberto para jogar no team do Fluminense do Rio de Janeiro, teve de se encharcar de pó de arroz a cada partida ... mas isso é também assunto para outras conversas.

O fato é que com esse ambíguo disfarce de Michael Jackson, a música negra norte-americana atinge um clímax de evidência jamais alcançado na indústria cultural.

E, contrariando o que afirmava um dos maiores músicos do jazz, Fredie Keppard, em 1912, com certa razão, a de que "o gramofone traria a morte do Jazz...", a raiz jazzistica se expande, englobando a dança, ampliando o espaço da forma de comunicação negra como está bem caracterizado pela onda do rap nos Estados Unidos e Europa.

Neste sentido, Michael Jackson sabe que realiza uma subversão no paradigma pedagógico da modernidade, nos valores estéticos da sociedade industrial, da ideologia do conforto e de seus fetiches.

Na seqüência narrativa do video-clip, entrando e saindo no corpo da pantera negra, símbolo de conotações caras ao movimento negro norte americano e divulgado mundo afora, só dançando como ele sabe, sem canto, realiza uma audaciosa coreografia destruindo os vidros do automóvel, do neon do Hotel Real da Armada, as vidraças do escritório da burocracia, fetiches da modernidade...

Fetiches, porque por representação metonímica, a parte pelo todo, através da divulgação da propaganda do Estado, encobrem o preço que a humanidade vem pagando pela modernidade, ou seja, os genocídios na América e na África, e na Ásia, o tráfico-escravagista, a canalização de recursos da indústria armamentista que hoje pode destruir sessenta vezes o mundo (?!) etc. 
Também, é como se esses vidros, vidraças e neon, formassem a casca de uma redoma que tenta enclausurar num só reflexo a projeção das imagens narcísicas procurando assim cercear a liberação das identidades variadas para além do contexto consumista-produtivista.

Além disso, a coreografia reafirma a genitalidade como força desrepressiva e criativa, abalando a censura característica dos prazeres pervertidos e deslocados da sexualidade reprimida da ideologia do conforto que envolve a classe média puritana norte americana.

Um dos símbolos dessa ideologia na atualidade, o "anti-herói" dos desenhos animados, Simpson, que vive as aventuras do quotidiano banal da existência nas instituições do consumo da classe média, não pode suportar que seu filho se encante com a sedução estética de Michael Jackson e desliga a televisão. Com esta seqüência, um recurso de metalinguagem, se dá o encerramento do video-clip, Black or White.

Assim, como Simpson, a televisão brasileira censurou a segunda parte na representação do clip. E no dia seguinte, para justificar-se, o Jornal da Noite, reportou-se ao clip com o apresentador referindo-se a um tal de Michael Johnson... combinação de Michael Jackson com Al Johnson (?!), dizendo que o clip causou polêmica nos Estados Unidos, e numa constituição metonímica de imagem, censurou tudo o que a narrativa trazia para apenas mostrar a coreografia, da genitália exposta afrontosamente.

Mas não adiantaram as explicações, a indústria cultural e, portanto, a televisão mordeu a isca dionisíaca da pós-modernidade, implodindo seu monopólio da fala, ela mesma anunciando mensagens de novos tempos, black and white, verdadeiramente ecumênicos e plurais.

\footnotetext{
Notas

${ }^{1}$ Muggiati, Roberto-Rock, O Grito e o Mito, a música pop como forma de comunicação e contra-cultura, Vozes, 1973, p.30 s.s.
} 


\section{MUTANTE EGÍPCIO Remember the Time, TV de Cor*}

Em artigo anterior publicado na "A Tarde Cultural", realizamos algumas reflexões sobre o clip de Michael Jackson, Black or White. Naquela ocasião, chamamos a atenção sobre duas partes da narrativa: a primeira, que se referia à diversidade humana, compreendendo as diferenças culturais e suas formas de comunicação; a segunda, que indicava que para se perceber essa multiplicidade de alteridades, era preciso quebrar as vidraças da redoma do paradigma do Estado ou sistema social da modernidade uno, unívoco e unidimensional, positivista, consumista e totalizante.

Essa segunda parte, uma ousada coreografia, foi posteriormente censurada pela TV.

Mas depois do quebra-quebra, não surge a anomia, a desordem ou o caos. Ao contrário, emerge com o clip Remember the time, o novo com a projeção dionisíaca da temporalidade pós-moderna, apontando para valores antiquíssimos das civilizações humanas, alimentando a força imaginal constituinte de novas utopias.

Uma das características da pós-modernidade é a emergência da afirmação da diversidade humana e da pluralidade cultural, mesmo que essa emergência venha acompanhada de reações como ocorre com alguns movimentos intransigentes como, por exemplo, na França e na Alemanha.

Portanto, esse novo, já foi aludido pelo clip Black or White nas imagens das crianças brancas que metaforicamente pontuam a nova esperança de um possível verdadeiro ecumenismo.

Em Remember the time, também elas estão lá, ao lado de Michael Jackson, assistindo as filmagens.

\footnotetext{
* Artigo publicado no Caderno Cultural do Jornal A Tarde, 1992.
} 
O novo é, portanto, a crença num mundo mutante, mas, ao mesmo tempo, de valores imperecíveis como pode se decodificar da presença do gato e o ouro, matiz dourado que transluz na encenação e abre a narrativa do clip.

O ouro, neste contexto, não é símbolo de riqueza entesourada traduzido em contabilidades monetárias, mas, por ser metal nobre, imperecível, tange a simbolização da dimensão inexplicável da eternidade do existir, gema de ouro.

Luminiscências douradas marcam essa coreografia que conta uma estória do Egito faraônico. Um faraó que querendo agradar sua esposa entediada, oferece-lhe a apresentação de algumas atrações espetaculares para que se divirta. Todavia, ele perde o controle quando um personagem misterioso e sedutor desperta nela a paixão. Com seus soldados, ele persegue o personagem que, acuado, some no invisível.

Poderíamos perguntar, conforme se faz com as fábulas de Esopo, qual a moral da estória?

E responderíamos, primeiramente realçando o fato de todos os atorespersonagens serem negros. Isto porque durante anos de colonialismo, o Egito faraônico foi representado, de forma deformada, embranquecido..., especialmente há alguns anos atrás pela indústria do cinema de Hollywood.

Num tempo, que ainda se prolonga, em que as ideologias racistas e positivistas procuravam apresentar os povos não-brancos como inferiores através de sofisticadas teorias, o Egito faraônico, berço das civilizações, causava um impacto que precisava ser silenciado.

Entretanto, os movimentos de libertação do colonialismo e do imperialismo trouxeram em seu contexto intelectuais como Cheikh Anta Diop do Senegal, que dedicou-se, em seus trabalhos, resgatar a veracidade étnica negra do Egito faraônico, constituído no baixo Egito, e num tempo muito anterior, as presenças de povos semíticos e indo-europeus e cuja formação étnica era totalmente distinta da atual população mestiça árabe-mulçumana que caracteriza o país na atualidade.

Cabe acrescentar, que Diop e outros intelectuais provocaram significativa revisão das influências do Egito faraônico em diversos continentes, não só na África, na Ásia e na Europa, mas também na América, comprovando relações entre a civilização Egípcia e a dos Maia, Azteca e Inca, ocorridas há milênios.

Portanto, é nesse Egito negro faraônico resgatado que se desenvolve a dramatização da narrativa de Remember the Time.

Além disso, porém, a narrativa possui um significado transcendental.

É que diante das atrações espetaculares, a rainha não se comove nem com a destreza do malabarista, nem com o poder mágico do engolidor de fogo. Ela se encanta, porém, com o personagem, entidade que semeia grãos, some e reaparece com nova forma. Aquele que é capaz de abranger com sua ação os planos do visível é do invisível. O que tangencia o mistério da gênese e, portanto, da ancestralidade. 
Sabemos que em geral na África e nas Américas negras, os papéis sociais masculinos e femininos são diferenciados, todavia complementares. Enquanto os homens estão mais voltados para a organização social comunitária, as mulheres estão voltadas para gerir o equilíbrio e a harmonia cósmica, uma vez tendo o poder sagrado de lidar com as forças da natureza.

O poder feminino está ligado ao processo de gestação, a capacidade de transformação do corpo da mulher, promovendo o desenvolvimento de um novo ser e que a aproxima das representações dos mistérios do interior da terra. O mistério da sucessão de linhagens, o eterno ciclo de nascimento e morte, envolve o desejo desperto de um poder feminino representado na narrativa por um beijo do personagem etéreo na rainha, com as pirâmides, que guardam os sarcófagos faraônicos, no horizonte da janela.

Pirâmides que representam a força de uma civilização alicerçada no culto aos ancestrais veneráveis, corrente ininterrupta de vida e morte que garantem o estarmos hoje aqui e agora... Na África e nas Américas negra, o culto aos ancestrais tem a mesma pujança na constituição das alianças comunitárias.

Todavia, esse desejo e poder despertado na rainha preocupa o faraó, e como o lúdico não está separado do sagrado, segue-se na narrativa a perseguição, o esconde-esconde, até que o personagem misterioso é cercado pelos guardiães do palácio e então some num redemoinho de pó de ouro; estava aqui, não está mais, visível/invisível, estará sempre...

Esta elaboração de aspectos transcendentais da existência, como indicou Muniz Sodré no livro Samba, o Dono do Corpo, está representado na música negra pela síncopa, a presença da ausência, o vazio, a batida que falta; presente, ausente, presente num tempo mais forte.

Englobar dimensões múltiplas da existência, ou do existir, o visível e o invisível é característica da cultura negra, elaborações de conhecimentos envoltos numa dimensão estética. Odara, é um conceito nagô onde o útil e o belo constituem-se de forma única, bom e bonito é uma coisa só. Essa dimensão estética do saber recorre a diversos códigos complementares que apóiam e expressam a narrativa. Dança, canto, música, dramatização, vestuário, coreografia, cenário, etc., se unem na harmonia da linguagem negra, e é o que Michael Jackson realiza na TV.

Assim como o negro americano já fizera com os instrumentos brancos criando o jazz, inicia-se um processo de TV de cor, pós-moderna. 



\section{DO TRONCO AO TAMBOR DO OLODUM COM MICHAEL JACKSON}

A presença de Michael Jackson e Spike Lee entre nós para fazer um vídeo clip, They dont care about us, "Eles não cuidam de nós", com toda a reação de boa acolhida de um lado e de rejeição de outro, geram desde já, a nosso ver, através da mídia um outro vídeo-clip que agora iremos comentar.

Michael veio e passou como um furacão de genialidade deixando reis da liberalidade e da democracia republicana nús, tentando se cobrir com as curtas cobertas da mídia.

Quando comentamos, em outra ocasião, dois vídeo-clips de Michael Jackson, o Black or White e Renember the Time ${ }^{1}$, sublinhávamos que a percepção das imagens indicavam que para além da diversidade humana de caráter morfológico, existem especialmente as diversidades civilizatórias características da humanidade.

Mas para a aceitação dessas diversidades, é preciso ultrapassar o mundo encantado e mistificador da mídia, explodindo especialmente as limitações da televisão, "o monopólio da fala" , constituinte do espectador inerte e adormecido em sua poltrona pelas mensagens europocêntricas. É assim que se inicia e avança a narrativa de Black or White em que o personagem Michael Jackson chega ao ponto de sair dos estúdios vampirizadores e se transforma em pantera negra para depois assumir as características de um Zé Pilintra que dançando solo realiza uma coreografia em que destrói um carro, a cortina de fumaça da ideologia do conforto, os neon da publicidade sedutora, o Hotel Real da armada, pilares dos valores da sociedade dita moderna, produtivista, consumista-positivista.

Gestos enaltecendo a genitalidade dentro desses movimentos agressivos de liberação provocaram a censura desta parte do vídeo-clip, segundo alegaram os censuradores, isto é, o sistema da mídia, o que aliás foi previsto no próprio clip, quando papai Simpson desliga a TV em que o filho via o programa, é como encerra-se a narrativa. 
Mas a superação desses obstáculos ideológicos permite em Remember the Time resgatar no ocidente a imagem do Egito faraônico, berço da civilização humana como legado e herança da civilização negro-africana.

Por outro lado, as referências à genitalidade são recuperadas aqui mais explicitamente como fonte do despertar do desejo que permite a continuidade da vida. Na narrativa, a rainha que recupera o desejo proporcionará a continuidade ininterrupta da gênese, mistério do existir e princípio da ancestralidade, gravada no acervo monumental das pirâmides.

Mistério da gênese e desejo, marcado pela genitalidade, caminham de mãos dadas nas elaborações de mundo das civilizações negro-africanas.

Todavia, a expansão da humanidade referente aos "não brancos" vem sofrendo, por atuação dos "brancos", forte repressão da época colonial mercantil escravista até os nossos dias.

Quando o Brasil, o pais campeão em desrespeitar os direitos humanos conforme instituições que os defendem, é escolhido como referência para a composição de um video-clip que denuncia essa repressão, não é a toa e não é de hoje.

É considerado o segundo maior pais de população negra do mundo, e não sendo um pais africano, pode-se especular que o tráfico escravista e a escravidão ocorreram de forma mais intensa aqui. Foi o último país a abolir a escravidão, sistema de exploração comercial-financeira genocida da força de trabalho.

Também realizou um massivo genocídio de povos ameríndios, tanto na época colonial como na modernidade republicana, quando prolongou a política imperial de embranquecimento também reforçando a ocupação de territórios no sul e sudeste para vinda de imigrantes europeus e proibindo a vinda de africanos e inicialmente até mesmo de asiáticos.

Em 12 de outubro de 1908, no jornal O Estado de São Paulo, era transcrito texto de Herman Von Ihering em que agradecia ter sido eleito sóciohonorário do Instituto Histórico e Geográfico de São Paulo ao tempo que afirmava:

Os atuais índios do Estado de São Paulo não representam um elemento de trabalho e progresso. Como também nos outros Estados do Brasil, não se pode esperar trabalho sério e continuado dos índios civilizados, $e$ como os caigangs selvagens, são um empecilho para a colonização das regiöes do sertão que habitam, parece que não há outro meio, de que se possa lançar mão, senão o seu extermínio.

O massacre de Canudos, em 1897, também constitui-se em sintoma da índole perversa europocêntrica positivista da República no Brasil no seu alvorecer, convocando seu exército de armas e equipamentos modernos a chacinar cerca de 25.000 nordestinos, em um período de um ano e pouco de batalhas, e na destruição de um povoado constituído por uma grande maioria de mulheres e crianças. 
Atrás do convento de Santo Antônio, no centro da cidade do Rio de Janeiro, instalaram-se os sobreviventes imigrados de Canudos. O local chamouse morro da Favela.

Favela é o nome da planta que, quando nela se encosta, queima, que havia em profusão no morro do mesmo nome existente em Canudos, como descreveu Euclides da Cunha.

As Favelas se multiplicaram nas grandes cidades . A profecia de Antônio Conselheiro de alguma forma se realizava, com o exôdo rural, provocado pela concentração da propriedade e do avanço da automação tecnológica na produção, faz com que "o sertão vire praia e a praia vire sertão".

Em 1911, as intenções políticas republicanas ecoam na participação de João Baptista de Lacerda, representante brasileiro no I Congresso Universal das Raças, em Londres, onde vaticinava que em 100 anos não existiriam nem negros nem mestiços no Brasil “... expostos a todas as espécies de agentes de destruição, sem recursos suficientes para se manter."

$\mathrm{Na}$ república, instala-se e desdobra-se a política do abandono, num país rico, e no entanto o de maior concentração de renda do mundo.

Devemos então nos ofender quando tentam os governantes impedir a presença de Michael no morro D. Martha e que Spike Lee indague se aqui é uma "República de bananas?!", aquela em que uma oligarquia, apoiada desde fora por potências imperiais, detém o poder enquanto o povo vive à mingua... "They don't care about us."

Mas voltemos aos comentários das atuações em torno do vídeo-clip dizendo que um mega star negro para fazer alguma coisa por sua gente tem que driblar a ação vampiresca da mídia. Ação que morde e assopra, que quer tirar o sangue do astro explorando cultural e comercialmente o uso de sua imagem, mas que não admite os conteúdos de suas mensagens.

Foi assim que agiu a mídia, de um lado querendo os "furos" das notícias e de outro tentando anarquizar sua imagem, como, por exemplo, através do humor cáustico de seus artistas mercenários do Casseta e Planeta.

Mas Michael expôs sua mensagem nas imagens em que tira o cassetete da guarda, segurança da republica?!, e então pode dançar pelas ruas do Pelourinho e pelos becos do D. Martha ao som da percussão do Olodum.

A solidariedade e irmandade da comunidade africano-americana teve também seu momento solene.

No lugar onde esteve o Pelourinho, o tronco dos açoites do período escravista, foi ocupado agora pelo tambor do Olodum. Tambor, símbolo de continuidade do legado africano; de uma civilização onde sempre a música se combina com a dança, corpo em movimento, em gestos que exprimem conceitos, filosofia e maneiras de compreender os significados da vida.

Ele dançou e dramatizou, acompanhando e enaltecendo o tocador e o seu tambor no coração do Pelô. 
Superando e não ligando para os preconceitos da mídia e de autoridades da sociedade oficial, através da atuação propiciada pela honrosa visita de Michael Jackson, sopraram ventos da liberdade e da solidariedade afroamericana.

\section{Notas}

I Cf. Luz, Marco Aurélio. Cultura Negra em Tempos Pós-Modernos, edições SECNEB, Salvador, 1992.

Cf. Sodré Muniz. O Monopólio da Fala, ed. Vozes, Rio de Janeiro, 1977.

Cf. Santos, Sílvio Coelho dos. Índios e Brancos no Sul do Brasil, ed. Edeme, Florianópolis, 1973.

${ }^{4}$ Cf. Cunha, Euclides da. Os Sertões, ed. Francisco Alves, 32a. ed., Rio de Janeiro, 1984.

${ }^{5}$ Cf. Nascimento, Abdias do. O Genocídio do Negro Brasileiro, ed. Paz e Terra, Rio de Janeiro, 1978. 


\section{BURN BABY BURN O Fogo da Justiça em Los Angeles}

Quando as câmaras de TV mostraram um grupo de jovens negros arrancando do caminhão um branco qualquer para espancá-lo, de forma dramatizada e didática, poder-se-ia ler o que se estava lecionando: - ponhase no nosso lugar e veja como se sentem os que sofrem a prepotência do supremacismo étnico anglo-saxão na América; ou como diz o nosso ditado: pimenta nos olhos dos outros é refresco...

O julgamento de Los Angeles que absolveu os policiais brancos que foram flagrados espancando arbitrariamente um rapaz negro representa metaforicamente o que há de subjacente na estruturação imperial neocolonialista da modernidade; isto é, a luta encarniçada das etnias brancas para manter o poder de supremacia mundial. E elas constituem cerca de $6 \%$ da população do globo. Causaram duas grandes guerras mundiais e fabricam artefatos de guerra capazes de destruir completamente o planeta. Para tanto o desgaste de energia de exploração de força de trabalho, de genocídios causados por domínio de territórios ou conquista de mercados, de destruição e poluição da natureza se acentuam de forma catastrófica.

Esta supremacia, portanto, se apóia na tecnologia, ou, em última instância, na disposição de fabricar e utilizar armas cada vez mais aptas em destruir milhares sendo usadas apenas por alguns. Bastou um piloto com uma bomba atômica para derrotar o Japão na segunda guerra mundial.

Os Estados Unidos se constituíram no âmbito da vocação imperialcolonial anglo-saxônica. A chamada "conquista do oeste" na verdade foi "o caminho das índias" dos EUA.

De um lado, o oceano Atlântico possibilitando lançar o manto de ferro da supremacia imperialista sobre as Américas, de outro, o Pacífico, o caminho aberto para a Ásia. 
De início, a desterritorialização e genocídios dos povos Cheyennes, Comanches, Sioux, Arapahos, Apaches, etc. etc. A ocupação dessas terras; concorrendo para isso o tráfico escravagista, se caracterizou pelas fazendas de produção de algodão, criação de gado, e a corrida do ouro...

Submetidos à escravidão, povos africanos também desterritorializados, foram transferidos a duras penas para a exploração do trabalho forçado sob tortura nas Américas.

Desta tragédia histórica não ficaram de fora os mexicanos. Ali estava dentre outros territórios, a Califórnia, a ser anexada...

Por outro lado, a independência do Haiti, que culminou com a vitória dos quilombos chefiados por Dessalines sobre as tropas de Napoleão, em 1804, transformou o mundo moderno.

A partir daí, o tráfico escravagista, responsável indireto pela africanização das Américas, estava com os dias contados, e abriu passagem ao desenvolvimento do capital industrial e com ele as ideologias iluministas, positivistas, produtivistas, que alteraram os matizes do imperialismo, deslocando até mesmo, com o passar dos anos seu centro hegemônico de poder.

Com uma marinha de navios de vela tornada obsoleta pela construção dos navios de aço e vapor, a hegemonia imperial britânica passa para os anglo-saxões da América.

As ideologias imperialistas da modernidade se pronunciam por variadas cabeças como podemos observar nesta citação de Marx e Engels, judeu alemão e anglo-saxão respectivamente.

Temos testemunhado a conquista do México e a festejamos... é do interesse do seu próprio desenvolvimento ser, no futuro, colocado sob tutela dos Estados Unidos, que graças a conquista da Califórnia atinge a dominação de todo Oceano Pacífico... Será uma infelicidade que a maravilhosa Califórnia seja arrancada dos mexicanos preguiçosos, que não sabem o que fazer com ela?... Todas as nações, impotentes devem obedecendo às necessidades históricas, se juntar a um grande império... assim se permitindo a participação no desenvolvimento histórico...

Ideologias européias dos "tempos modernos" sublimavam as "conquistas"... Em nome do progresso e da história, povos eram "inexoravelmente" massacrados. A natureza, em sua bio-diversidade, impiedosamente destruída. A Califórnia hoje não é mais que um imenso campo de laranjas.

As diversidades humanas atacadas de todas as formas, em nome não só do progresso e da história, mas sobretudo de Deus..., o Deus do protestantismo. Como analisou Marx Weber, o protestantismo está constituído pelo éthos puritano da organização racional do capital e do trabalho, para acumular 
recursos a serem aplicados e re-aplicados na contínua expansão e ampliação da "obra de Deus na terra", a ininterrupta e obcecada evangelização, a conversão do outro, "pagão".

A "conquista do oeste" foi constituída sob as bases étnicas do protestantismo, justificando frases como do general Sheridan, ante a afirmação de Tosawi da nação comanche: “ - Tosawi, bom índio", Sheridan respondeu: "- os únicos índios bons que vi já estavam mortos;" que se transformou num famoso aforisma genocida. "índio bom, - só índio morto".

Chivington, ex-pastor metodista, descumpria qualquer tratado estabelecido com os índios, e justificava terríveis massacres. Escolhido para comandar as ações militares de incorporar a terra de Sand Creek dos Cheyennes e Arapahos, discutiu com alguns oficiais que resistiam a seus métodos, e na ocasião exclamou: - "Maldito seja qualquer homem que simpatiza com os índios... "vim para matar índios e acho que é certo e honroso usar qualquer modo sob o céu do Senhor para matar índios." E sobre o massacre de crianças e mulheres, mesmo as grávidas, sentenciou: "Dos ovos é que nascem os piolhos".

A vinda crescente de africanos para os Estados Unidos gerou conflitos de interesse sócio-econômicos que culminaram com a guerra de secessão. $\mathrm{O}$ fim do tráfico escravagista, a abolição, e novas reservas de mercado industrial, transformaram a sociedade americana.

Por outro lado, se estabeleceram políticas de promoção de retorno dos africano-americanos para a África, chegando a fundar um país, a Libéria, e ainda fazendo propostas ao Brasil, envolvendo a Amazônia, mas que fracassaram.

Também foram criadas políticas para estabelecer limites de espaços entre negros e brancos, concretizando um sistema de apartheid de convívio social, e de divisão de trabalho, ficando os primeiros situados a mercê do mercado de trabalho mais desvalorizado.

Mas o sistema imperial americano, baseado na dollar diplomacy, teve de conviver com nações concorrentes e de apresentar outras faces de "país desenvolvido e civilizado" se caracterizando como "pátria da liberdade e da democracia", defensora do "mundo livre" e dos direitos humanos, país sede da ONU.

Em meio a esses intertícios, caminhou a luta de afirmação existencial da comunidade negro-americana, procurando jeito de viver.

Grande parte acabou tendo de aderir ao protestantismo e silenciar os atabaques. Muitos se tornaram pastores ascéticos e puritanos, como bem ilustram os personagens dos filmes Febre da Selva e A Cor Púrpura, capazes de renegar até os filhos que representavam outras referências de identidade, já afogadas, porém, em angústias banhadas de álcool e delírios de drogas...

Outros se enganaram no exército, se empregaram na polícia, estudaram nos livros, criaram escolas e universidades; alguns penetraram sedutoramente 
na indústria cultural, destacaram-se nos esportes... Reivindicaram os direitos civis, fim do racismo, a tal sonhada integração...

Outros ainda tentaram, já num vazio cultural e religioso próprios, erigir uma identidade, apelando a um islamismo superficial e simbólico ...

Lutaram através de guerrilhas urbanas, queimaram os símbolos mentirosos do American way of life veiculados massivamente por Hollywood, supermercados, lojas, shopping centers, - burn baby burn...

Quantos morreram... Até mesmo o líder da luta pacífica, o rev. Martin Luther King, assassinado.

Por outro lado, ainda, quantos morreram no exército, nas guerras mundiais, no Vietnam, em diversas partes do mundo onde estende-se a mão armada dos EUA, inclusive recentemente na área muçulmana do Iraque.

Conseguiram vitórias?! Tornaram-se cidadãos de iguais direitos?! Puderam votar e ser votados.

Elegeram parlamentares prefeitos, governadores. Tentaram a presidência.

Parecia que havia um processo de mudança, que a Klux Klux Klan, era coisa do passado...

Figuras como Michael Jackson, Mike Tyson, Magic Johnson ocupando um espaço na mídia de forma inusitada.

De repente, o que vemos, uma reação?! Para manter o espaço e derrubar a ideologia racial, Michael Jackson transcende o estigma das cores, e mais, a própria cor... Mike Tyson é desmistificado no rinque. E pior, processado e condenado, enquanto acintosamente o rapaz dos Kennedy é absolvido das mesmas acusações...

Magic Johnson contrai aids, tentando de todos os modos manter-se digno nesta condição dramática...

São alguns sintomas da vida cotidiana que indicavam que o sonho africano-americano, ainda mais num contexto de recessão econômica, estava sendo atravessado por penumbras de um antigo e permanente pesadelo.

Culminou sendo obnubilado com o episódio da absolvição dos policiais em Los Angeles. A etnia anglo-saxônica resolveu demonstrar que a hegemonia do poder é absolutamente dela. Liberou fantasmas dos castigos escravocratas...

E então, o fogo ardeu, burn baby burn, num protesto desesperado, tentando a purificação, para que das cinzas possa surgir quem sabe, uma nova forma de convivência social. Cerca de cinqüenta jovens negros morreram, nesta terra em que os atabaques não comem, a não ser os que chegam do Caribe.

\footnotetext{
Notas

${ }^{1}$ Cf. Nascimento, Abdias. O Genocídio do Negro Brasileiro, Rio de Janeiro, Paz e terra, 1978

${ }^{2}$ Cf. Brown, Dee. Enterrem meu Coração na curva do Rio, Rio de Janeiro. Ed. Melhoramentos, 1986.
} 


\section{DEMOCRACIA E DIVERSIDADE HUMANA*}

O seminário nacional - Democracia e Diversidade Humana: Desafio Contemporâneo, organizado e realizado em Salvador, pela SECNEB, Sociedade de Estudos da Cultura Negra no Brasil, no mês de março de 1992, com apoios diversos, inclusive de órgãos dos governos federal e estadual, se revestiu de profundos significados e grande repercussão.

Neste artigo, procuraremos sumariamente ressaltar as proposições que nos parecem de maior interesse e importância nas exposições e debates desenvolvidos.

Procurando seguir a ordem temática dos trabalhos, realçamos desde logo que a pluralidade cultural e a diversidade humana constituinte da nacionalidade brasileira, aponta para um processo histórico marcado por conflitos, explorações e exclusões na constituição e caracterização da sociedade oficial.

Resumindo todo este panorama histórico social, pode-se dizer que o Estado é hoje caracterizadamente de bases europocêntricas, positivistas e produtivista, e até mesmo racista na sua constituição e projeção ideológica de concepção de República, alijando do exercício do poder de Estado importantes segmentos populacionais das vertentes civilizatórias ameríndia e de origem africana.

É nesse sentido que se pode falar de nação inconclusa, pois o Estado nacional não contempla os valores, as necessidades e aspirações da grande maioria da população, não legitimando e mesmo recalcando e excluindo de seu contexto a pluralidade sócio-cultural brasileira, fixando-se em paradigmas europocêntricos na constituição da República, envolvendo o conceito de democracia.

\footnotetext{
* Artigo publicado no Caderno Cultural do Jornal A Tarde, em 1992.
} 
Mas na atualidade, no momento em que a força das referências étnicas emergem em movimentos sociais na própria Europa, provocando mudanças inesperadas pelo repertório científico positivista, começa cada vez mais o pensamento social a avançar na direção de procurar entender a pluralidade étnica como fator de constituição e transformação dos Estados nacionais. Todavia não só a etnia, strictu sensu, mas a diversidade de identidades, a questão da alteridade, está sendo cada vez mais colocada na ordem do dia das problematizações da intelligentzia no Ocidente.

É neste sentido, de uma revisão crítica, a partir de um despojamento e superação de ideologias recalcadoras e preconceituosas, que se pode, por exemplo, perceber e reconhecer o quanto de valores e conhecimentos, as sociedades indígenas brasileiras podem, na atualidade, promover de enriquecimento humano aos cidadãos ditos "civilizados".

As formas de organização social, os comportamentos adotados nas sociedades indígenas tradicionais, podem, sem sombra de dúvida, alimentar novos paradigmas de democracia, de respeito ao outro diverso e à natureza. Eles podem constituir-se em fontes de inspiração para o objetivo de construção de novos valores democráticos no âmbito da sociedade oficial em mudança.

Através de uma visão sagrada de mundo, que cria e reforça os vínculos e alianças comunitárias, a elaboração das alteridades, promovendo o acesso democrático à produção, à conservação da terra, aos conhecimentos da natureza etc., há, em comparação com a sociedade dita civilizada, grande harmonia que enriquece a vida nas sociedades indígenas e revela o porquê se deve unir forças para a sua defesa. Essas sociedades detêm um valioso e sofisticado patrimônio cultural milenar, que mais do que nunca, tem um grande interesse de aprendizagem para a sociedade global, para que ela mesma não se destrua na anomia do salve-se quem puder que vai se instalando, conseqüência da falência dos valores impositivos de referências neo-coloniais europocêntricas, inadaptáveis as características civilizatórias do povo brasileiro, basicamente de origem ameríndia e africana.

Mais que isso, a forma de ocupação do espaço-território dentro do paradigma neo-colonial, produtivista, positivista vem colocando a própria continuidade de existência do planeta em perigo, uma ameaça constante a biodiversidade.

Em contraposição, também, as comunidades tradicionais africanobrasileiras, através de suas elaborações sagradas de mundo, se relacionam com o outro diverso e com a natureza de forma a garantir a perenidade da existência.

Os princípios de interdinâmica entre este mundo e o além, concretizados através da circulação de força sagrada promovido pelos rituais do culto aos ancestrais e às distintas forças complementares que governam a natureza e o universo, se constituem em referências profundas às mais significativas proposições de bem existir. 
Evidentemente, que não como proposição de caráter catequético, messiânico salvacionista, mas como fonte inspiradora que elabora os diferentes princípios complementares constituintes da existência.

Mas, para tanto, é preciso ultrapassar os obstáculos político-ideológicos para a legitimação da fala ou da palavra emergente das comunidades negras tradicionais.

Um deles, bastante significativo do poder de Estado europocêntrico positivista é a referência à escrita, um dos pilares de sustentação da forma imperialista de comunicação no Ocidente.

Isto porque, a escrita neste contexto, se constitui num pressuposto que desqualifica as demais formas de comunicação, especificamente a linguagem da tradição africana

Este obstáculo europocêntrico é sobretudo um recalcamento ou encobrimento das formas próprias de comunicação das comunidades da tradição africano-brasileira, onde a escrita possui papel secundário, pois a palavra carregada de força sagrada exige uma comunicação direta, interdinâmica, pessoal ou grupal.

No contexto da tradição, a palavra dos que detém poder sagrado, axé para os nagô, os iniciados mais antigos, entra em interação ritual promovendo as relações entre este mundo e o além. A palavra é propiciatória, e está revestida também de uma dimensão estética assentada nos diferentes códigos e repertórios ao acervo cultural da tradição e que reforçam sua expressão contextual.

$\mathrm{Na}$ transmissão das mensagens neste contexto, exigem-se outras posturas de leitura que não apenas a relação olho-cérebro, percepção-abstração, característica da comunicação escrita, impessoal, individual, indireta.

Portanto, a comunicação participativa da tradição transmite o saber e o conhecimento, apelando a todos os sentidos, promovendo distintas sensações e emoções que promovem elaborações em meio ao processo do partilhar de paixões comuns que reforçam a identidade do grupo e os vínculos e alianças comunitárias.

Não se pode falar de "analfabetismo" neste contexto, mas de diferente forma de leitura que aquela da escrita.

É a partir deste ponto de vista que se pode abrir os umbrais da percepção europocêntrica, e entrar em interação com uma rica e complexa visão de mundo milenar, que por outro lado irradia valores que inspiram o viver sóciocomunitário e constitui uma das mais importantes maneiras de ser e de vida da população brasileira, sobretudo, na Bahia.

É preciso sublinhar também que os terreiros realizam uma intensa relação dialética entre a continuidade da tradição e a sociedade diversa envolvente. Como se referia a Iyalorixá Iya Nassô, Mãe Senhora Axipá, uma dinâmica "da porteira para dentro, da porteira para fora". 
Neste contato se produz uma significativa quantidade de expressões sócio-culturais através da ação de determinadas instituições, da atuação de sacerdotes e sacerdotizas, de artistas, intelectuais, etc., dentre as quais este próprio seminário é um dos mais lídimos exemplos.

O seminário, por outro lado, indicou também a dimensão profunda da psique, que alimenta as formas de discriminação da alteridade características das sociedades ocidentais, e que conduziram a humanidade à beira da destruição do planeta, em meio a inaudita exploração da força de trabalho e da natureza, promovendo genocídios e destruições.

O que constitui a denegação ou a discriminação da alteridade, do diferente, da rejeição do outro, neste contexto, é o medo do desconhecido, que, em última instância, é o temor aterrorizante para os ocidentais da angústia existencial provocada pelo mistério da origem e da morte, que por outro lado assemelha-os com toda a humanidade.

O que os distinguem é a dificuldade que a cultura ocidental possui de elaborar essa angústia, o que cria mecanismos psíquicos de defesa que alimentam uma postura narcísica onipotente, que tem por conseqüência a projeção no outro de tudo o que é de mal e negativo, denegado em si próprio.

Para alimentar essa onipotência narcísica, acaba essa cultura realizando o que projeta no outro, explora, extingue, destrói, repetitivamente como verdadeira mania.

Para se alcançar novos patamares de valores que propiciem a continuidade da vida no planeta de maneira mais pacífica e harmoniosa, é preciso portanto a superação dos paradigmas culturais positivistas do Ocidente, reconhecer e assumir suas limitações, e abrir-se para a compreensão e a aprendizagem com civilizações e culturas milenares que se constituem a partir das elaborações míticas sagradas da origem do destino e da morte. Como reza o ditado nagô, certa vez pronunciado pelo Otum Alagba nilê Agboula, Sr. Cosme Daniel de Paula: "neste mundo, somos galinhas de Deus"...

Por fim, não poderíamos deixar de registrar, também, as limitações ideológicas-epistemológicas dos conceitos de classe e gênero como insuficientes para abranger a diversidade humana e a pluralidade sócio-cultural característica das composições e inúmeras nações, e especificamente em relação à identidade brasileira. Esses conceitos, o mais das vezes têm se mostrado inoperantes para a compreensão da complexidade nacional, e conseqüentemente para erigir políticas que efetivem as aspirações dos diversos segmentos da população, na construção de um novo paradigma de valores democráticos. 


\section{NA DIVERSIDADE HUMANA, TODO}

SANGUE É VERMELHO

Dois eventos marcaram substancialmente o panorama intelectual brasileiro, no ano de 1994, a saber: O Encontro Internacional Diversidade Humana Desafio Planetário, realizado pela Sociedade de Estudos da Cultura Negra no Brasil -SECNEB, em Salvador, e o IV Congresso Afro-Brasileiro realizado pela Fundação Joaquim Nabuco, em Recife.

Foram dois eventos distintos na sua forma e objetivos. O primeiro procurando concentrar-se e aprofundar conceitos e questões relacionadas aos problemas étnico-políticos da atualidade, buscando princípios que possam estruturar uma nova ética de convivência mais harmônica entre povos diversos, e o segundo, por sua vez, de maior amplitude, procurando captar os distintos matizes dos estudos relacionados à população negro-brasileira.

O que porém trataremos de sublinhar, é que no esforço de aprofundar conceituações em torno dos problemas que afligem a humanidade no que se refere à dimensões étnico-políticas, a SECNEB procura fundar um novo continente epistemológico, uma nova problemática teórica que permita dar respostas efetivas as questões propostas.

Para tanto, é preciso superar determinados obstáculos teórico-ideológicos que restringem e não permitem a fundação de uma nova episteme que abrigue as questões da diversidade humana e os problemas que envolvem a alteridade, assim como a semelhança, pois que todo sangue é vermelho...

Desde o Seminário Democracia e Diversidade Humana: Desafio Contemporâneo, realizado em 1982, pela SECNEB, que uma indagação ou sábia provocação de Emílio Rodrigué, foi lançada: "será que o conceito de raça é racista?"

Procuraremos tecer algumas considerações tentando caracterizar a intencionalidade da indagação. Perguntaríamos : será que o "conceito" criado para operacionalizar as teorias do racismo poderia ser utilizado noutro contexto 
sem a sua essência ideológica de dominação. E, por outro lado, que conteúdo científico ou de real conhecimento pode expressar a noção de "raça”?

A expansão ideológica da noção de raça se deu através das teorias de Lapouge e Gobineau, no fim do século XIX, quando ocorrem os processos abolicionistas e se instala uma nova forma de dominação nas nações recémindependentes ou neocolonizadas. Ela sustenta critérios ideológicos de desigualdades entre a população para qualificar a cidadania no âmbito da criação dos chamados Estados modernos após a revolução francesa.

O importante a destacar é que o racismo é construído teoricamente no continente epistemológico do evolucionismo e do europocentrismo, caracterizando a "superioridade" dos povos brancos sobre os não brancos.

É sobre esse campo ideológico que se estabelecem as bases dos Estados nacionais e se formam políticas de apartheid e de embranquecimento.

No Brasil, durante o império, a política de embranquecimento do Estado europocêntrico caracterizou-se, de um lado, pelo fim da vinda de africanos e, de outro, pelo estímulo à imigração de europeus. Isso acarretou a invasão das terras indígenas no sul do país, o genocídio dos Xokleng, a dizimação das florestas, para a ocupação dos europeus.

Na conta do genocídio do tempo imperial ainda observa-se o "fenômeno" da guerra do Paraguai, onde a grande maioria de mortos foram dos descendentes de africanos e de indígenas; segundo algumas fontes, a população negra no Brasil teria baixado em torno de 60 \% com essa guerra estimulada pelo império britânico.

Com a abolição uma nova faceta do genocídio, ou seja, a política de abandono, quando milhões de pessoas são largadas à própria sorte numa economia centrada e controlada em geral pelas etnias brancas. É a chamada política da fome, com todas as conseqüências que atingem a população não branca em geral.

O racismo articulado com o positivismo, também evolucionista e europocêntrico, caracterizará o solo ideológico donde se ergue o Estado republicano.

A tragédia de Canudos é o maior sintoma de que o Estado tentaria não permitir formas de sociabilidade autônomas de defesa e afirmação da própria população não branca ante as políticas genocidas; ainda aqui são os discursos racistas e positivistas que legitimam as ações aterrorizantes do Estado, uno, totalizante, que estabelece a lei e a "normalidade" imposta pelo processo de criação de um mercado de bens industriais: "ordem e progresso".

Com a situação histórica criada pela ascensão e a queda do nazi-fascismo, a problemática do racismo entra em crise e simultaneamente em processo de reformulação.

No Brasil, essa reformulação teve duas características teóricas peculiares. Baniu-se a noção de raça, uma vez derrubada pela Biologia que afirmava, do ponto de vista biológico, que nada há na estruturação genética dos seres 
humanos capaz de qualificá-los na direção proposta pelo racismo. Todavia, manteve-se o campo positivista, evolucionista e europocêntrico na constituição de novas ideologias que iriam sustentar a ideologia da "democracia racial". Uma dessas ideologias é a higienista, de combate as "culturas atrasadas" ou "neurotizadas", outra é a ideologia da "mestiçagem" e do "sincretismo". A primeira, constituída e divulgada no Brasil por Arthur Ramos. Ambas procuram legitimar uma ordem social de um Estado europocêntrico.

Não vamos aqui aprofundar-nos na crítica a essas construções teóricoideológicas, o que aliás já o fizemos, especialmente no livro Cultura Negra e Ideologia do Recalque.

O que iremos marcar, porém, é que ambas recalcam a diversidade, a alteridade própria, a identidade estruturada pelas civilizações dos povos aborígenes e dos descendentes de africanos e outros brasileiros que vivem os valores e linguagem deste acervo civilizatório nacional. Essas ideologias teóricas concorrem para a política de deslegitimação da cidadania da maioria da população brasileira, de suas instituições comunitárias e reforçam a manutenção do estado uno europocêntrico de características neocoloniais.

Desmascarar o evolucionismo e o etnocentrismo como ideologias neocoloniais já foi realizado pelas Ciências Humanas, especialmente através dos trabalhos de Levi Strauss.

Fica fácil perceber, a partir de então, as tentativas de Arthur Ramos de criar linhas de ação "psico-pedagógicas" com a finalidade de, através de sua percepção deformada da cultura afro-brasileira, atacá-la em sua legitimação e procurar concorrer para políticas educacionais capazes de afastar o brasileiro dessa riquíssima tradição.

Assim podemos perceber também o europocentrismo de Gilberto Freire, sua tentativa de lisongear a população negra por ser capaz de erguer uma civilização européia nos trópicos devido a sua "adaptabilidade climática", sob o comando dos brancos...

Chega a ser risível, se não fosse trágico, a ideologia da "mestiçagem" e do "sincretismo" que daria o tom moreno e tropical a essa "civilização brasileira", apagando o riquíssimo legado civilizatório milenar aborígene e africano, mantido pela continuidade da descendência dos ancestrais cuja memória e honrabilidade cabe manter e tomarmos como componentes essenciais de nossa identidade nacional.

Diferentemente dessas ideologias repressivas e recalcadoras da diversidade humana e civilizatória dos povos que compóem a nacionalidade e que dão continuidade as suas dinâmicas de tradição, apesar do estado uno e totalitário, a nova problemática que se instala para além da noção vazia e oca de raça, procura perceber a alteridade própria e a identidade através dos processos de sociabilização. 
O psicanalista Fábio Lacombe, durante o Encontro Internacional da SECNEB, sublinhou que mesmo a construção das noções de pai e mãe são dadas e testemunhadas culturalmente. O recém-nascido só poderá vir a localizar-se no núcleo familiar pela cultura, pelo acesso ao simbólico pela linguagem e éthos.

Podemos dizer, pois, que é a partir de determinada cultura já dada que começa a construção da identidade e a noção da alteridade por gerações e gerações.

No entanto, as culturas e os processos civilizatórios são múltiplos e variados, uma característica da humanidade cuja origem se perde na noite dos tempos.

Hoje em dia, com a crise dos Estados imperiais, o desfazimento da União Soviética e os problemas políticos e bélicos entre povos que procuram afirmar sua identidade reivindincando cada vez mais direitos de territorialidade e de existência própria, somente uma nova ética de relações entre as variadas etnias e povos, gerando formas pacíficas de negociação, poderão evitar genocídios.

Assumir a riqueza da humanidade, que é sua diversidade e multiplicidade de formas de sociabilidade, significa abandonar a ética da subjugação e imposição de uma univocidade de ser procurando esvaziar a identidade do outro. Implica, por outro lado, na aceitação da alteridade própria como princípio capaz de engendrar uma ética que proporcione novas formas de negociações dos problemas emergentes em determinados contextos sociais.

Esta é para nós a possibilidade real de uma nova ordem nacional e mundial, mais equilibrada e harmônica. E não esqueçamos: para além da diversidade, todo sangue é vermelho. 


\section{PINDORAMA, BRASIL, ILÉ-AXÉ 500 Anos Depois a Terra está em Perigo*}

No momento que se realiza a ECO Rio 92, e se mobiliza de forma inusitada tantos representantes de povos, nações e governos de diferentes partes do mundo, somos motivados a refletir sobre as origens de um processo, em que estamos todos inseridos, e que ora culmina na necessidade de uma reunião de tal porte para se pensar: "Como salvar o planeta!?"

Salvar, porque há ameaças para a vida humana, cessadas as fontes de suprimento das necessidades dessa espécie, por conta do desgaste do ecossistema do qual faz parte, principalmente os povos do hemisfério norte, hoje praticamente dependentes do que permanece no hemisfério sul.

Procuraremos responder, sumariamente, ao porque chegamos a esse ponto indagando sobre as origens, isto é, os pontos de ancoragem epistêmica em que se fundam as civilizações, de onde se desdobram os valores pelos quais se organizam, produzem e agem em todos os sentidos aqueles que as integram.

Tentaremos ilustrar com alguns mitos fundamentais, os paradigmas de formas de vida estabelecidos nas civilizações que constituíram nossa nacionalidade, ou seja, as ameríndias ou aborígenes, as européias e as africanas. Começaremos a nossa abordagem pela mais nova e terminaremos com as mais antigas.

A arkhé, ou ponto de ancoragem da civilização européia, se concentra nos princípios originários das culturas greco-romana e judaica.

Tomaremos como referência a idéia de um movimento pendular desta civilização onde, de um lado, situam-se princípios prometéicos, e de outro lado, dionisíacos. Os primeiros se desdobram do mito trágico de Prometeu, que roubou o fogo de Zeus, e entregou aos homens, pagando por isto o castigo de ficar acorrentado nos penhascos, entregue a sanha dos abutres.

\footnotetext{
* Artigo publicado no Caderno de Cultura do Jornal A Tarde, 1992.
} 
Como narra o mito, é dessa forma que o fogo vem parar na mão dos homens nas elaborações da cultura européia. Um poder divino usurpado, que promove o conhecimento e o desenvolvimento tecnológico, e que envolve uma forma determinada de organização social, voltada para sua promoção.

Por outro lado, os princípios dionisíacos estão assentados sobretudo na comunhão ou reunião da pólis, para compartilhar sentimentos e paixões características ao culto à fertilidade da mãe terra, pródiga e misteriosa natureza, que aplaca a angústia existencial num estar junto comunal, segundo alguns sociólogos, origem da sociabilidade.

O Renascimento marcará a predominância pendular dos princípios prometéicos, ajustando princípios judaicos e cristãos às inspirações imperiais romanas, promovendo novo ciclo de conquista de territórios e povos para além do continente europeu em busca do "caminho das índias", alcançando a extensão litorânea dos continentes africano, americano e asiático.

O livro do Gênesis 1, 28, 29, base da cultura judaica, erige referências em relação à natureza ajustada ao impulso prometéico...

crescei e multiplicai-vos, e enchei a Terra, e tende-a sujeita a vós, e dominai sobre os peixes do mar, sobre as aves do céu, e sobre todos os animais que se movem sobre a terra. Disse-lhes também Deus: Eis, aí vos dei eu todas as ervas, que dão as suas sementes sobre a terra; e todas as árvores, que têm suas sementes em si mesmas... para vos servirem de sustento a vós...

Conseqüentemente, vive-se um sistema de vida em que pode-se dizer, segundo José Carlos Rodrigues , que "200 milhões de americanos consomem e poluem mais do que o fariam 5 bilhões de índios."

O princípio prometéico se combinou não só com a idéia de "povo eleito por Deus" do judaísmo, mas também com os valores ascéticos da noção de pecado incorporado pelo cristianismo, a sua vocação catequética e evangélica; a percepção do outro como "pagão" portador do pecado original a ser convertido. Portanto, a negação do direito à alteridade própria.

A predominância de princípios prometéicos sustentaram a tensão de repressão às pulsões dionisíacas, aos princípios femininos envolventes do mistério da mãe terra; e, por outro lado, estimularam a vocação patriarcal, fálica, conquistadora e avassaladora que caracteriza a bacia semântica dos valores de organização social da modernidade.

A chamada "era dos descobrimentos" está assentada nesses princípios. O estímulo ao desenvolvimento científico-técnico-militar proporcionava as grandes navegações que deram início ao processo de acumulação de poder e riqueza à Europa. Onde houvessem territórios ocupados por “pagãos", a igreja católica asseguravas aos cristãos a legitimidade de sua ocupação bélica, garantia de exploração de trabalho e das riquezas naturais. 
O que se segue nesses quase quinhentos anos de predomínio dos princípios prometéicos, e chega até os nossos dias, é o mercantilismo, o colonialismo, o tráfico escravagista e a escravidão, a exploração exaustiva e poluição da natureza, o imperialismo, guerras e genocídios...

Tudo isso está representado condensadamente pela acumulação de capital ou dinheiro, forma abstrata de valor que caracteriza o poder hegemônico daquelas nações que impulsionam este processo derivado dos princípios prometéicos que englobam também a bacia semântica dos positivismos.

Mas deixemos nossa herança européia que sustenta as bases do paradigma prometéico-positivista do Estado brasileiro, "ordem e progresso", e passemos a nossa herança aborígene.

Um mito de vários povos, especificamente os Nambikwara, narra como o fogo foi parar nas mãos da humanidade.

O tio levou o sobrinho pela primeira vez à floresta para caçar. Logo, ele avistou no alto de uma rocha um ninho de araras. Colocou um tronco encostado na pedra e falou para o sobrinho subir e lançar-lhe os ovos. Chegando no ninho, o sobrinho teve dó dos filhotes e se negou a fazer o que o tio pedia. Este, depois de insistir um pouco se aborreceu, e tirando o tronco deixou o sobrinho pra lá. Foi então que apareceu a arara, vendo o menino perto do ninho não gostou, protestou, fazendo cocô em cima dele e causando tanto alvoroço que chamou a atenção da onça que por ali passava. Esta, vendo o menino naquela situação resolveu ajudá-lo, colocando o tronco, para que descesse e levou-o para sua casa. Lá chegando, preveniu-o do mal humor da sogra e deu-lhe o arco e a flexa para se defender e foi-se mata a dentro. O menino viu a sogra da onça comendo um moqueado de carne. Depois que ela comeu, ele que estava com fome, resolveu se servir da carne que já estava muito assada e na sua boca fazia nhec, nhec, o que irritou a onça. Ela começou a rosnar mostrando os dentes.

Foi então que ele lançou uma flexa e fugiu levando um tição com fogo. Caminhou, caminhou, até que deparou-se com a aldeia.

Surpreendidos com o fogo, os guerreiros lhe indagaram, e cientes de tudo foram até a toca da onça, onde pegaram todo o fogo, passando de uns pros outros, de mão em mão, trazendo para a aldeia.

Uma pequena brasa que restou o sapo cuspiu e apagou, de modo que foi assim que, só a humanidade detém o uso do fogo. ${ }^{2}$

Meditando sobre a história, a antropologia nos indica ser uma representação e elaboração dos limites entre sociedade e natureza, envolvendo o processo de iniciação-socialização, que faz do menino um adulto, diferenciandose da natureza, integrando-se às regras de cooperação e convivência social.

Mas o que desejo ressaltar é que o fogo, neste contexto, pode representar a pulsão da sociabilidade, o estar junto em volta da fogueira compartilhando sabedoria e emoções, a harmonização de convivência social humana, e a diferença da espécie, o cru e o cozido... 
Esta satisfação comunal está distante dos valores individuais da mítica do self made man, dos heróis à Marco Polo que caracterizam o ideal de ego prometéico do processo civilizatório europeu, da mítica tecnológica, em que um pode destruir milhares, como o piloto que lançou a bomba atômica em Hiroxima...

Mas avancemos em torno de outra herança, a dos povos africanos que para aqui vieram trazidos pelo tráfico escravagista, principal fator econômico do mercantilismo das Companhias das índias.

Um ditado nagô afirma: "Kosi ewe, Kosi orixá", sem folhas não há orixá, não há existência.

O conto "Odé e os Orixá do Mato" narrado em livro por Mestre Didi, Alapini, adaptado por ele para um auto-coreográfico, se tornou a peça principal da experiência de educação pluri-cultural da Sociedade de Estudo da Cultura Negra no Brasil - SECNEB, denominada Mini-Comunidade Oba-Biyi.

$\mathrm{O}$ conto narra que uma vez um famoso caçador, possuidor de poderes extraordinários, certo dia não conseguiu um só bicho. Pior é que nos dias que se seguiram também, até que seus suprimentos acabaram e ele teve que retornar da mata.

Então ele foi direto consultar o babalawô - pai do mistério - para saber o que se passava.

Soube que a razão de tudo era que havia muito tempo que ele nada fazia para a floresta. Cabia então ele oferecer aos pés de Iroko, Gameleira sagrada, uma oferenda de fumo, aguardente e mel, e pedir ao orixá sua proteção para devolver-lhe seus poderes.

Depois de ter pago ao babalawô e feito as oferendas prescritas ao pé de Iroko, logo apareceram vários bichos a sua volta. O caçador se pôs a caçá-los, e eufórico foi matando a todos que apareciam, arrastando-os para uma choupana improvisada.

Exausto e com fome, escolheu uma ave abatida para assar. Foi quando, de repente, apareceu um pinto molhado.

O caçador ficou perplexo e assustado quando o viu, e mais ainda quando ouviu uma voz saindo do fundo da mata:

Estevão, Estevão...

O pinto respondia:

- Oi, home.

- Venha e traga os outros.

- E ele também?

- Ele deixa pra depois.

Em seguida, ele foi chamando um por um a todos os bichos, que seguindo o pinto se adentraram pela mata.

O caçador, apavorado, pegou o que lhe restava, a ave assada e seus pertences, dizendo que jamais voltaria à mata, e foi para a cidade. 
Mitos milenares da tradição africana no Brasil nos alertam o que pode acontecer com o abuso dos poderes. O mistério que envolve a existência, a restituição, a renovação, a continuidade e expansão.

$\mathrm{Na}$ origem de sua denominação, nosso país é concebido como Santa Cruz e logo Brasil, demonstrando que os valores do mercantilismo sobrepuseram-se aos religiosos que legitimaram a conquista européia pelo Papa. No contexto mercantilista, o pau-brasil, matéria-prima para manufatura européia, hoje está praticamente extinto.

Será essa, inexoravelmente, nossa vocação. Território de exploração de matéria-prima para enriquecimento dos europeus na Europa ou nas Américas, em detrimento de sua própria população; país que não cessa de exportar o que tem progressivamente. E, os europeus agora começam a se perguntar, e se extinguir-se essa fonte de alimento e energia, como ocorreu com o pau-brasil, e pior, com a bio-diversidade em seus próprios territórios?!

Estará na hora de refletirmos sobre a adequação do nome Brasil, resultante do paradigma mercantilista positivista dos tempos modernos, agora em crise, no alvorecer pós-moderno das preocupações ecológicas, tendências dionisíacas!?

Poderíamos então sugerir Pindorama, a terra das Palmeiras, como denominaram aqueles que aqui estavam quando da chegada dos europeus. Ou ainda Ilé Axé, terra de axé, de dinamização dos princípios cósmicos que regem o universo, característico das valores de nossa herança africana. Ou ainda numa homenagem aos princípios o universo e aos povos fundadores do território, simplesmente Amazônia, você sugere, você decide...

\footnotetext{
Notas

${ }^{1}$ Rodrigues, José Carlos. O Tabu da Morte, Achiamé, Rio de Janeiro, 1983, p. 247.

${ }^{2}$ Cf. Melatti, Júlio César, in Mito e Linguagem Social, Tempo Brasileiro, Rio de Janeiro, 1970.

3 Cf. Santos, M. Deoscoredes, Mestre Didi, in Identidade Negra e Educação, Ianamá, Salvador, 1989.
} 



\section{O LÚDICO E O SAGRADO}

A Olimpíada, todos sabemos, surgiu na Grécia antiga, uma das referências de origem mais significativas do imaginário da constituição da civilização européia.

O que muitos não sabem, porém, é que a cultura grega floresce do contato com múltiplas culturas e civilizações, especialmente a egípicia, com o patrimônio de seus conhecimentos religiosos, filosófico-míticos, históricos, matemáticos, físicos, astronômicos, de engenharia, arquitetura, de estética, escultura, pintura, literatura, de técnicas de medicina, agricultura, etc. Isto porque o próprio contexto europeu moderno, de predominância ideológica positivista-colonialista de um lado, recalcou, silenciou e deformou a pujança da civilização negro-faraônica, e de outro, atribuiu os créditos de todas as fontes de conhecimento da Europa à civilização greco-romana, para eriji-la em paradigma adaptado ao Estado colonial, imperial, escravista, origem da modernidade.

$\mathrm{Na}$ verdade, Atenas, "berço da democracia", era uma sociedade de predominância mercantil, rigidamente estratificada, onde os escravos constituíam a maior parcela da população.

Esparta, constituída através da dominação e exploração dos hilotas, se caracterizou por valores eminentemente militares, vida de caserna, corpos e mentes disciplinados pelos exercícios ininterruptos.

Nada mais pertinente, portanto, que no contexto da era moderna, quando várias instituições se constituíram inspiradas na ideologia da grandeza da civilização greco-romana, a retomada dos jogos olímpicos tivesse também destacado lugar.

No contexto imperial industrial de disputas de mercado entre nações beligerantes, o esporte olímpico se constituiu num grandioso teatro mundi de afirmações de supremacias políticas, econômicas e étnicas... 
A Olimpíada de Berlim é o exemplo mais famoso, quando Hitler apostou na consagração da "raça ariana" e o tiro saiu pela culatra. As medalhas de ouro obtidas pelo africano-americano Jesse Owens fizeram muito mais pela derrota do nazismo que inúmeros regimentos aliados em combate bélico.

No período da guerra fria, EUA e URSS travaram encarniçadas disputas pelas vitórias nos jogos.

A frase do francês Coubertin, fundador da Olimpíada moderna, "o importante é competir", nesse contexto de disputas de supremacias imperialistas é tão vazio quanto liberté, egalité, fraternité da república francesa pós-revolução.

Hoje, todavia, as tensões políticas estão relativamente amenizadas. Os Estados oriundos desta conjuntura estão em crise, novos valores estão aqui e ali alimentando novas utopias, principalmente as resultantes do desrecalcamento de culturas e identidades próprias dos povos que mantiveram suas tradições para além dos limites sócio-culturais produtivistas, positivistas, evolucionistas.

Alguns intelectuais referem-se a esse novo horizonte histórico como pósmodernidade. É o que de certa forma Michel Maffesoli descreve como movimento pendular do esprit du temps, espírito do tempo, que oscila entre as dimensões dionisíacas e prometéicas da existência humana.

Na pós-modernidade, caracterizada pela ênfase da pulsão dionisíaca, a dimensão estética do viver, isto é, o compartilhar de sentimentos, emoções e paixões comuns, ganha relevância na constituição da potência comunal, responsável pela afirmação dos vínculos e alianças comunitárias, relações societárias.

É nessa ambiência que é possível reconhecermos o significado, o espaço e a evidência do Dream Team, a equipe de basquete masculina dos EUA na Olimpíada de Barcelona, dando a ela o matiz mais forte de seu esplendor.

Algumas digressões sobre o lúdico, o jogo, e o sagrado permitirão entendermos melhor essa performance.

O sagrado e o lúdico são manifestações das dimensões características da vida humana.

O sagrado procura amenizar a angústia existencial relativa aos mistérios da existência, através de elaborações e ritualizações diversas sobre a origem e o devir. Por outro lado, ele promove também a satisfação do desejo de estarjunto, origem da vida societária.

As exigências produtivistas-mercantilistas das sociedades industriais atropelaram a temporalidade e a espacialidade do sagrado, tentando esvaziar sua significação, recalcando as linguagens míticas e místicas através do enaltecer da técnica e da ciência, sobretudo reprimindo as alteridades, através da denegação da morte, o outro que há em nós mesmos, e pelo qual deixaremos de ser o que somos agora, transformando-nos um pouco a cada dia que passa, nesta ininterrupta e inexorável sucessão do ciclo de morte-renascimento, do qual todos fazemos parte. 
Neste sentido, a presença de Magic Johnson nos jogos é uma pontuação a mais entre o lúdico e o sagrado no contexto atual da aceitação da alteridade.

Esse fato é bastante significativo, pois se as instituições, a temporalidade e a espacialidade do sagrado, especialmente aquelas não identificadas com o "livro sagrado", foram afastadas ou racalcadas pelo Estado positivista, neste âmbito, a libido da socialidade, a pulsão do estar junto nas elaborações sagradas da angústia existencial, deslocou-se de forma expressiva para a órbita do lúdico, mesmo em meio a estrutura dos códigos dos jogos constituídos pela sociedade industrial.

Os psicanalistas sublinharam que um dos primeiros jogos infantis é o esconde-esconde, ou presença-ausência. Ele trata da elaboração do estar no mundo da criança, através da presença-ausência da figura materna, que por outro lado significa também a possibilidade dela continuar vivente, dada sua precária situação de total dependência.

A condição do recém-nascido e da criança é bastante precária, e a ausência, isto é, a falta de satisfação de seu desejo, a carência, gera um verdadeiro desespero, somente aplacado pela realização através da figura materna.

Brincando de presença-ausência, a criança elabora através do lúdico o rítmo da temporalidade da satisfação e da carência, ou ainda de certa forma a experiência da euforia do viver e da depressão do morrer. Entre esses momentos, a expectativa do acaso, o fluxo do destino, a hora de cada um.

Os jogos, ou o lúdico, através do perde-ganha, ausência-presença, carência-satisfação do desejo, se constitui num teatro mundi de elaboração de angústias existenciais, englobando a ultrapassagem, ou os percalços, representações do fluxo do destino.

Os jogos com a bola, forma-ovular, ventral, enfatizam representações deslocadas da maternidade, aludem a gestação envolvendo o mistério da gênese. No Brasil, a expressão "dar bola para alguém” quer dizer dar presença, reconhecimento, disponibilidade para o outro, expectativa de satisfação do desejo.

Por outro lado, a pretensão do positivismo é a de que através da ciência se poderá controlar o acaso, ou mais que isso, a tecnologia seria a responsável pelo fim das carências. O que notamos é que, na verdade, é o fim da carência de determinados desejos de parcelas mínimas da população da terra, e o aumento do flagelo das guerras, exploração e carências da grande maioria.

Mas essa pretensão é também parte integrante do teatro mundi dos esportes, e a tensão entre as linguagens de percepções diferentes provoca novos atrativos. De um lado, causa perplexidade que o Dream Team não treina segundo as normalizações tecnicistas, e de outro lado, mais ainda, o fracasso de Bubka da CEI no salto com vara contrariando todos os prognósticos dos experts. Tendo ultrapassado mais de seis metros de altura por mais de vinte vezes, bicampeão mundial, não conseguiu no dia olímpico passar dos cinco metros e setenta centímetros. Por que?!! 
É a presença do acaso que constitui um dos encantamentos do lúdico. E porque o lúdico não é percebido como o sagrado, como algo sério que ele ocupa assim, disfarçadamente, em meio ao Estado positivista, tanto espaço, tanta atenção e reveste o quotidiano de tanta intensidade.

O futebol, assim como o basquete, e outros jogos surgiram no contexto da industrialização como forma de exercício de instauração da identidade de sujeito produtor, numa sociedade cada vez mais estratificada e especializada, dividida rigidamente em setores, porém, com o objetivo único de fabricar produtos, cada vez mais e melhor, isto é, a menores custos. Assim, esses jogos dividem as posições dos atletas exigindo melhor performance de cada um no seu setor na busca do goal, objetivo, quanto mais melhor.

No Brasil, o futebol-arte, criado pelos brasileiros, é resultado da apropriação, adaptação e transformação do esporte britânico pela tradição cultural africano-brasileira.

Nessa nossa tradição cultural, a temporalidade e a espacialidade emergem dos valores sagrados e linguagem das instituições das comunidades da tradição africana, que se realiza através da ritualização de uma visão de mundo através de uma complexa complementação de códigos e riquíssimo repertório estético abrangendo movimentos e gestos.

O pleno e o vazio, o visível e o invisível, dimensão das relações intrínsecas que abrange o mistério da interação deste mundo e do além, se interpenetram e se elaboram liturgicamente, através de uma expressão estética de profunda sabedoria constituída pelo culto aos ancestrais e às forças cósmicas que governam o universo.

O conceito nagô de Odara exprime simultaneamente o bom e o belo. O útil e eficaz não está dissociado da beleza e do sentimento, o técnico e o estético são expressões únicas.

É da riqueza da nossa tradição-africana que se desdobra a capoeira, que é misticismo, é luta, é dança, é música, é jogo. Ela compreende, sobretudo, concepções de golpes e movimentos que envolve as dimensões do visível e do invisível, do pleno e do vazio, na cadência sincopada do ritmo do mistério, da roda do tempo.

É dessa tradição que nasce a linguagem do futebol-arte, futebol-ginga. Ginga, a rainha do Ndongo no século XVII, cujos relatórios militares dos portugueses em guerra colonial-escravagista diziam ser uma guerreira invisível.

É esse futebol lúdico, a bola e o corpo, presente-ausente, esconde-esconde que proporciona o prazer do jogo descrito por Didi, Valdir Pereira, sobre o selecionado campeão do mundo em 1958 e 1962: "a gente torcia para o juiz não terminar a partida, tanto era o prazer de estarmos jogando".

É este prazer lúdico, com a cumplicidade da torcida, que explica as performances memoráveis como as de Garrincha, Manoel Francisco dos Santos, 
na seleção. Depois de driblar a defesa da Florentina e chegar cara a cara com o gol vazio, retornar para ainda driblar mais um italiano desesperado em busca da bola, e enfim encostá-la para o fundo das redes.

Dois anos antes, quando o selecionado excursionava pela Inglaterra, teve a seguinte referência "nas folhas londrinas", narradas por Mário Filho no livro O Negro no Futebol Brasileiro: “... o futebol brasileiro tem tudo de um circo: o comedor de fogo, o engolidor de facas, os acrobatas, os trapezistas, até os palhaços. Só não tinha essa coisa elementar que era um team".

Nada de admirar vindo de jornal de um império colonial industrial, em que o monumento mais significativo é um relógio...

Nesta mesma época, dentro do mesmo processo de adaptação e transformação das linguagens esportivas do mundo branco, os Harlem Globe Troters exprimiam novas dimensões lúdicas no basquete dos Estados Unidos. Imbatíveis, só não podiam competir na Olimpíada...

Hoje, porém, a conquista de novos espaços sociais da comunidade negra permitiu a performance do Dream Team, o Time dos Sonhos na Olimpíada.

Para nós não é difícil reconhecer a fonte de sua eficácia e beleza, swing e ginga são conceitos similares, emergem do riquíssimo repertório de movimentos e gestos das culturas e tradições africanas nas Américas.

Movimentos sincopados, que operacionalizam dimensões do visível e do invisível, ausência-presença, na cadência que se interrompe dando lugar ao vazio para reaparecer em ato num tempo forte.

O sagrado inspirando o lúdico, o mágico, o deslumbramento, o encantamento, derrubando os limites das percepções lineares das performances positivistas, o óbvio ululante como diria Nelson Rodrigues.

A variedade de movimentos, esconde-esconde, da equipe brasileira de volley masculino se aproximou desta dimensão lúdica da ginga e do swing.

Por um momento, com a participação da torcida, a paixão compartilhada de uma identidade nacional se fez sentir.

Por outro lado, não foi à toa que o cineasta africano-americano Spike Lee abandonou a torcida pela equipe de volley dos EUA e veio somar-se a nossa.

Alianças forjadas e sonhadas no sentimento e na paixão de emoções estéticas comuns em torno do lúdico, emergente das dimensões sagradas de um contexto civilizatório pan-africano-americano, principalmente para nós na Bahia, onde, como disse Muniz Sodré, nossa pólis não é grega, é negra, Dream Team. 



\section{A PASSOS DE POMBO, O JOGO DA LIBERDADE}

A Coexistência da Diversidade Humana

No alvorecer do novo milênio, ocasionalmente ou não, o fluxo da História marca o aparecimento de uma nova problemática teórica nas tentativas de compreensão das sociedades humanas. Trata-se da emergência dos problemas, advindos com a coexistência de diversos povos constituintes da humanidade no contexto da chamada globalização.

Podemos caracterizar a atualidade das sociedades contemporâneas, de um lado, pela diversidade ôntica característica intrínseca da humanidade, os distintos povos que atualmente habitam o planeta, e de outro, a tentativa de univocidade de valores de culturas e de tentativa de dominação de uma aliança de povos de matrizes culturais homogêneas, os europeus, sobre os demais através, primeiramente, do colonialismo, depois do imperialismo e agora, do que se convenciona chamar de globalização.

Passada a época do colonialismo e do escravismo mercantilista, das conquistas territoriais e da exploração do trabalho manu militari, no imperialismo, o que voga é a política assimilacionista, a partir da imposição de um único modo de produção e de consumo de bens manufaturados, uma exploração do trabalho com larga margem de seduções e repressões de variados aspectos, e enfim, constrangimentos militares retráteis.

No que ora se convenciona chamar de globalização, ou o que Marshall Mcluhan chamava de "aldeia global", as formas de comunicação dos centros irradiadores do poder que constituiram outrora o colonialismo-escravista, procuram predominar sobre todas as formas das civilizações e culturas distintas e características dos infinitos povos constituintes do universo humano, e nesse processo, uma cultura do espetáculo se sobressai .

Agora, ao invés da espada e do crucifixo, símbolos da colonização, nós temos uma gama de disneylândias de toda espécie a procurar seduzir mentes assimiláveis num movimento centrípeto, em direção ao centro do poder imperial, e centrífugo, para os que sossobram. 
É como compreendemos a metáfora da escolha de Caty Freeman, atleta de "origem aborígene" da Austrália, para acender a pira Olímpica 2000, ponto culminante do espetáculo de abertura.

Depois da dramatização da lenda sobre a formação do país-colônia, Austrália, desde o encontro da menina "ingênua"celestial e colonizadora com o aborígene, passando pela "construção colonial" até as tentativas de harmonização social entre os diversos, sob um Estado nacional colonial inglês ou anglo-saxão, a metomínia da encenação mostra a pira de fogo sendo acesa numa bacia de água!! A mágica aborígene originária, o controle do fogo pela humanidade, agora pelas mãos da aborígene australiana, se transforma em magia positivista científico-tecnológica.

A bacia platinada, disco voador, tecnologia celeste, segue seu destino de fogaréu olímpico em direção ao cume do estádio até a erecta coluna que lembra a eternidade dos jogos sobre todos. A eternity australiana, tecnológica, globalizante ao alcance de todos que têm TV, rádio ou computador.

Até as diferenças dos fusos e "confusos" horários, sub-repticiamente lembra que todos estamos com nosso tempo esquadrinhado pelas referências do meridiano de Greenwitch na Londres metropolitana.

Através da globalização, com o predomínio das matrizes anglo-saxônicas, via EUA, o império britânico continua a predominar, diuturnamente, sem que o sol nunca se ponha em seus limites.

Mas o esquadrinhamento do tempo, o tempo produtivista da sociedade industrial se projeta também nas práticas esportivas. As modalidades se concentram em execuções de performances em menor espaço de tempo, num contexto de competitividade máxima. Mas também de qualidade de execuções e de sincronismos; sublimando o exercício das formas do processo produtivo industrial, que se conjuga hoje com a velocidade e qualidade da comunicação, o chamado mundo virtual.

Todo esse encantamento do espetáculo, tem seu lado solene. Como súditos da competição, todos ouvem contritamente os hinos nacionais e suas respectivas bandeiras sendo suspensas. Mesmo quem perde com resignado respeito, aceita a sujeição ao vencedor. Evidente que o hino mais tocado é dos EUA...

A comunicação, espetáculo em torno dos valores ascéticos do mens sana in corpore sano é homóloga às práticas produtivistas, tecnológicas, articuladas com a competitividade lúdica dos jogos, que avança na analogia com os valores ascéticos da religião protestante predominantemente anglo-saxônica.

As atividades missionárias, hoje, se desviam para uma cultura do espetáculo que tem na passividade de postura voyerista televisiva a quietude do puritanismo metodista e do panoptismo de Bentham atualizados.

A vigia e a vigília se fazem através do encantamento do reflexo narcísico caracterizado pela transferência das emoções propostas pelo lúdico; brinca-se de vencer e perder, permanecer ou ser eliminado, sublimação dos destinos de todos nós. 
Cathy Freeman agora está na pista para disputar a medalha de ouro. O estádio em grande expectativa. Ela corre para ganhar os $400 \mathrm{mts}$. Comemora com bandeiras da Austrália e a Aborígene. E declara: "-para mim são iguais ." Ufa! para os mentores de todo esse espetáculo; vitória da globalização. Mas não tanto. Uma TV mostrou ao mundo que há movimentos sociais aborígenes acampados há anos em frente ao parlamento australiano, exigindo direitos. Direitos desde a garantia de retomada territorial.

É o grilo. É o que incomoda. Nesse contexto de herança colonialescravista, financeira, mercantilista, capitalista imperialista, industrialista, a diversidade étnica emerge a cada dia exigindo respeito aos direitos coletivos dos diversos povos existentes no planeta. Um novo paradigma de ética e de direitos coletivos, tal qual a Carta dos Direitos do Homem, está para nascer, a passos de pombo para pacificação da humanidade. 



\section{MUHAMED ALI, A BORBOLETA E A ABELHA}

Muhamed Ali é considerado o maior lutador de boxe de todos os tempos por sua eficiência técnica e capacidade de ter conquistado por três vezes o título de campeão mundial. Motivos referentes ao contexto histórico em que se deu sua trajetória motivaram a perda do título fora do ringue por punições e condutas que perturbavam e contestavam as políticas totalizantes do stablishment. De um lado, a luta de busca e afirmação da identidade negroamericana e de outro, a convocação da guerra do Vietnan que ele não aceitou por motivos éticos e religiosos.

O movimento negro-americano erigiu o islamismo como fator de afirmação identitária, especificamente a facção liderada por Malcom X, e Cassius Clay aderiu, convertendo-se e renegando esse nome, para ele com as conotações do tempo da escravidão, adotando um novo que conotaria libertação, Muhamed Ali.

Essa conversão com todo o envolvimento de luta ideológica de afirmação da comunidade negro-americana causava lesões e rachaduras ideológicas num sistema anglo-saxônico puritano monogâmico como o da formação social dos EUA.

As conseqüências desta adesão aos movimentos de afirmação da comunalidade negra provocavam a reação do stablishment.

Mas o que mais ressalta na trajetória de Muhamed Ali, para nós, foi à expressão, em sua performance, dos princípios da linguagem da tradição africana, onde o que é útil, bom e eficaz está indissociado ao belo, à expressão estética.

Da arte que magnifica o sagrado das religiões negro-africanas, que tão bem conhecemos, aos seus desdobramentos estéticos a nível profano, como o jazz até a indústria cultural e, portanto, aos esportes, enfim a economia e a política do espetáculo, Muhamed Ali foi agente transformador na linguagem do boxe, até então um esporte onde a técnica objetivava basicamente atingir, pela força física, o nocaute. 
Muhamed Ali introduz na luta a dimensão do jogo, do lúdico, e da sedução que tangencia o sagrado, sua dimensão estética. Ele critica lutadores como George Foremann, grandalhão, que visa só bater e nocautear. Ele diz nas vésperas da luta com Foremann que há muito ele não escuta o anúncio de quarto, quinto, sexto, oitavo, décimo segundo round, e que com ele, irá ouvir. Porque para Muhamed Ali, a luta é jogo, é deleite lúdico e prazer estético.

Por outro lado, ele adotou a estratégia característica dos africanos desde o tempo da rainha Ginga, a rainha invisível do Ndongo, que na guerra de movimento derrotava os portugueses, e que se irradiou pelos quilombos nas Américas.

Suas esquivas combinadas com seu jogo de pernas, dança, deixavam o adversário socando o vazio. Era o encantamento de beleza da borboleta inatingível. Na primeira vez que conquistou o título derrotando Sony Liston, este deslocou o ombro socando o vazio.

Quando se apresentava a ocasião em que o adversário se descuidava, pensando estar perseguindo-o, vinham então seus golpes fulminantes, cuja continuidade de jabs anunciava. Era a hora da picada da abelha.

Era com a metáfora poética da borboleta e da abelha que ele resumia seu estilo; beleza, sedução, eficácia e prazer, trabalho socializado e mel.

Sua constante auto-afirmação de que era lindo, podemos interpretar, não se restringia apenas a seu aspecto físico, apesar de estar em evidência o lema black is beautiful que marcava o momento de afirmação de auto-estima do movimento negro, mas, sobretudo, porque ele se colocava como expressão de uma linguagem em que o belo não se separa da eficiência e se dá de forma contextualizada por ações pertinentes aos valores da comunidade.

Além de seu estilo, acrescentando ao boxe novos repertórios da linguagem, adornava suas lutas com poemas e aparições dramáticas na mídia, procurando sempre aproveitar para colocar em evidência valores de afirmação da identidade afro-americana.

Suas últimas lutas foram realizadas na África e na Ásia, forçando a mídia americana a se deslocar de seu eixo anglo-saxônico. Esta alteração é também um indíce de que é na expressão de valores das civilizações destes continentes que se alimentou, no que refere ao legado africano dos EUA, para criar sua linguagem, que o colocou no pedestal de maior lutador de boxe de todos os tempos.

Quando enfrentou a "última esperança branca", ele brincou com o lutador, infantilizando-o, como que mostrasse que diante do repertório dos valores culturais milenares africanos, a cultura branca anglo-saxônica estava engatinhando em terreno emocional eivado de hipocrisia e prepotência.

Por essa e outras lições, sobretudo de integridade e coerência com seus valores, Muhamed Ali, mais recentemente recebeu o título de Doutor Honoris Causa em Ciências Humanas por uma universidade dos EUA. 
O que queremos sublinhar e destacar é que a sabedoria que adquiriu emerge da contextualidade da comunalidade afro-americana, de seu contínuo de valores e linguagem, e que ele soube tão bem compreender expressando-o na metáfora da borboleta e da abelha, como se diz em nagô, odara pupo. 



\section{IMAGINÁRIO PÓS- MODERNO Garrincha e a Alma do Botafogo}

Em homenagem a memória de Manoel Francisco dos Santos, 25 anos de saudades.

Um dia desses assisti um depoimento do jornalista Luiz Mendes dizendo que o símbolo da estrela solitária surgiu do Botafogo de Regatas clube originário da fusão geradora do atual, inspirada no cenário dos remadores saindo na alta madrugada carregando o barco rumo à enseada se deparando com a presença da estrela Dalva, ou Vésper ou Vênus brilhando sola na infinitude celeste. A contemplação emocionada da beleza no silencio da madrugada se transforma em homenagem permanente no símbolo da agremiação.

Agora vou acrescentando, nesse momento ia-se anunciando o encontro limítrofe da noite com o dia, quando então outra estrela de muito maior grandeza, de brilho incandescente, surge no céu gerando o clarão. Da escuridão da noite nasce a claridade do dia. Desse magnífico momento que se repete eternamente surge a inspiração simbólica de representação em sucessivas listras pretas e brancas, expressando o ritmo do tempo incomensurável, mistério do existir...

“Tem coisas que só acontecem ao Botafogo"... fato que se desdobra dessa simbologia característica de sua identidade original profunda que contem a presença do imponderável, do inimaginável do inacreditável, mistério do ser.

Aspectos fantásticos dos conteúdos da noite, assombrosos mistérios se projetam em profusão promovendo o amálgama da sociabilidade do clube de competições esportivas, onde se ganha e se perde, onde se vivencia ora o jubilo da vitória ora o luto da derrota, em meio a imponderabilidade, o lúdico imitando a vida, "teatro mundi".

Por fim, mas não menos importante, é a simbologia do fogo que acompanha a natureza da agremiação. Ao mesmo tempo que é luz, brilho, 
socialidade, evolução, fertilidade, ele também pode ser destruição, consumindo-se a si próprio.

Para lidar então com essas características do destino do clube só procurando compreender e tentar dialogar e controlar as forças invisíveis que atuam e acompanham os jogos, o que Nelson Rodrigues chamou de Sobrenatural de Almeida.

Logo na entrada da sede há um altar com a imagem de N. Sra. da Conceição, associada a Oxum Mãe Ancestral suprema na religião afro brasileira. O numero sete corresponde as mães ancestrais.

Foi nessa ambiência que o Botafogo abrigou seu mais excelso dirigente, Carlito Rocha envolto na mítica de suas superstições. Com ele o famoso cachorro Biriba, animal com poderes fascinantes capaz de promover vitórias memoráveis com sua presença mística durante as partidas. Biriba é o nome de uma árvore da qual se extrai o ramo do qual se faz o arco do berimbau. Nasce para olhar e proteger, bi ri gba em língua yoruba.

Nilton Santos é quem conta numa reportagem, que certa vez Carlito Rocha deixou cair açúcar na roupa numa refeição. Acontece que o Botafogo goleou naquele dia. De aí em diante, disfarçadamente derramava açúcar na roupa em dia de grandes jogos. Um dia, um puxa-saco tentou limpar, ah... Foi demais, pra nunca mais.

Que outro clube poderia acolher Heleno de Freitas e torná-lo ídolo com todo seu temperamento e seu comportamento para além da tênue fronteira da normalidade.

Que outro clube estabeleceria a tradição de uma galeria de goleiros negros desde a época de Osvaldo Baliza; e ainda acolheu um técnico negro que teve o humor para receber Garrincha, uma dádiva do futebol, depois dele já ter sido rejeitado em outros clubes. Dizem que assim comentou Gentil Cardoso na ocasião:

-"Quando o time vai mal até aleijado aparece para fazer teste. Deixe treinar contra o Nilton Santos..."

Foi então que o gênio se revelou. Contam que Nilton Santos apelou:"contratem já esse homem, quero vê-lo sempre do meu lado". Garrincha vestiu e consagrou a camisa sete, então pai de sete filhas...

Garrincha é o maior ídolo do Botafogo, não só por ter sido um dos maiores jogadores de futebol de todos os tempos, mas também por sua singular trajetória, totalmente improvável de sucesso, da cabeça aos pés passando pelas famosas pernas, contrariando totalmente os paradigmas ideológicos do esporte do Estado burocrático positivista, produtivista tecnológico e sua medicina.

Garrincha foi quem melhor expressou a alma botafoguense, tanto pelo encantamento de sua atuação nos jogos como por seu pensamento, uma linguagem de valores mágico poético para muito além da calistênia. 
Contam que certa vez que o técnico Zezé Moreira, cansado de mandar que o ponta direita passasse logo a bola, colocou umas sebes (obstáculos de corrida do atletismo) ao longo do espaço de atuação. Depois do treino, indagado por um repórter Garrincha respondeu:- No jogo não vai ter isso.

Famosa também é a tirada de Didi, resistindo às imposições das tais comissões técnicas, acusado de não gostar de treinar:- "Jogo é jogo treino é treino.".

Era o conflito de valores entre a linguagem do talento constituinte do futebol arte, com o monturo ideológico desdobrado das instituições universitárias, sempre prontas em receber os discursos europocêntricos.

Para Didi desde que chegou ao Botafogo, e também na seleção brasileira a tática era uma só; se preocupar em fazer a bola chegar aos pés de Garrincha.

O Botafogo foi nesta época o time que mais jogadores atuavam pela seleção, e eles mantiveram e ampliaram os valores e a linguagem do futebol arte que caracteriza a nossa identidade, desdobrado da cultura afro-brasileira.

Neste ponto é inevitável a comparação com o Santos de Pelé, rival contemporâneo do Botafogo de Garrincha.

Enquanto Pelé vivenciava o contexto dos valores produtivistas urbano paulista na cidade portuária, contábil, aceitando o desafio de "matar um leão por dia" para provar a supremacia de seu talento, o melhor do mundo de todos os tempos, com a eficiência comprovada pelas aferições estatísticas, Garrincha convivia com a mata, caça, caçador, pescador da Raiz da Serra na Pequena cidade de Pau Grande. Ele vivia a temporalidade lânguida da roça, da passagem das águas e das luas em céu estrelado despreocupado com os números que regem a vida urbana industrialista.

O Rio de Janeiro, com suas belezas naturais abriga uma atitude de contemplação estética permanente, que acolhe e integra a cultura afro-baiana que enleva a alma carioca e torna-se o território próprio do futebol arte.

Se Pelé com o time (team) do Santos usava do talento do futebol arte para investidas sempre dirigidas em direção ao objetivo de fazer gols, Garrincha e o time (time) do Botafogo paravam o estádio para deleite da arte e da alegria das torcidas. Isso não quer dizer que se abdicasse das vitórias e dos títulos, mas a excelência do talento podia se dar a esse luxo.

Essa diversidade de valores muitas vezes provocava sérios conflitos, como aconteceu com a comissão técnica da seleção do Mundial de 58. Num momento do jogo treino contra a Fiorentina, Garrincha depois de driblar os zagueiros e o goleiro volta da linha do gol para driblar mais um desesperado e só depois empurrar a bola pra dentro. O técnico paulista, o "oriundi" Feola não admitiu, barrou o atacante.

A linguagem do futebol arte que constitui a excelência de nossa identidade triunfante mundo afora muito deve ao Botafogo e seus jogadores, inclusive foram eles que criaram o "olé". Realizando durante um jogo já vencido o "bobinho" no México, a torcida surpreendida e atordoada se manifestou 
como se numa tourada estivesse. Temporalidade lúdica preenchida pelo deleite do talento, da brincadeira, da alegria.Time is not only money.

Didi sublinhou a importância do prazer de jogar:- na copa de 58 "torcíamos para que o jogo não acabasse.".

Nilton Santos, compadre de Garrincha, se referiu que quando jogava tinha tudo e um pouco mais... Jogava bola, que era o que mais gostava de fazer ,morava no clube, ia a praia ver as paisagens e, ainda pagavam por isso.

Conhecido como a "Enciclopédia do futebol" considerado um dos melhores zagueiros do mundo em todos os tempos, nunca deixa a simplicidade se afastar dele.

Outro dia num depoimento na TV, contou um episódio em que jogou numa seleção do lado de Pavão, cujo estilo era de limpar a área espanando as jogadas. Já ele possuía uma jogada característica, observando a sombra do atacante vindo disputar o lance, deixava a bola transar entre suas pernas uma, duas vezes deixando sem rumo o adversário. Nesse dia porém, nessa hora Pavão entrou na jogada chutando tudo. Ainda se levantando falou: “oh cara, só sei fazer isso e você ainda me atrapalha!”.

Para destoar dessa dimensão "romântica" de valores pós-modernos devo me referir ao personagem Quarentinha, que na realidade foi o maior artilheiro de todos os tempos do Botafogo. Fazia gols de todo jeito, chutava muito forte, dava voleios ou meia bicicleta sensacionais, jogada que anos mais tarde consagrou Bebeto também saído do Vitória da Bahia terra da capoeira. O que incomodava no jeito de ser de Quarentinha era que não comemorava seus gols. Quando perguntado respondia displicentemente:-"eu ganho pra isso".

Garrincha aqui e ali "pegava no pé" de Quarentinha.

Contam que na copa de 58, o psicólogo da comissão técnica desaconselhou o aproveitamento de Garrincha baseado no teste em que desenhou um homem como um boneco de enorme cabeça. Preocupado com a situação que prejudicaria enormemente o Brasil, Nilton Santos indagou o porquê do desenho. Ele respondeu:- "desenhei o Quarentinha".

Contam ainda que numa das vezes, que foram alertá-lo que um zagueiro adversário não admitiria ser driblado por ele e que iria pará-lo de qualquer jeito, ele falou aos interlocutores: “- não tenho medo de nada”....aliás só de uma coisa eu tenho medo... Fez-se um suspense.

"-Medo de que Garrincha"?

-Medo de dormir no quarto da concentração com o Quarentinha e acordar de cara com ele...".

Entendamos essas passagens como conflitos de valores do cotidiano contemporâneo atravessado pelos processos modernos/pós-modernos ou ainda de acordo com o pensamento de M. Maffesoli, a oscilação pendular do "sprit du temps'”. Ora em direção a predominância de valores Prometéicos ora em direção a predominância dos valores Dionisíacos. 


\section{O ÔNIBUS E O ATABAQUE: PARA ALÉM DE "RAÇA" E "CLASSE"}

O filme Todos a Bordo, de Spike Lee, sobre um ônibus que atravessa os EUA levando em excursão um grupo de homens negros para a marcha de "um milhão de homens", liderada por Farrakan, que procurou demonstrar a pujança da união de significativa parcela da população americana pela luta de conquista da plenitude de seus direitos civis, nos leva também a viajar pelos caminhos da elaboração da vida social contemporânea.

O que nós podemos elaborar no meu modo de pensar, é que a mensagem que o filme nos traz é de que essa união não pode ser realizada a partir dos paradigmas sociológicos ou antropológicos que se projetam desde o século XIX, para a atualidade, centrados nas categorias de "raça" e "classe ", no caso específico aplicados à chamada "população negra" ou "povo negro", ou ainda "afro-descendentes".

Tanto um conceito quanto o outro se esvaem na medida que os personagens do ônibus vão revelando suas referências identitárias conscientes e que marcam seus interesses na dinâmica social, embora todos negros, aparentemente. "Oh! Quão dessemelhantes!!!"

Essas dessemelhanças se constituem em abordagens características da vida metropolitana em um país industrial imperialista como os EUA. Assim é que conflitos de gerações, de gênero, de valores voltados para a mobilidade social e individual, incluindo a competição exacerbada, a ideologia do conforto, o narcisismo alimentado pela cultura de massa, estão presentes na viagem do ônibus.

Alguns personagens das tramas que colocam em cena a discussão dessas temáticas são assim constituídos : Primeiro, um pai que traz o filho acorrentado a sua cintura para ser super vigiado, temendo sentença judicial que lhe ameaça retirar o pátrio poder caso o menino adolescente reincida em delinqüir. Para um e outro, a "marcha" é encarada de modo completamente diferente, e vai 
se distanciando dos objetivos a medida que o principal é superarem aquela situação. Numa brecha, o menino foge, e é recapturado somente com uma dramática declaração de amor em que se refaz o laço verdadeiramente humano entre pai e filho...

No segundo caso, uma briga envolvendo relações homossexuais entre dois dos viajantes acaba gerando um confronto de violência física e toda sorte de comportamentos estereotipados machistas, percorrem as discussões que se processam entre os que estão a bordo. Somente o emergir da condição humana de cada qual supera o estigma e a estereotipia.

O terceiro, mostra a presença do mundo encantado da mass mídia que fascina um dos personagens que pretende vir a ser um ator famoso. Já adotando essa máscara de grande artista, procura se constituir como o "melhorzinho", tentando contagiar todos enquanto a marcha...

Por fim, o quarto caso, mas não o último, é o personagem de um senhor que pega o ônibus no caminho. Comerciante de automóveis bem sucedido, divulga sua estratégia de vendas de acordo com o perfil do consumidor negro. Seu interesse na "marcha" é a divulgação de seu negócio. Sua "pose", e seus interesses declarados geram uma revolta entre os demais contra ele, que é largado num posto do caminho, e o ônibus segue...

Todo esse entulho ideológico do sistema que alimenta interesses e a identidade dos personagens dão ritmo e dramaticidade a trama e jogam no lixo quaisquer pretensões de unidades baseadas nas noções de raça ou de classe.

As idéias de raça e classe só aparecem ou se reconhecem de modo reativo quando acontece a discriminação, isto é, na seqüência em que o ônibus é parado pela polícia rodoviária e as cenas mostram a tensão diante dos policiais brancos.

A reação oriunda de uma ação desde fora sobre um grupo heterogêneo, não opera uma aliança homogênea promovida pelas noções de raça e classe que são, na verdade, exógenos ao léxico e ao repertório da comunalidade tradicional afro-americana em geral.

Em outro filme, Faça a Coisa Certa, Spike Lee brinca e ironiza com a situação de um comerciante asiático do Harlem que, em meio a uma revolta, vendo sua loja ameaçada, sai gritando para os revoltosos que ele não é branco, é negro também...

No ônibus, um motorista judeu não consegue estabelecer elo de aliança de cumplicidade com o grupo viajante simplesmente por chegar também a sofrer a discriminação. As diferenças de identidade alimentadas pela história, pela cultura, religião, fazem com que deixe o ônibus...

Se as noções ideológicas de raça e classe são equivocadas, falseadoras e, sobretudo, inoperantes para estabelecer uma rede de alianças entre os membros de uma comunalidade e incapazes de conter a tendência de anomia gerada 


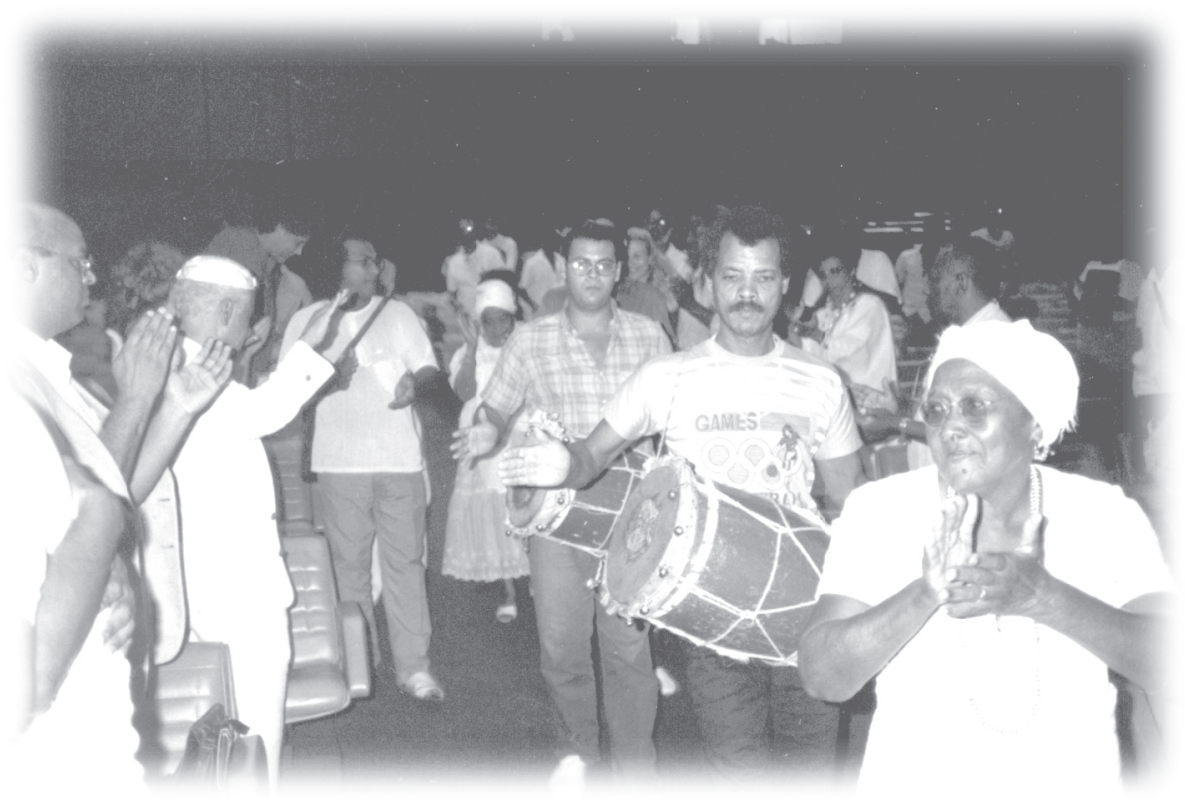

10 - Atabaques Bata do Sítio do pai Adão (PE), presentes no Congresso do INTECAB sobre a tradição e cultura Afro-brasileira, Salvador, BA - foto M. A. Luz, 1988

pela presença contextual adversa da cultura e organização social anglo-saxônica que se opõe a continuidade de civilização negro-africana e quaisquer outras, como então conseguir estabelecer as bases de uma possível união?

É aí que vem dos mais antigos a indicação do caminho que possa cessar a tensão e o conflito entre aqueles que subiram no ônibus, mas dado a sua inserção no contexto da sociedade americana, sucumbiram em meio a seus valores e se dilaceraram em meio à angústia do viver sob a égide de um sistema extremamente opressivo, disfarçado de mundo livre, mas que hoje, todos já sabem, livre para os opressores...

Um senhor de idade que conta sua história de inserção e exclusão do sistema, uma história banal, primeiro de sujeição voluntária e depois de revolta pela injustiça de um sistema que usa, abusa e joga fora ... mas que aqui, no ônibus, ocupará o espaço de personagem principal. 
Sua experiência é a trajetória de quem exauriu os limites de possibilidade de realização de sua humanidade no âmbito do sistema. Ele percorreu os caminhos possíveis, presenciou a história e ali estava só, todavia trazia consigo e o acompanhava um pequeno atabaque...

Aos poucos, o atabaque emerge como elo de ligação com os mais jovens. Um deles, começa a experimentar tocá-lo. O senhor ensina como tirar o som, os toques...Vêm as músicas, lembranças e legados ancestrais.

Fonte de comunicação de comunicabilidade, da comunalidade africana na América, tão censurada e reprimida por um sistema anglo-saxônico, puritano e imperialista ... Lá estava ele redivivo, o atabaque.

O senhor tomado pela emoção da situação que promove a coesão e comove a todos, e que puxa pela humanidade de cada um, compartilhando o fluxo de continuidade da tradição atravessando passado, presente e futuro dos afro-americanos simbolizados pela presença do atabaque, sente o coração ... Foi como se sentisse que havia cumprido finalmente sua missão; transmitindo sentido e força para a possibilidade de união entre os diversos seres do ônibus de um milhão de homens e muito mais...

Quando é internado no hospital e realiza sua viagem, o grupo está pouco interessado na "marcha" para qual se propuseram. O destino os leva para um existir maior, impulsionado pela pulsão de sociabilidade marcada pela elaboração de mundo que na tradição africana se expressa, sobretudo, pela presença de uma estética que tem no seu âmago a música percurssiva.

No final, nós que participamos da tradição afro-brasileira, sabemos que graças a continuidade civilizatória podemos dizer a partir da comunalidade religiosa, que já sabíamos deste fator de união, pois basta recordar que o lugar do atabaque sacralizado é de fundamental importância na dinâmica litúrgica, onde é saudado respeitosamente por todos os sacerdotes e sacerdotisas, autoridades e fiéis presentes, reconhecendo o seu poder e magnificência.

Para além dos limites do sistema representado pela estrada, pelo ônibus, pelo racismo e exploração e pela marcha nos seus limites, esta outra territorialização, a comunalidade afro-americana é representada pelo atabaque.

Sem dúvida, é ele e as mãos de quem toca e todos que estão unidos a sua volta expressando as mensagens que extrapolam a dimensão consciente do existir tangenciam e promovem a ligação entre esse mundo e o além que o torna uma imagem da fonte da pulsão de comunalidade, de sociabilidade da humanidade originária que se une para pensar e elaborar compartilhadamente o mistério dos destinos da existência envolto em expressões de conhecimento e sabedoria. 
Sobre os assuntos tratados, fazemos algumas indicações que poderão oferecer ao leitor outras fontes de informação.

Com referência à modernidade, indicamos os livros de: Frei Bartolomé de Las Casas, O Paraíso Destruído, a sangrenta história da conquista da América espanhola, L e PM, 1984; Dee Brown, Enterrem meu coração na curva do rio, Melhoramentos, 1986; Tzvetan Todorov, A Conquista da América, a questão do outro, Martins Fontes, 1983; Max Weber, A Ética Protestante e o Espírito do Capitalismo, Pioneira, 1985; Michel Foucault, Vigiar e Punir, Vozes, 1984; Muniz Sodré, A Máquina de Narciso, Achiamé, 1984.

Sobre pós-modernidade, indicamos os livros de Michel Maffesoli, dentre os quais: Lógica da dominação, Zahar, 1978; O Conhecimento Comum, Brasiliense 1988; O Tempo das Tribos, Brasiliense, 1990; A Sombra de Dionísio, Graal, 1985; A Conquista do presente, Rocco, 1984. Indicamos também o livro organizado por Heloísa Buarque de Hollanda, Pós-Modernismo e Política, Rocco, 1991.

Sobre cultura negra, relacionamos Cheik Anta Diop, Civilisation ou barbarie, Presence Africaine, 1979; Juana Elbein dos Santos, Os Nagô e a morte, Vozes, 1976; Deoscoredes M. dos Santos, História de um terreiro, Max Limonad, 1988; Marco Aurélio Luz, Cultura negra e ideologia do recalque, Achiarné, 1983 e como autor e organizador, Identidade Negra e Educação, Ianamá, 1973; Elisa Nascimento, Pan-Africanismo na América do Sul, emergência de uma rebelião negra, Vozes, 1981; Mário Filho, O negro e o futebol brasileiro, Civilização Brasileira, 1964; de Muniz Sodré os livros, À verdade seduzida, Codecri, 1983, Samba o dono do corpo, Codecri, 1979, e O terreiro e a cidade, Vozes, 1988. 



\section{DADOS DO AUTOR}

Marco Aurélio de Oliveira Luz fez seus estudos no Colégio Pedro II, 181 formou-se em Bacharel em Ciências Jurídicas pela UFRJ, cursou o Doutorado em Direito do Trabalho na UFRJ. Bacharel e Licenciado em Filosofia e Ciências Humanas pela UFRJ, e Mestre e Doutor em Comunicação pela UFRJ. Fez curso de Pós-Doutorado na Université de Paris V, Sorbonne. Foi professor Assistente da UFF e da UERJ e professor Adjunto da UFRJ. Atualmente é Professor Adjunto da UFBA.

Membro fundador e integrante das diretorias da Sociedade de Estudos da Cultura Negra no Brasil - SECNEB, da Sociedade Cultural e Religiosa Ilê Asipá e do Instituto Nacional da Tradição e Cultura Afro-brasileira - INTECAB. É escultor e escritor, autor do livro Cultura Negra e Ideologia do Recalque, Agadá, Dinâmica da Tradição Africano-brasileira, Do Tronco ao Opa Exim, entre outros, e autor de vários artigos e ensaios. 
Este livro foi publicado no formato $170 \times 240 \mathrm{~mm}$ miolo em papel $75 \mathrm{~g} / \mathrm{m}^{2}$

tiragem 300 exemplares Impresso no Setor de Reprografia da EDUFBA

Impressão de capa e acabamento: Cartograf. 